\title{
CAUGHT IN-BETWEEN
}

The Impact of Different Forms of Mandated National Assessment for Qualifications on Teacher Decision-Making in

Year 12 History in New Zealand, 1986-2005

By

\section{GREGOR JAMES FOUNTAIN}

\author{
A thesis \\ submitted to the Victoria University of Wellington \\ in partial fulfilment of the requirements for the degree of \\ Master of Education
}

Victoria University of Wellington

2012 


\begin{abstract}
This case study takes an historical perspective to explore the curriculum decision-making of History teachers in New Zealand. It is argued that between 1986 and 2005, Year 12 History teachers were caught in-between curriculum reform on one hand, which encouraged teacher autonomy, and on the other hand, assessment reform which reduced teacher autonomy.
\end{abstract}

While teachers in this study utilised the autonomy provided by internal assessment to develop engaging class and assessment activities, they largely avoided topics in Māori, Pasifika and Women's history which were promoted through the syllabus. Factors which contributed to teachers' decisions concerning curriculum topics included teachers' perceptions of the nature of disciplinary History, personal interest and resource availability.

The primary focus on this thesis is an assessment of the impact of changes to national assessment for qualifications on Year 12 History programmes. It argues that mandated assessment for qualifications is the single-most determining factor on classroom practice. It is also argued that the assessment style which emerged for Year 12 History through the National Certificate of Educational Achievement disconnected History assessment from the intentions of its written curriculum which emphasised disciplinary History's underlying and interconnected process of gathering, analysing and presenting historical information. In some cases, the NCEA hindered rather than enhanced the development of a school-based curriculum at this level. 


\section{Acknowledgements}

I am very grateful for the assistance of my supervisor, Dr Mark Sheehan, whose encouragement, guidance, advice and critique have been most beneficial. My father, Ron Fountain also assisted significantly by proof-reading the final transcript and suggesting areas in need of pruning. I greatly appreciate his advice concerning the format, style and prose of this thesis.

I researched this thesis, while continuing my day job as Deputy Principal at Wellington College and wrote it during Term 3 and 4 of 2011, while I was on study leave. I am grateful to the Ministry of Education for awarding me a 2011 Study Award which facilitated my leave and to the Wellington College Board of Trustees who supported my Study Award application. During my absence from school, several colleagues took responsibility for aspects of my job. These included Martyn Reynolds, Robert Anderson, Darrell Harvey, James Edgecombe and Stephanie Glover. Wellington College's Headmaster, Roger Moses, was also a constant source of support and encouragement.

Many educational professionals outside of Wellington College were extremely generous with their time and resources, assisting me to access information for this thesis. At the New Zealand Qualification Authority, these included Ian Francis, Michael Steer, Sue Chalmers, Veronica Young, Dave White, John Burns and Paul Andrews. I was also fortunate to be able to discuss ideas with the New Zealand Council of Educational Research's Cathy Wylie, who was Victoria University of Wellington's 2011 Stout Research Fellow, researching a topic related to my thesis. Peter Lineham, Bruce Taylor, Dominic King and Carol Jarman all provided useful documents from their files.

Fifteen teachers or education officials were interviewed for this thesis. They were Laurie Lord, Noeline Hannan, David Wood, Bruce Taylor, Dominic King, Sheryll Ofner, Sharyn Meffin, Margaret Cotter, Carol Jarman, Peter Thomas, Simon Dench, Paul O'Connor, Paul Wulff, Richard Webb and Paul Enright. The input of these busy people was integral. It is sad that Laurie Lord died in April 2011. As he played a significant role in the administration of Sixth Form Certificate, and was a leading advocate of internal assessment and quality 
assurance, I would have enjoyed the opportunity to discuss the findings of this thesis with him.

During my interviewing 'road trips' it was great to be able to stay with friends and family who provided comfortable beds, great food and stimulating conversation. Thank you to Esther Graham and Pravin Sawmy, Kathryn and lan Duggan, Suzanne Pidduck and Dave Thorp, and Christine and Andrew Harrex for their hospitality. Travel throughout New Zealand to conduct the interviews was funded by a Faculty of Education Post-Graduate Research Grant.

This thesis was caught in-between some significant events in our family. Our twin boys, Theo and Amos were born one week before I began my study leave. I am consequently hugely indebted to my partner, Haidee Westwater, and our parents, Margret and Keith Westwater and Tricia and Ron Fountain who between them wonderfully cared for the twins and our two-year old son, Jamin, during the times I was working on the thesis. I am fortunate to have such a supportive family. 


\section{Contents}

Timeline

Overview

Chapter One

Introduction

Theoretical Framework and Methodology

The Wider Context

Developing the Year 12 History Curriculum

Year 12 History Encounters Sixth Form Certificate

Year 12 History Encounters Unit Standards

Year 12 History Encounters Achievement Standards

109

Chapter Eight

Appendices

Bibliography

1. Teacher Interview Questions

135

2. Purposive Sampling Matrix

136

3. Ethics Approval

137

4. Introductory Letter

139

5. Interview Consent Form

140

6. Transcript Release Form
7. Final Approval of Selected Quotations 
Timeline

Year 12 History Curriculum and Assessment Developments 1983-2005

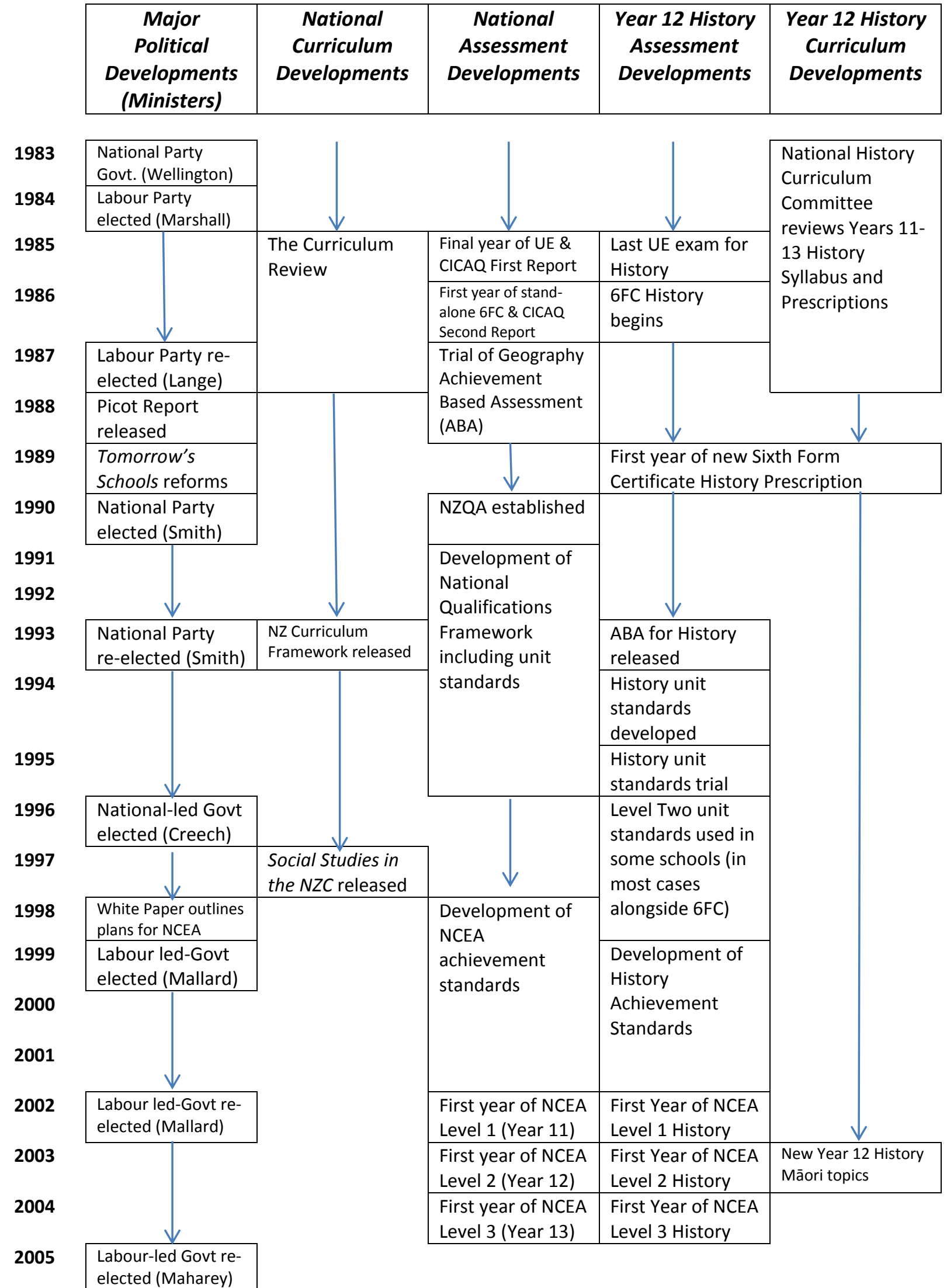




\begin{tabular}{|c|c|}
\hline $\begin{array}{c}1982-1988 \\
\text { University Entrance History (and Sixth Form } \\
\text { Certificate History 1986-1988) }\end{array}$ & $\begin{array}{c}1989-2005 \\
\text { Sixth form Certificate, Unit Standards and } \\
\text { Achievement Standards* }\end{array}$ \\
\hline 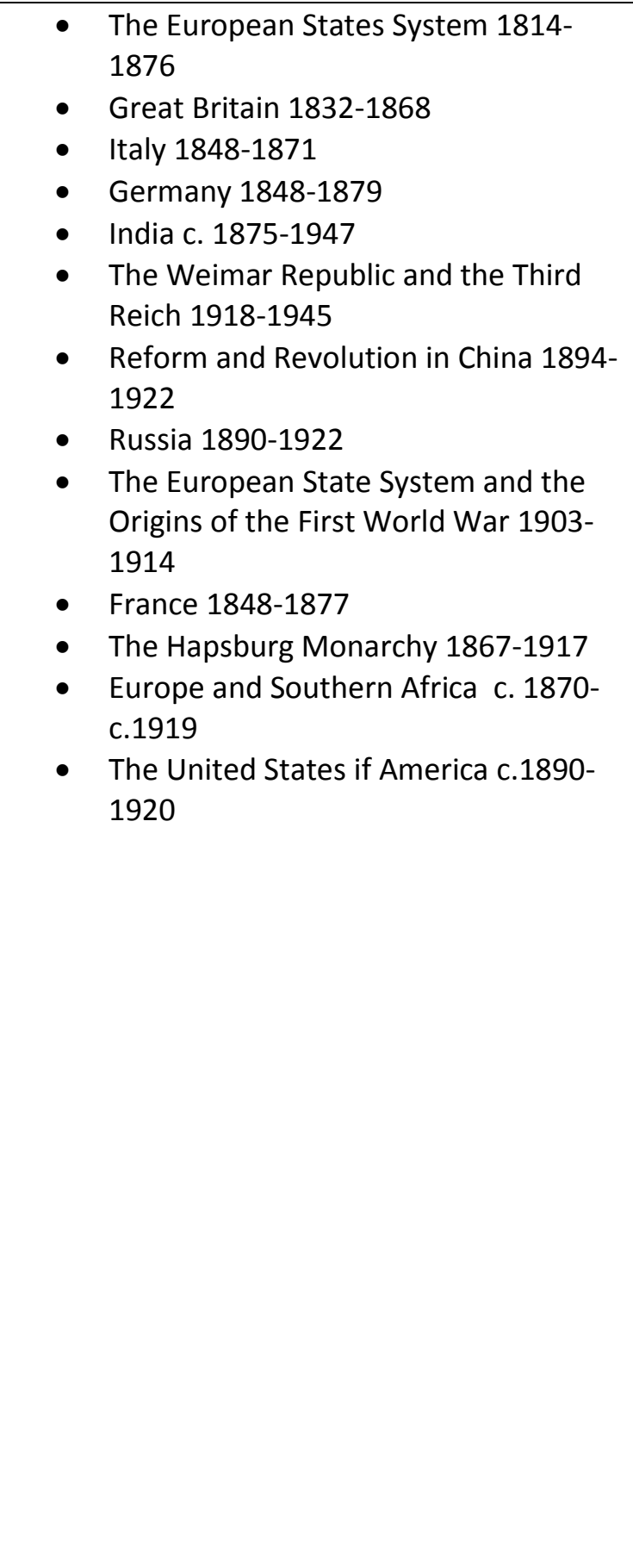 & 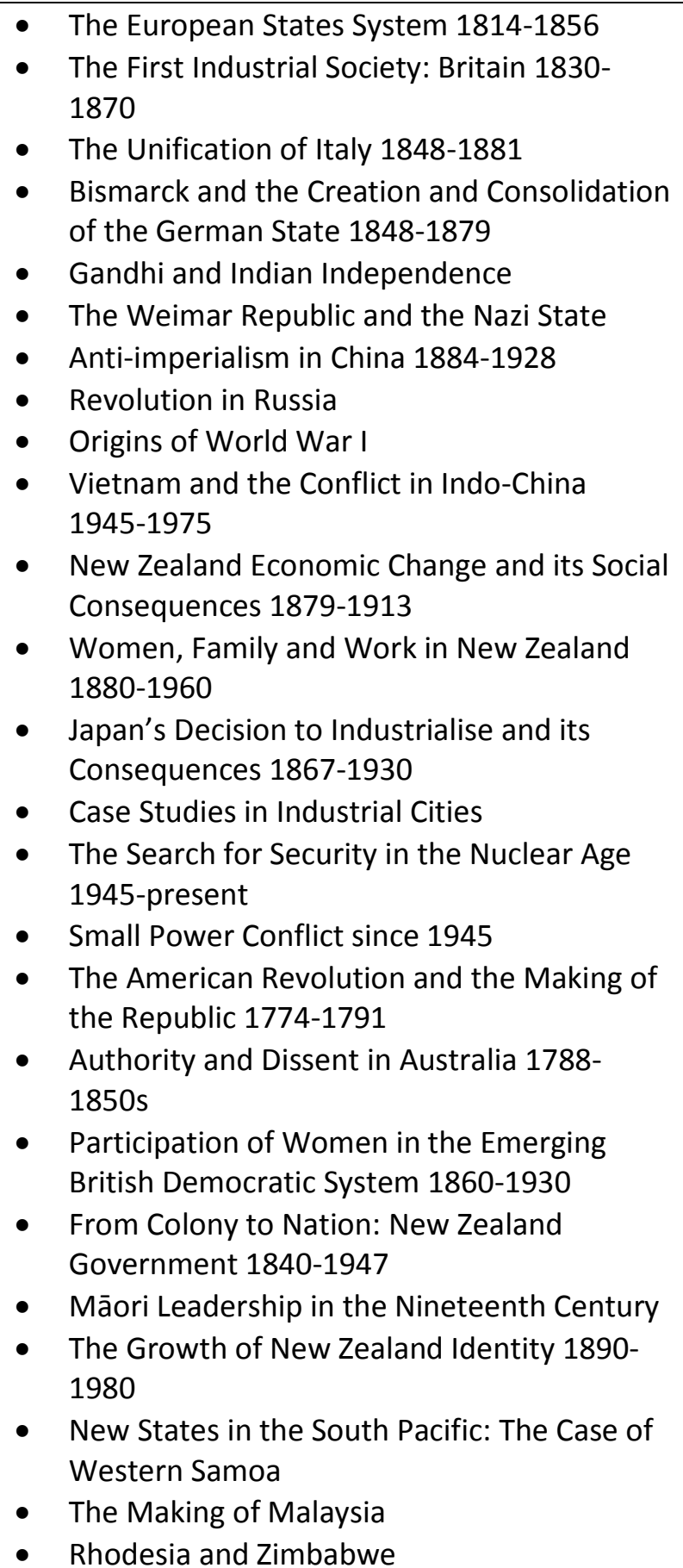 \\
\hline
\end{tabular}

'From 2003, five additional 'Māori topics' were made available for assessment against achievement standards. These were: 'Innovation and Interference: Māori Economic Activity 1816-1875'; 'Māori Participation in International Theatres of War in the Twentieth Century'; 'The Search for Political Unity: Māori Socio-Political Structures 1900-1990'; 'Tino Rangatiratanga/Sovereignty: New Zealand and the Māori Nation 1984-1999'; and 'Christianity and Māori 1814-1880.' 


\section{Chapter One}

\section{Introduction}

The national curriculum... gives schools the scope, flexibility, and authority they need to design and shape their curriculum so that teaching and learning is meaningful and beneficial to their particular communities of students. In turn, the design of each school's curriculum should allow teachers the scope to make interpretations in response to the particular needs, interests, and talents of individuals and groups of students in their classes. ${ }^{1}$

The New Zealand Curriculum, 2007

\section{Autonomy and Assessment}

This thesis is a case study of Year 12 History in New Zealand between 1986 and 2005 . It examines the basis by which secondary school History teachers, when offered a high degree of autonomy over their programmes, embraced or rejected the opportunities which were available and investigates the impact of changes to national assessment for qualifications on school History programmes over this period. By providing an historical perspective on this process, this research informs curriculum leaders, teachers and government officials concerned with the senior secondary area as they grapple with the challenges of implementing the 2007 curriculum.

It is argued that Year 12 History programmes which operated in secondary schools between 1986 and 2005 were caught in-between competing curriculum, assessment and administrative reforms. ${ }^{2}$ The Syllabus and Prescription which framed History courses at this level were developed under the auspices and assumptions of the Department of Education's Curriculum Development Division and it was expected that its implementation would be fully supported by the Department when it was introduced. However, the Department was abolished in 1989, the same year in which the curriculum was mandated for Year 12 . As a

\footnotetext{
${ }^{1}$ Ministry of Education, The New Zealand Curriculum, 37.

${ }^{2}$ This thesis develops my previously published ideas about the New Zealand History curriculum and its assessment. See: Fountain, "Caught in Between." (The article was originally submitted as part of the course work undertaken for my Masters of Education.)
} 
result the curriculum was unsupported and under-resourced. It is argued that this contributed to teachers choosing not to engage with some of the new topics and emphases of the curriculum. The thesis shows that Year 12 History teachers utilised the autonomy provided by Sixth Form Certificate's internal assessment to develop innovative and highinterest activities for their students; however, this same autonomy enabled most teachers to avoid topics in Māori, Pasifika and Women's history which the Syllabus promoted.

Senior History was excluded from the development of the new curriculum statements in the 1990s. So when major assessment reforms were introduced from the mid-1990s, the teachers and historians contracted to develop the new style of assessment for History faced the difficult task of formulating a standards-based assessment framework without an outcomes-based curriculum. Their solution was to concentrate on isolated skills from the syllabus rather than historical content. This divorced History assessment from the intentions of the written curriculum which emphasised disciplinary History's underlying and interconnected process of gathering, analysing and presenting historical information. Despite this deficiency, the unit standards trial, through its participatory model and the work of its specialist History facilitator, led to the development of a community of History teachers with expertise in standards-based task design and the assessment of student work. The unit standards faced criticism from both within and outside the History teaching community. This criticism was based on perceptions of the unreliability of internal assessment, the fragmentation of subject disciplines and the simple pass/fail grading of student work under the new system. As a result, a political compromise emerged in the National Certificate of Educational Achievement (NCEA) from 2002. The NCEA brought back external assessment for some of the standards and introduced four levels of gradation. The evidence from this study suggests that while those teachers who had benefitted from the earlier unit standards trial successfully made the transition to the internally assessed achievement standards, those who were not included in the trial found the transition from Sixth Form Certificate more difficult. Many teachers responded to NCEA internal assessment by downloading assessment tasks from external sources and removing creative aspects from their Sixth Form Certificate assessment programmes. These steps were taken to meet the requirements of the achievement standards criteria and make the administration of the NCEA manageable, but they hindered the development of a school- 
based curriculum as envisaged by the framework developers. The return of external assessment to Year 12, through the NCEA from 2003, meant that a curriculum, which was designed to be internally assessed, now had to be partially assessed through a national examination. This thesis argues that the generic approach to question-setting, by which source analysis and essay questions were asked without reference to specific topics the students had studied, was inevitable but detrimental to the teaching of disciplinary History which emphasised the development of history skills within an historical context.

This study has important implications for the present. It demonstrates that mandated assessment, especially external assessment for qualifications, is the single, most determining factor on classroom practice, far outweighing the impact of the written requirements of the curriculum documentation. This underlines the crucial importance of policy makers developing curriculum and assessment initiatives in tandem rather than in isolation from each other. With increased levels of internal assessment being introduced to the NCEA, ${ }^{3}$ school leaders need to prioritise the development of assessment-writing expertise to complement teachers' content knowledge. Since assessment dominates curriculum decisions, this expertise is crucial for the school-based vision of The New Zealand Curriculum. This thesis also suggests that History teachers are generally reluctant to engage with new content or approaches, unless they have personal interest or expertise in the proposed area of study. The availability of suitable resources for classroom use is another factor in their curriculum decision-making. Finally, through comparing the relative successes and failures of a range of curriculum and assessment initiatives, this research supports the findings of Robbins ${ }^{4}$ that successful change occurs when there is good communication between leaders and teachers, high quality education about the proposed changes, and involvement of teachers in the decision-making. These features were largely missing when the Year 12 History curriculum was implemented from 1989 and the Level Two NCEA was introduced in 2003 , although they were apparent when the unit standards were trialled in the late 1990s.

\footnotetext{
${ }^{3}$ The recent standards alignment process has led to the number of internally assessed standards increasing, with fewer achievement standards now externally assessed.

${ }^{4}$ Cited in McGee, Teachers and Curriculum Decision-Making
} 


\section{Teacher Autonomy}

The current New Zealand Curriculum ${ }^{5}$ allows for a high degree of autonomy in the senior secondary school. However, the concept of a school-based approach to curriculum design has been promoted in New Zealand before. During the first term of the Fourth Labour Government (1984-1987), a series of reviews were commissioned by the Minister of Education, Russell Marshall, which advocated a flexible, student-centred, senior curriculum in which the qualifications would be shaped around the needs of the students in each school community. $^{6}$ In particular, the First Report of the Committee of Inquiry into Curriculum, Assessment and Qualifications in Forms 5 to $7^{7}$ led to the rapid abolition of the University Entrance examination and its replacement with the fully internally assessed Sixth Form Certificate. This provided schools with the opportunity to design a teaching and assessment programme around the particular needs of the Year 12 students in their school community. ${ }^{8}$ Although a change of Minister in 1987 and a change of Government in 1990 shifted the focus of reform away from the qualifications system, Sixth Form Certificate internal assessment remained in place until the end of 2002.

Changes in the curriculum for Year 12 History also facilitated increased teacher autonomy. As it was developed during the period of Sixth Form Certificate implementation for all subjects, the revised Sixth Form History Course Statement ${ }^{9}$ (which was implemented by schools in 1989) took advantage of the absence of an externally set examination by offering a broad range of flexible topics and themes for teachers to choose from. It also provided scope for students to carry out inquiry based research projects within their own communities. Thus, the curriculum and assessment changes in Year 12 represented a major shift from the highly prescriptive model that had operated previously.

\footnotetext{
${ }^{5}$ Ministry of Education, The New Zealand Curriculum.

${ }^{6}$ Reports from these reviews include: Department of Education, First Report of CICAQ; Department of Education, Learning and Achieving; Department of Education, The Curriculum Review.

${ }^{7}$ Department of Education, First Report of CICAQ.

${ }^{8}$ The grades that a school was allocated for Sixth Form Certificate subjects were generated by the scaled marks which the cohort of students had gained in their School Certificate (Year 11) examinations.

${ }^{9}$ Department of Education, Sixth Form Certificate History Course Statement.
} 


\section{Assessment for Qualifications}

This research addresses a deficit in educational literature. Very little historical research appears to have been undertaken about assessment in the senior levels of New Zealand secondary schools - even less with a specific focus on the impact of internal assessment on teaching and learning. Most curriculum research in New Zealand has concentrated on Years 1-10, where the curriculum is mandated for all students. However, over the last 25 years increased retention has led to schooling essentially becoming a universal experience for Years 11-13 students. This study analyses the impact on History education of a series of major changes to the style of summative assessment for national qualifications across all subjects. It begins at the end of the University Entrance era in 1985 . This Year 12 qualification examined a small range of academic subjects, including History. The internally assessed Sixth Form Certificate initially sat alongside the University Entrance qualification, catering for subjects that were not externally examined. When the University Entrance qualification was abolished from 1986, Sixth Form Certificate became the sole qualification for Year 12 in all subjects. Internally assessed standards-based assessment was first introduced to Year 12 through a series of subject-based trials of unit standards in the mid1990s. The full implementation of standards-based assessment for Year 12 occurred in 2003, through the National Certificate of Educational Achievement (NCEA). Although this retained an internally assessed component, it also brought back external examinations, based on achievement standards. By exploring the impact of each of these major changes, this thesis informs current debates about the merits of the NCEA and standards-based assessment within New Zealand education.

\section{Research Focus}

The following over-arching question and sub-questions were used to guide this research:

How did the introduction of different types of mandated, national assessment for qualifications impact on the New Zealand senior secondary school History curriculum 19862005 ?

1. What was the nature and philosophical basis of the Sixth Form Certificate History curriculum? 
2. What impact did the internally assessed Sixth Form Certificate History curriculum have on teaching and learning within a Tomorrow's Schools environment (19862002)?

3. What impact did internally assessed standards based assessment (through unit standards and achievement standards) have on Year 12 History (1996-2005)?

4. What impact did the return to external assessment, through the NCEA Level 2 history examination, have on Year 12 History (2003-2005)?

5. What factors, other than assessment, affected the curriculum decision-making of Year 12 History teachers between 1986 and 2005?

\section{"Curriculum"}

As this thesis focuses on both the intended and the enacted curriculum, it uses the term 'curriculum' in two different ways; firstly, to describe the written curriculum documentation ${ }^{10}$ and secondly, the content, skills, activities and interactions of Year 12 History classes. ${ }^{11}$ The use of the term is further complicated as Year 12 History, like many other senior school subjects at this time, did not have a single Curriculum document. Instead, the subject was directed by a broad Syllabus, ${ }^{12}$ which outlined skills and emphases to be included in History programmes, and a prescription, ${ }^{13}$ which outlined topics which could be selected for study. In most cases, the users of this research will be guided by the context in ascertaining which meaning is intended. In some places, the phrases "written curriculum", "curriculum documentation" and "History programme" are used to provide additional clarification.

\section{Outline}

This thesis is divided into eight separate chapters. The following chapter outlines the methodological and theoretical framework of the research. It explains why and how a case study methodology was adopted and documentary analysis and semi-structured interviews utilised as the primary sources of research data. It also describes the impact that theoretical

\footnotetext{
${ }^{10}$ Taba defined "Curriculum" as a "plan for learning." See: Taba, Curriculum Development.

${ }^{11}$ Cornbleth defined the curriculum as the "day-to-day interactions of students, teachers, knowledge and milieu." See: Cornbleth, Curriculum in Context.

${ }^{12}$ Ministry of Education, History Form 5 to 7 Syllabus.

${ }^{13}$ NZQA, Sixth Form Certificate History Course Statement.
} 
orientations had on the study. Chapter Three provides an overview of the historical and educational context of the thesis, identifying the factors, including decisions made by politicians that influenced the Year 12 History programme through the years of this study. Chapter Four examines the process by which the History Syllabus and Prescription for Year 12 History were generated by the National History Curriculum Committee (NHCC) in the mid-1980s and reveals ways in which the arrival of Tomorrow's Schools prevented the implementation phase of the curriculum development from being adequately completed. Chapter Five is the first chapter which investigates the enacted Year 12 curriculum, exploring the topic choices and internal assessment methods which were utilised by Year 12 History teachers in their Sixth Form Certificate programmes from 1986. Chapter Seven investigates the impact of the mid 1990s trial for History unit standards, on teaching and learning, and the impact of the trial on the History teaching community itself. Chapter Seven analyses the impact of the NCEA and its achievement standards on Year 12 History between 2003 and 2005. Finally, in Chapter Eight, some conclusions and implications are drawn which connect this historical study to the issues currently confronting History teachers and other educators. Because of the wide range of literature that has informed this study, the literature review is integrated into the chapters rather than being confined to a stand-alone section of the thesis. 


\section{Chapter Two \\ Theoretical Framework and Methodology}

To understand documents is to read between the lines of our material world. We need to comprehend the words themselves to follow the plot, the basic storyline. But we need to get between the lines to analyse their meaning and their deeper purpose to develop a study that is based on documents. ${ }^{1}$

Gary McCulloch

\section{Introduction}

This research is informed by social constructionist theoretical approach. It is also influenced by proponents of a disciplinary approach to history education. It takes the form of a case study and adopts an historical perspective. The qualitative research methods of archival and documentary analysis and semi-structured interviews with teachers and education officials are employed. This chapter justifies the theoretical orientations that shaped the research and explains its methodological approaches.

\section{Theoretical Orientation}

Locating a study such as this within a theoretical framework is an important safeguard against the research being subconsciously influenced by the researcher's own values. ${ }^{2}$ The theoretical approach of social constructionism required me to be suspicious of how the world appears, to critique the dominant structures and take a critical stance against knowledge which might normally be taken-for-granted. ${ }^{3}$ Within critical educational research, social constructionism highlights the large extent to which curricula and assessment systems are designed to reflect the values and aspirations of society's dominant elite. This is especially important in the examination of History curricula as the aspects of the past that are emphasised in school History programmes are believed to influence the ways in which citizens view the present. ${ }^{4}$ Consequently, as Apple has shown, the

\footnotetext{
${ }^{1}$ McCulloch, Documentary Research in Education, 1.

${ }^{2}$ McCulloch, Documentary Research in Education.

${ }^{3}$ Burr, An Introduction to Social Constructionism.

${ }^{4}$ Phillips, History Teaching.
} 
development of History curriculum documents throughout the western world has been a fiercely contested process. ${ }^{5}$

In this study, social constructionism provided a lens through which I could explore how knowledge and schooling are established and maintained. Teachers' ideas about History education are socially constructed. Their decisions about the programmes they teach are not derived from unquestionable principles about what aspects of the past students should learn, but from their own values, backgrounds and assumptions. The 'official' curriculum is also socially constructed. It gives status to certain types of knowledge at the expense of other types, based on a range of variables which are explored in this thesis. Mandated qualifications systems, such as internal assessment or external examinations, also prioritise skills and knowledge and reflect the assumptions, values and beliefs of governmental decision-makers. The social constructionist approach has facilitated the separation of these systems and decisions from the assumptions and values which informed them. This deconstruction when followed by reconstruction has the potential to inform future decision-making on issues of curriculum and assessment.

In his work on education policy in England in the 1980s, Ball followed a social constructionist framework for analysing the development and implementation of curriculum change, which influenced this study. Firstly, he stressed that an understanding of the ideological basis for policy was essential within what he called the 'context of influence'. Secondly, he examined the 'context of text production' - the battleground in which the education officials and selected groups of teachers produced the documentation of the curriculum. Finally, he analysed the 'context of practice' to assess the extent to which policy was implemented in classrooms. $^{6}$ For each of the major curriculum and assessment initiatives in this thesis, I analysed the new policy within its wider political and educational context, examined the construction of History curriculum and assessment documentation which stemmed from the policy, and investigated ways in which teachers responded to the new policies and frameworks through their classroom practice based on their situation and beliefs.

\footnotetext{
${ }^{5}$ Apple, Education and Power.

${ }^{6}$ Cited in Phillips, History Teaching, 6.
} 
Deng and Luke's discussion of the relationship between subject matter and disciplinary knowledge prompts curriculum researchers to theorise the school subjects which they are studying. ${ }^{7}$ This thesis has drawn on proponents of the 'disciplinary approach' to History education such as Shemilt ${ }^{8}$, Sexias ${ }^{9}$, Lee and Ashby ${ }^{10}$ who discuss the nature and status of historical knowledge as a rational construction of the past that is informed by evidence. History provides a structure of disciplinary thinking which, sometimes unconsciously, influences the decisions of curriculum developers to prioritise certain types of knowledge for students. Through senior secondary school History courses, especially those in Years 12 and 13 , teachers induct students into the discipline, helping them to develop a framework of historical thinking which enables them explain the world that they live in.

In this study, an understanding of the disciplinary nature of History curriculum decisionmaking at both national and classroom levels, revealed that historical topics, especially those derived from European settings with a substantial historiography, were prioritised as being 'real history.' This perception had an impact on the university historians and teachers who shaped the curriculum, on the teachers who made topic selections within it, and on the students, who in some schools resisted the introduction of topics in women's, Māori and Pacific history, which were seen to have lower status than established topics.

At the same time, the idea that a school curriculum should reflect the structure of its parent discipline, combined with humanistic and progressive child-centred approaches to education, ${ }^{11}$ enabled the successful introduction of student research components to History courses. As well as prioritising the transmission of certain types of subject knowledge, an understanding of disciplinary thinking highlighted the process by which academic historians interpreted historical sources and constructed historical arguments about the past. As school History programmes were derived from the academic discipline, it was logical that students be given the opportunity to conduct their own historical inquiries, utilising the same methodology as historians.

\footnotetext{
7 Deng and Luke, "Subject Matter," 66-87.

${ }^{8}$ Shemilt, "The Devil's Locomotive," 1-18.

${ }^{9}$ Sexias, "Mapping the Terrain," 22-27.

${ }^{10}$ Lee and Ashby, "Progression in Historical Understanding," 284-305.

${ }^{11}$ Deng and Luke, "Subject Matter," 66-87.
} 
This thesis examines the impact of different types of assessment (internal, external and standards-based) on disciplinary History. As summative assessment modes were nationally mandated for all subjects irrespective of their disciplinary background, and these had a major impact on teaching and learning in the senior secondary school, tensions inevitably emerged through which the discipline pointed the learning in one direction and the assessment mode pointed it in another. An understanding of the disciplinary nature of school subjects has underlined this tension between curriculum and assessment, which is the key theme of this study.

\section{Case Study}

This research provides a case study of Year 12 History curriculum and assessment between 1986 and 2005. Berg has defined a case study as "a method involving the systematic gathering of enough information about a particular person, social setting, event or group to permit the researcher to effectively understand how the subject operates or functions." ${ }^{\prime 2}$ He explains that by concentrating on a specific group or a single phenomenon, researchers aim to discover how different factors interact with each other. An additional feature of case study methodology is that it enables the researcher to "capture various nuances, patterns and more latent elements that other research approaches might overlook."13

Although this case is singular in that it focuses on one level of one subject over a specified period, it has many components. Stake points out that each subsection of a case study usually has its own context and that an understanding of each context is required if the relationships within the case study are to be understood well. ${ }^{14}$ Changes to curriculum and assessment do not occur in a vacuum. ${ }^{15}$ A feature of this research is the analysis of changes to curriculum and assessment and their impact on teachers' decisions within the cultural, political and social issues of their time.

\footnotetext{
${ }^{12}$ Berg, Qualitative Research Methods, 283.

${ }^{13}$ Berg, Qualitative Research Methods, 284.

${ }^{14}$ Stake, "Qualitative Case Studies," 442-66.

${ }^{15}$ McCulloch and Richardson, Historical Research in Education Settings.
} 
Case studies are often categorised as being either intrinsic or instrumental, but there is no strict boundary of distinction between the two. ${ }^{16}$ This study has some intrinsic value as it will be of particular interest to teachers, researchers and policy makers involved with History education, but it is primarily an instrumental case study which aims to facilitate understanding of curriculum and assessment issues across subject disciplines and periods of time.

The advice of Yin for researchers investigating case studies informed the methodology of this project. Yin stresses the importance of an inquiring mind and a willingness to constantly question why something appears to have happened. ${ }^{17}$ Throughout the study, I found both the formal supervision sessions and informal discussions with teachers, education officials and other researchers provided me with the opportuity to continuously speculate, test ideas and adjust my thinking. My training in the discipline of History included the use of historical documents in research. Documentary data combined with information gained from semistructured interviews enabled me to fulfil Yin's criterion that case study researchers assimilate large amounts of information from a wide variety of sources. ${ }^{18}$ Yin also emphasises the importance of having a thorough understanding of the issues so that he or she can interpret and react to the data appropriately. ${ }^{19}$ As I have taught History in four different secondary schools since 1995 and been involved in leadership of the subject at a national level, I was familiar with the issues which arose from this work. Yin suggests that a good test for bias in a case study is the extent to which the researcher is open to contradictory findings. He recommends reporting preliminary findings to colleagues, who may offer alternative explanations that require further investigation. ${ }^{20}$ । therefore presented preliminary findings from this research at SocCon 2011, the national conference of History and other Social Science teachers in New Zealand, in July 2011. ${ }^{21}$ Discussion generated alerted me to alternative interpretations and some additional sources of information.

\footnotetext{
${ }^{16}$ Stake, "Qualitative Case Studies," 442-66.

${ }^{17}$ Cited in Berg, Research Methods.

${ }^{18}$ Cited in Berg, Research Methods.

${ }^{19}$ Cited in Berg, Research Methods.

${ }^{20}$ Cited in Berg, Research Methods.

${ }^{21}$ Fountain, "Looking Back to Move Forward."
} 


\section{Archival and Documentary Analysis}

A major method for the collection of data was archival and documentary analysis. This involved extensive reading, the extraction of important points and the identification of themes from a wide range of documents. In particular, I was able to examine minutes, correspondence, curriculum and assessment documents, and circulars which are held in Archives New Zealand ${ }^{22}$ and at the New Zealand Qualifications Authority. ${ }^{23}$ In addition, I was able to access documentary material from private collections of History teachers and others involved in History curriculum and assessment developments.

McCulloch outlines "some basic well established rules that apply in appraising documents: ...authenticity, reliability, meaning and theorisation, ${ }^{24}$ which I adhered to in this research. I followed his suggested approach of verifying the author, place and date of each document. Secondly I appraised each document's reliability. This included consideration of the bias and representativeness of the document. McCulloch points out that "bias may be produced by a wide range of possible motives: to rationalise one's own actions and to discredit those of others; to support a case or to undermine it; to understate a problem or to exaggerate it." ${ }^{25}$ Webb et al. note that 'selective deposit' and 'selective survival' are two major sources of bias. Documents that survive in large numbers are likely to present official viewpoints. ${ }^{26}$ To miniminse the impact of this inherent bias, it was necessary to make use of a wide range of different types of documents, including personal papers, and other sources, such as interviews and secondary literature, which presented alternative viewpoints and interests.

McCulloch points out that the meaning of the evidence must be clear and comprehensible. ${ }^{27}$ One way in which this was achieved was through relating the text to its context. McCulloch stresses that while it is necessary to find out as much as possible from the internal evidence elicited from the text itself, "it is no less important to discover how and why it was produced

\footnotetext{
${ }^{22}$ Extensive files from the former Department of Education's Head Office were placed in Archives New Zealand in 1995 (Archive New Zealand Reference: ABEP).

${ }^{23}$ The NZQA collection also includes an extensive file of media coverage of assessment and qualifications issues which was utilised in this research.

${ }^{24}$ McCulloch, Documentary Research in Education, 42.

${ }^{25}$ McCulloch, Documentary Research in Education, 42.

${ }^{26}$ Cited in McCulloch, Documentary Research in Education.

${ }^{27}$ McCulloch, Documentary Research in Education
} 
and how it was received." 28 One example, from this research, involved the discovery of two different groups of unit standards for Year 12 History developed in the 1990s; with one group focusing on the History Prescription's themes and the other group focusing on more generic historical skills and understandings from the Syllabus. On initial examination, this appeared to be the result of the developers' desire to provide teachers with autonomy in course and assessment design; however, interviews with contractors indicated that their coexistence was the result of a compromise, designed to break an impasse which divided the committee designing the unit standards. Subsequent interviews with teachers and analysis of the History Unit Standards Assessment Guide, revealed that the thematic standards were rarely used. This example illustrates the importance of researchers considering the background and subsequent use of educational documents and testing initial assumptions about them.

\section{Semi-Structured Interviews}

Apart from document analysis, the other significant method was semi-structured interviews. Interviews with officials and contractors from the Department of Education, the Ministry of Education and the New Zealand Qualifications Authority, who were involved with History education during this time, ascertained their goals for History curriculum and assessment. Interviews with teachers who taught and assessed Year 12 History enabled me to investigate the basis for decisions about their curriculum and assessment programmes and to evaluate the extent to which the intended curriculum was enacted in classrooms. ${ }^{29}$

Semi-structured (or semi-guided) interviews have high validity as they enable interviewees to talk in depth and detail. ${ }^{30}$ I could probe areas suggested by the respondent's answers, providing rich data not readily accessible through written sources. However, this data needed to be treated carefully and cross-referenced against other sources. This is why documentary analysis was so important. For example, one interviewee said that establishing of the New Zealand History Teachers' Association (NZHTA) was a response to teacher concern over the development of the unit standards; however, a document

\footnotetext{
${ }^{28}$ McCulloch, Documentary Research in Education, 42.

${ }^{29}$ The schedule of questions used as the basis for the teacher interviews is contained in Appendix 1

${ }^{30}$ Gillham, The Research Interview.
} 
produced to assist History teachers with the Achievement Based Assessment criteria indicates that NZHTA had, in fact, initiated this earlier initiative at their inaugural national meeting. This example underlines the importance of cross-referencing interview data with other sources.

Fontana and Frey have shown that interviewing is not simply a neutral exchange of asking questions and getting answers. They draw on the work of Scheurich who observed that the interviewer is historically and contextually located and carries conscious and unconscious biases and motives. ${ }^{31}$ This was a particular danger given my professional background in History education at a national level and my personal preference for internal assessment (over external examinations) as a mode of assessing students for national assessment and developing students' disciplinary thinking. When transcribing my first teacher interview, I noticed that one question presupposed that the interviewee shared my view. While complete neutrality is impossible, this observation caused me to alter the language of my questions in subsequent interviews.

The complexity of an interview is compounded when the subject matter is historical. McCulloch, Helsby and Knight have commented that memory, knowingly or subconsciously, can be moulded to justify the interviewee's actions in either the past or the present. ${ }^{32}$ Once again, cross-referencing of interview data with primary written material provided an important safeguard against this. Examination of the personal papers of one member of the National History Curriculum Committee provided verification of many of the recollections of the Departmental official, who coordinated the Committee and the syllabus revision. ${ }^{33}$

One strength of this research is that it analyses both written curriculum documentation and the recollections of teachers of what actually happened in their History classrooms. This approach is informed by the work of Ball, Bowe and Gold who point out that although the government relies on its teachers to deliver policy, the complex relationship between the

\footnotetext{
${ }^{31}$ Fontana and Frey, "The Interview."

${ }^{32}$ McCulloch, Helsby and Knight, The Politics of Professionalism.

${ }^{33}$ Where possible, points from the interview with David Wood were cross-referenced with Peter Lineham's personal papers.
} 
state and schools leaves scope for teacher 'ad hocery', initiative and creativity. ${ }^{34}$ In paraphrasing Ball, Phillips describes the implementation of educational policy in the United Kingdom as "cyclical, unpredictable, open to interpretation, conflict, compromise and 'slippage ${ }^{\prime \prime \prime 35}$. The notion of 'ad hocery' or 'slippage' is particularly relevant to studies concentrating on Year 12 schooling in New Zealand. Year 12's tradition of internal assessment has led to more variation between school programmes than other levels, which tend to be more nationally uniform due to the constraints of external examinations. This research shows that the introduction of standards-based assessment and the return of external examinations for Year 12 students from 2003, without equivalent curriculum change, led to programmes becoming more uniform again. Like Ball and Phillips, Hargreaves and McGee have argued that in many cases the intended curriculum does not reach the classroom. While Hargreaves points to the entrenched structures of schooling and the teaching profession which reinforce the status quo, ${ }^{36} \mathrm{McGee}$ identifies the features of an educational environment in which teachers grow into 'extended professionals', assuming their place as education's "key educational decision-makers. ${ }^{37}$ Through its analysis of curriculum documents and interviews with teachers who implemented them, this study provides an opportunity for an assessment of these ideas within a New Zealand context.

\section{Purposive Sampling}

Barbour stresses that the goal of qualitative sampling is not to produce a representative sample, but to reflect "diversity and to provide as much potential for comparison as possible." ${ }^{38}$ Consequently, the teacher interviewees were selected through a process of purposive sampling. This involved the selection of participants because they had characteristics which I believed were likely to have some bearing on their perceptions and experiences. ${ }^{39}$ Purposive sampling required me to think critically about the demographics of the History teaching population and to choose the cases carefully. ${ }^{40}$ In this study, the

\footnotetext{
${ }^{34}$ Cited in Phillips, History Teaching.

${ }^{35}$ Phillips, History Teaching, 6.

${ }^{36}$ Hargreaves, Curriculum and Assessment Reform.

${ }^{37}$ McGee, Teachers and Curriculum Decision-Making, 29.

${ }^{38}$ Barbour, Introducing Qualitative Research, 53.

${ }^{39}$ Morse and Richards, Read Me First.

${ }^{40}$ Silverman and Marvasti, Doing Qualitative Research.
} 
thirteen teachers interviewed had taught History throughout the period (1986-2005) ${ }^{41}$ and also had an active involvement with either their local History teachers' association or the New Zealand History Teachers' Association. An involvement in a subject association ensured that the interviewee was not isolated from national developments. Stake recommends the establishing of a matrix to ensure that a range of cases is selected. ${ }^{42}$ For this study such a matrix ensured that overall the selection of interviewees included the widest possible range of teachers from provincial and urban and co-educational and singlesex schools of different decile ratings throughout New Zealand. ${ }^{43}$ Eight male teachers and five female teachers were interviewed. ${ }^{44}$

\section{Internal and External Validity}

Case studies gain credibility through the triangulation of descriptions and interpretations continuously throughout the period of study. ${ }^{45}$ Internal validity was established through the use of a wide range of methods to access information. Data source triangulation was achieved through the cross-referencing of interviews against other sources of information and through expert reviews of my findings. My supervisor, Dr Mark Sheehan, is an expert in this area, having taught History and researched and lectured about secondary school History teaching in New Zealand. He wrote his doctoral dissertation about the senior History curriculum and has published and presented on this area over the last seven years. ${ }^{46}$ As a History teacher myself, with an extensive past involvement in the marking, writing and critiquing of national examinations and, as a past Chairperson of the New Zealand History Teachers' Association, I have 'insider' status within the History teaching community. Although I have had to be aware of the dangers of an 'insider's perspective', I have had the advantages of being trusted by teachers and officials and having an established network of critical colleagues to discuss my findings with as they came to light. ${ }^{47}$

\footnotetext{
${ }^{41}$ One interviewee, Sheryll Ofner, is now the Principal of Selwyn College. Consequently, she was not teaching a Year 12 History class at the time of the interview.

${ }^{42}$ Cited in Silverman and Marvasti, Doing Qualitative Research.

${ }^{43}$ The matrix used can be viewed in Appendix 2

${ }^{44}$ Both the educational officials interviewed for this study were male.

${ }^{45}$ Stake, "Qualitative Case Studies," 442-66.

${ }^{46}$ Sheehan's recent publications include: "'Little is Taught or Learned"; "The Place of New Zealand," 671-91; "A Question of Bias? 176-88.

${ }^{47}$ In addition to the formal interviews and regular supervision meetings, I have had informal discussions about aspects of my thesis with: Rodney Hamel (formerly, St Paul's Collegiate School), Michael Harcourt (Wellington High School), Steve Watters (Ministry for Culture and Heritage), Cathy Wylie (NZCER/Stout Research Centre),
} 
As with most qualitative studies, external validity cannot easily be scientifically guaranteed. It is possible that another researcher, with different personal assumptions or another ideological framework, could examine the same evidence and reach different conclusions. Yin points out that a weakness of case studies is that they offer limited opportunities for generalisation and replication. ${ }^{48}$ To minimise these limitations, I used a range of data gathering methods, theorised my research and placed it within a wider social, political and historical context. With a clear understanding of the steps which I have taken, the user of the research will be able to assess the validity of my findings. Although exact replication is unlikely, Yin has shown that high quality case study research can still generate a theoretical proposition which can be tested through cross-case comparisons. ${ }^{49}$

\section{Secondary Literature}

The literature review for this study is integrated throughout the chapters. However, it is important to demonstrate here that this thesis fills a gap within the body of research already published on the New Zealand curriculum and History education in the last twenty years.

This study contributes to the literature which focuses on the impact of reform in New Zealand education since the mid-1980s. Openshaw, who views the Picot Report and subsequent Tomorrow's Schools reforms as a culmination of liberal feminist and bicultural views which had been espoused in the fifteen years before the Report was written, ${ }^{50}$ is prominent among the historians of this period. His work and that of others (such as $\mathrm{O}^{\prime} \mathrm{Neill}^{51}$ and Wood $^{52}$ ) makes cross-curricular generalisations about secondary education in New Zealand. By focusing on the impact of administrative, curriculum and assessment reforms on just one subject, my research contributes depth to complement the breadth of the current research in this area.

Roger Moses (Wellington College), Kim Tattersall (Wellington College), lan Francis and Michael Steer (both NZQA).

${ }^{48}$ Yin, Case Study Research.

${ }^{49}$ Yin, Case Study Research.

${ }^{50}$ Openshaw, Reforming New Zealand Secondary Education.

${ }^{51} \mathrm{O}$ 'Neill, "Change and Constancy."

52 Wood, "Political Origins of the NZCF." 
This research contributes to the understanding of the New Zealand secondary curriculum during this period, but it also adds to the body of work which focuses more specifically on

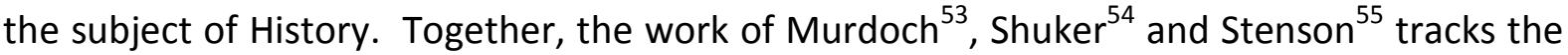
development of History as an academic subject within the senior secondary school between 1940 and 1990. Sheehan examines the process by which the curriculum documents were reconstructed in the $1980 \mathrm{~s}^{56}$ He focused solely on the development of the curriculum documentation. The major focus of this research is on how teachers translated the documentation into programmes of learning for students over the subsequent twenty years. In describing the impact of the 1980s Syllabus and the introduction of standards-based assessment for qualifications on classroom practice, this research provides the next link in the chain, updating the narrative of the development of History education to 2005 with implications for the present.

Other researchers have previously investigated curriculum-decision making in New Zealand History education. These include Manning, who lamented the lack of an iwi perspective in the teaching of History in the Wellington region and promoted a place-based approach to teaching History, ${ }^{57}$ and Derbyshire, who surveyed the teaching of New Zealand history content in schools between 1925 and $2000 .^{58}$ While Manning utilised teacher interviews, Derbyshire's work was largely based on the records from the New Zealand Historical Association. The inclusion of teacher participants in the current study, provides the dimension of the enacted curriculum, which is absent from Derbyshire's analysis. Hunter and Farthing studied the perceptions of Waikato and Bay of Plenty History teachers about the place of History within the New Zealand Curriculum, arguing that the traditional approaches and attitudes of experienced teachers prevented newer teachers from embracing a post-modern approach to History education. ${ }^{59}$ My research suggests that innovative approaches to curriculum decision-making are not the exclusive domain of the

\footnotetext{
${ }^{53}$ Murdoch, High Schools of New Zealand.

${ }^{54}$ Shuker, "History in the New Zealand Secondary School"; "Cleo in the Curriculum," 185-202.

55 Stenson, "History in New Zealand Schools," 170-81.

${ }^{56}$ Sheehan, "Defending the High Ground."

${ }^{57}$ Manning, "The Status of Te Atiawa Histories."

${ }^{58}$ Derbyshire, "Anyone's but our own."

59 Hunter and Farthing, Talking History.
} 
younger generation of teachers and that assessment for qualifications rather than curriculum and theoretical considerations determine teaching styles and content choice. While there is an emerging literature on New Zealand History curriculum matters, much of the research treats all three senior levels (Years 11-13) of the curriculum as if they were homogeneous. This gives the impression that there is a logical progression between the levels. Such a progression may reflect the intention of curriculum designers, but it does not necessarily align with the views that teachers have of the different courses they teach. This study focuses solely on Year 12, a year level which is distinctive due to its long history of internal assessment and is typically seen as the level in which students begin their induction into the discipline-based nature of the subject. ${ }^{60}$

\section{Ethical Issues}

Victoria University of Wellington's Faculty of Education Ethics Committee approved this research study prior to the commencement of the data gathering. ${ }^{61}$ An ethical issue related to this research was informed consent for the interviews. ${ }^{62}$ Prior to the interviews being conducted, participants were emailed a letter which outlined the nature of the study and provided them with an opportunity to discuss any aspect of the research either with me or my supervisor. ${ }^{63}$ The letter explained that participants would be asked to sign a consent form which provided me with permission to use the information which was generated through the interview. It was explained that they would have an opportunity to view and amend a transcript of quotations. The interviews were recorded using a digital recording device. I subsequently transcribed the interviews myself and returned the transcripts to participants for their approval. Most participants made minor changes to their transcripts, which either corrected typing or spelling errors or provided clarification of meaning. One participant made more significant amendments, but these did not alter the meaning of the

\footnotetext{
${ }^{60}$ For international research focusing on New Zealand History education, see Low-Beer, "The Eclipse of History," 113-22; Guyver, "History Curricula in England and New Zealand." Barton was also hosted by Victoria University of Wellington during his sabbatical between May and August 2009. He also conducted extensive research in New Zealand History classrooms. While he presented some of his findings at the American Educational Research Association (EARA) Conferences in 2010 and 2011, he had not published on his New Zealand material at the time this thesis was written.

${ }^{61}$ The approval letter from Dr Joanna Kidman is contained in the Appendix 3.

${ }^{62}$ Through the ethics application, the Ethics Committee approved the common historical practice of naming the interviewees.

${ }^{63}$ A copy of the letter is contained in the Appendix 4.
} 
original transcript. The final manuscript includes several direct quotations from participants. In these cases, participants were contacted again, seeking permission for their words to be used.

\section{Referencing}

It is normal for an education thesis to utilise the American Psychological Association (APA) referencing system. However, due to the prevalance of documentary and oral interview material, this thesis employs the Chicago Manual Style (Sixteenth Edition) of footnotes. As is customary in the Chicago style, short notes are used throughout the body of the text, with full information about the sources provided through the bibliography. ${ }^{64}$ Where a direct quotation is taken from a written source, a page reference (if available) has been provided. For consistency, the first initial (rather than the full first name) of a writer is used.

\footnotetext{
${ }^{64}$ University of Chicago, Chicago Manual of Style.
} 


\section{Chapter Three}

\section{The Wider Context}

The process of consultation and discussion took place in the context of widespread changes within secondary education and in the community... In secondary education, these were the review of the school curriculum, the withdrawal of the University Entrance examination from form six, and the establishment of a ministerial enquiry into senior school assessment. Changes in community attitudes included the increased consciousness of the role of women, the awareness of different cultural and ethnic groups in New Zealand society, and the growing interest in local history. ${ }^{1}$

Jim Ross, Foreword, History Forms 5 to 7 Syllabus for Schools.

\section{Introduction}

The development and implementation of the History Syllabus and Prescription which this thesis examines took place within a period of unprecedented change in New Zealand education. ${ }^{2}$ Roberts has suggested that debates over curriculum and assessment provide a window through which larger political battles can be observed. ${ }^{3}$ This chapter establishes an historical context for the analysis of curriculum change and classroom practice in Year 12 History between 1986 and 2005, which provides a lens through which larger political developments can be understood. It also shows that Sixth Form Certificate curriculum programmes and assessment for qualifications were caught in-between the political developments of the late 1980s and 1990s. While Year 12 became the testing ground for a range of different ideas in assessment during this period, the changing political and educational landscape prevented permanent change, leaving it stranded.

\section{Background}

The process by which the Year 12 History curriculum documents were developed had evolved under the leadership of New Zealand's dominant educational figure of the postWorld War Two era, Clarence Beeby. As the Director General of Education, Beeby had

\footnotetext{
${ }^{1}$ Ministry of Education, History Forms 5 to 7 Syllabus. for Schools, 4.

${ }^{2}$ For a visual summary of both national assessment and curriculum assessment reform over the period of this study, see the Timeline on page 6 .

${ }^{3}$ Roberts, "The Politics of Curriculum Reform," 30.
} 
instituted a rolling review of school subjects that involved the identification of a desire for change within a subject area by teachers or the public, followed by a series of conferences in which a recommended set of aims and principles would be established. A national revision committee, widely representative of stakeholders, would then be brought together to formulate a plan of action and generate alternative materials and new teaching approaches which would be trialled, modified and re-trialled by teachers throughout the country. There was also significant involvement of the Post Primary Teachers' Association (PPTA) throughout the process. Finally, a series of nation-wide teacher meetings would be facilitated by the Department of Education, who would also oversee an extensive offering of in-service training. ${ }^{4}$

O'Neill has shown how, for much of the post-1945 period, a bipartisan political consensus existed concerning curriculum, assessment and qualifications. ${ }^{5}$ While much has been made of Beeby's relationship with the First Labour Government's Minister of Education, Peter Fraser, it was during the period of Keith Holyoake's Second National Government that inservice training was emphasised within the Curriculum Division's work. In the 1960s, Lopdell House in Auckland and Hogben House in Christchurch were developed as residential institutions in which teachers and other participants could meet for workshops and conferences. Schools gained considerable kudos for having teachers involved in national curriculum initiatives. ${ }^{6}$

In the 1970s, the Department entered what the then Assistant Director of Education, Bill Renwick described as "a restless exploratory phase." ${ }^{7}$ Renwick emphasised the importance of developing programmes for teaching and learning which were socially relevant. ${ }^{8}$ With a strong background in New Zealand history, he also was committed to seeing the Treaty of Waitangi occupy a more central place in New Zealand society. ${ }^{9}$ Renwick's commitment to education being more explicitly owned by the local community, led him and others to question the relevance of external examinations. Indeed, as early as 1972, a group of school

\footnotetext{
${ }^{4}$ O'Neill, Clark and Openshaw, "Mapping the Field," 25-46.

${ }^{5} \mathrm{O}^{\prime}$ Neill, "Change and Constancy."

${ }^{6}$ McQueen, "Once Were Curriculum Developers," 185.

7 O'Neill, "Change and Constancy", 54.

${ }^{8}$ O'Neill, "Change and Constancy."

${ }^{9}$ D. Wood, personal interview, April 8, 2011.
} 
leaders, teachers, union representatives and education officials, meeting at Lopdell House, proposed that the Year 11 School Certificate qualification could be internally assessed. It was felt that internal assessment would allow for a wide range of skills to be assessed and provide schools and teachers with the opportunity to develop programmes of learning which were relevant to their students. ${ }^{10}$

The manner in which the Curriculum Development Division led change at this time was based on an assumption that teaching approaches, content and assessment were interrelated rather than isolated components of learning. ${ }^{11}$ In Years 12 and 13 there was at times a tension between the thrust of a new syllabus and the requirements of the examinations which were set by separate Examination Boards, but by the 1980 s it was common practice for examination board representatives to sit on the curriculum review committees. In the case of the History syllabus, Auckland University's Nicholas Tarling sat on both the University Entrance Board and the National History Curriculum Committee. He also became the University Entrance Board's representative on the Minister of Education's Committee of Inquiry into Curriculum, Assessment and Qualifications in Forms 5 to $7 .{ }^{12}$

None-the-less, the existence of the University Entrance Board which sat outside of the Department of Education, and was primarily concerned with controlling access to tertiary education, led to a complex system of qualifications existing at Year 12 level. Up till 1986, Year 12 students worked towards the University Entrance qualification as well as Sixth Form Certificate. In 1944, the First Labour Government had introduced accreditation to the University Entrance examination system. ${ }^{13}$ Students who had shown sufficient ability across their subjects throughout the course of the year could be passed by their schools without being required to sit the examinations. The only quality assurance mechanism in place was that at least five per cent of the students who sat the examinations in each school were required to pass. The memories of Paul O'Connor, a long serving and leading History teacher, of the accreditation process at Burnside High School in Christchurch are typical of many in this study:

\footnotetext{
${ }^{10} \mathrm{O}$ Neill, "Change and Constancy."

${ }^{11}$ O'Neill, Clark and Openshaw, "Mapping the Field," 25-46.

${ }^{12}$ University Grants Committee, Report of the University Entrance Board.

${ }^{13}$ O’Neill, "Change and Constancy."
} 
A Sixth Form list would be generated with ranked marks from 400 to the bottom. Then the school would decide how many sacrificial victims were required to make sure that they comfortably met the five per cent threshold and then a line would be drawn. It was generally an aggregate mark of about 212 or 214 which was based on the assumption that [students with] $190 \ldots$ to 215 [marks would] provide the necessary numbers for the school to escape external scrutiny. ${ }^{14}$

Sitting alongside University Entrance, the Sixth Form Certificate was an internally assessed qualification administered by the Examinations Division of the Department of Education. This allowed for a broader range of subjects than those examined by the University Entrance Board within the Year 12 programme. David Wood, who taught History and Music at Selwyn College in Auckland in the 1970s and later worked in the Department of Education, recalled that the Sixth Form Certificate provided a great opportunity for experimental school-based courses. ${ }^{15}$ For students and teachers of conventional academic subjects such as History, which did have a University Entrance Examination, the Sixth Form Certificate had low status. Noeline Hannan from Hutt Valley High School recalls that "no one took much notice of [a Sixth Form Certificate grade] because it didn't really get any mana until it stood alone." $^{16}$

To ensure inter-school comparability, the Department of Education operated a system by which a pool of Sixth Form Certificate grades would be allocated to each school based on the results of their students in the previous year's norm-referenced School Certificate Examinations. While statistically convenient, it was a system which caused disquiet among many educators. John Craig, the Principal of Upper Hutt's Heretaunga College likened the 'group attainment level' concept to...

...being sent a set of rugby jerseys for your team for 1982 based on the physical measurements of its members in the 1981 season. And being told these are the only

\footnotetext{
${ }^{14}$ P. O'Connor, personal interview, June 28, 2011.

${ }^{15}$ D. Wood, personal interview, April 8, 2011.

${ }^{16}$ N. Hannan, personal interview, April 8, 2011.
} 
jerseys you are going to get. 'If you look hard enough you will find there is one to fit each member of your team! ${ }^{17}$

This grade allocation system became even more contentious after the removal of the University Entrance Examination in 1986, when Sixth Form Certificate stood alone and its grades consequently had a higher status.

\section{Assessment Debates}

The debate over the merits of external as opposed to internal assessment was one area where the political consensus surrounding education had begun to unravel by the early 1980s. Openshaw has shown how the increasing retention rate of students in New Zealand secondary schools led to the 'scarcity value' of the Year 11 School Certificate, which had originally been designed as a graduation qualification, being significantly reduced. ${ }^{18}$ In a similar fashion, the relevance of an externally assessed University Entrance qualification for the increasing number of Year 12 students, ${ }^{19}$ who had no intention of studying at university, came under close scrutiny.

The leadership of the secondary teachers' union, the Post Primary Teachers' Association (PPTA) was at the forefront of the campaign for increased levels of internal assessment in the senior secondary school and the transfer of University Entrance to Year $13 .^{20}$ The PPTA leadership's growing interest in assessment and curriculum stemmed from their awareness that teaching was a political activity. ${ }^{21}$ Influenced by critical theorists such as Bernstein ${ }^{22}$ and $\operatorname{Codd}^{23}$ they believed that increased levels of internal assessment would provide teachers with much greater autonomy over curriculum decisions and improve the

\footnotetext{
${ }^{17}$ J. Craig, "University Entrance to Seventh Form," R7 246 543, Archives New Zealand.

${ }^{18}$ Openshaw, Reforming New Zealand Secondary Education, 26.

${ }^{19} 9500$ students entered Year 12 across New Zealand in 1963, while 34000 entered in 1980 - Data from P. Capper, "University Entrance to Form Seven," R7 246 543, Archives New Zealand.

${ }^{20}$ For example, see: NZPPTA, Education in Change.

${ }^{21}$ Openshaw, Reforming New Zealand Secondary Education; Apple, "Curriculum Planning," 25-41.

22 Bernstein, "Classification and Framing of Educational Knowledge," 47-69.

${ }^{23}$ Codd, Harker and Nash, Political Issues in New Zealand Education.
} 
educational achievements of marginalised students. ${ }^{24}$ The PPTA's 1977 Annual Conference adopted a policy promoting the removal of the University Entrance Examination. ${ }^{25}$

The view of the PPTA leaders was not shared by the National Party Government's Minister of Education between 1981 and 1984, Merv Wellington. Wellington was a former History teacher who believed that the external examination system was "the first guarantor of excellence ${ }^{\prime 26}$ and a mechanism for holding teachers accountable:

[The] philosophy of the examination system is to reward hard work, accuracy of knowledge, logic and clarity of thought. That was my view as a marker - a view subsequently reinforced from my visits to hundreds of schools as Minister... Moreover, external exams are a test of the individual teacher. It is against his or her pupils' results that the most accurate guide is given. Without such a 'frame of reference' pupil and teacher, parent and employer would be left to wander without rudder or guiding. ${ }^{27}$

The Minister's preference for external assessment was widely shared. In 1986, Christchurch Boys' High School Principal, Ian Leggat, toured the South Island promoting Sixth Form Certificate. He observed that the public "still need to be convinced that internal assessment can be much better than a bald external examination mark."

\section{Committee of Inquiry into Curriculum, Assessment and Qualifications in Forms 5 to 7}

Leggat's observation was made within the context of a changed political environment. In July 1984, as a result of a 'snap election' called by the National Party Prime Minster, Robert Muldoon, the New Zealand Labour Party was elected to office for the fourth time. As a result, a generational shift occurred in New Zealand's political leadership. Colin James has argued that the 1984 election brought the Vietnam generation into political prominence. He argues that the new breed of politicians were 'big picture' people who aimed to

\footnotetext{
${ }^{24}$ Openshaw, Reforming New Zealand Secondary Education.

${ }^{25}$ Capper, "University Entrance to Form Seven," R7 246 543, Archives New Zealand.

26 "Statement of Hon M L Wellington for the New Zealand Times," New Zealand Times, March 18, 1984.

27 "Statement of Hon M L Wellington," New Zealand Times.
} 
liberalise what they believed to be an overly restrictive society. ${ }^{28}$ A Departmental memorandum soon after the change of Government hopefully anticipated a "number of developments which it has in mind which will affect social studies, history and geography... e.g. for the development of issues relating to women." It was suggested that additional education officers were likely to be required to cope with the extra workload. ${ }^{29}$

As we have seen, by 1984, issues relating to assessment and qualifications had become politically contentious. Like their National Party predecessors, Ministers in the Fourth Labour Government often used 'committees of inquiry' as a mechanism for bringing about change. ${ }^{30}$ Marshall's Committee of Inquiry into Curriculum, Assessment and Qualifications in Forms 5 to 7 (CICAQ) was instructed "in light of the Government's commitment to change the present requirements for University Entrance" to "consider methods of assessment in forms 5, 6 and 7, and make recommendations for the award of leaving certificates." Priority was to be given to issues pertaining to Year 12 (Sixth Form) as the Government had already announced that 1985 would be the final year of the University Entrance Examination. ${ }^{31}$ In its preliminary report, the committee recognised the widely held view that "University Entrance is an inappropriately placed examination for the majority of students in today's sixth forms." ${ }^{32}$ The Committee recommended that, "at least in the meantime," ${ }^{13}$ the Sixth Form Certificate should become the sole national award for Year 12 students. Significantly, the Committee recommended the retention of the controversial grade allocation system by which schools were allocated Sixth Form Certificate grades, based on School Certificate marks. The committee acknowledged "the strength of feeling on the issue in some schools" but "concluded that part at least of the criticism is probably based on a misunderstanding of the present method of establishing inter-school comparability and that many injustices claimed by certain schools are more imagined than real." ${ }^{34}$ Given that the Government had already made its decision concerning the removal of the University Entrance Examination and the extremely tight timeframe which they had established for this to happen, it was not

\footnotetext{
${ }^{28}$ Openshaw, Reforming New Zealand Secondary Education.

${ }^{29}$ P. Brice, "Department Memo," R7 249 865, Archives New Zealand.

${ }^{30}$ Openshaw, Reforming New Zealand Secondary Education.

${ }^{31}$ Department of Education, First Report of CICAQ, 3.

${ }^{32}$ Department of Education, First Report of CICAQ, 4.

${ }^{33}$ Department of Education, First Report of CICAQ, 8.

${ }^{34}$ Department of Education, First Report of CICAQ, 14.
} 
surprising that the recommendations from the Committee of Inquiry's First Report reflected the status quo and focused more on the implementation of the stand-alone Sixth Form Certificate than outlining a major philosophical shift.

At the same time as the CICAQ was taking submissions, the Minister's Committee to Review the Curriculum for Schools was undertaking its work. This review of the core curriculum was a much grander exercise than the review of the senior qualifications system. Wood has described it as "an immense operation, involving more of the population per capita than anything else in New Zealand's educational experience." ${ }^{35}$ Advertisements through television and other media were used to attract more than 30000 submissions. ${ }^{36}$ The two committees had met concurrently for two of their meetings in 1985 with the intention of aligning the core curriculum with the assessment and qualifications which would be used in Years 11 to $13 .^{37}$ The Curriculum Review called for a more cohesive curriculum but with greater flexibility for schools and communities to design programmes around the needs of learners. $^{38}$ The recommendations of the CICAQ outlined a qualifications system which would facilitate a similar approach in the senior school. Its Second Report proposed an achievement-based approach to assessment with three levels of achievement in Year 11, four in Year 12 and five in Year 13. For Year 12, the committee recommended that:

The form of assessment at this level should move from one which ranks students to one which is achievement based. The present nine numerical grades by which Sixth Form Certificate grades are reported should be replaced by about four grades. That is in each subject objective criteria for achievement at four levels should be stated, and training provided for sixth form teachers to judge whether the achievement of students has successfully met the criteria. ${ }^{39}$

\footnotetext{
${ }^{35}$ Wood, "The Political Origins of the NZCF," 5.

${ }^{36}$ Wood, "The Political Origins of the NZCF," 5.

${ }^{37}$ Department of Education, First Report of CICAQ.

${ }^{38}$ Department of Education, Curriculum Review.

${ }^{39}$ Department of Education, First Report of CICAQ, 91.
} 
Contrary to their earlier insistence that injustices caused by the Sixth Form Certificate grade allocation system were "more imagined than real", 40 the Committee now recommended that "in the moderation of assessment at form 6 , each subject be considered independently of others and without reference to other levels. ${ }^{41} \mathrm{~A}$ range of different moderation strategies were outlined, with the implication that the most appropriate method be selected for each subject. ${ }^{42}$

This significant shift in philosophy between the Committee's First and Second Reports was the subject of a letter from Warwick Elley, Professor of Education at Canterbury University to the Minister of Education. Elley warned Marshall of the contradictions between internal and criterion-based assessment:

The main problem I see with the current proposal... is that it is attempting to move in two contrary directions at the same time. The movement towards internal assessment is a decentralizing movement. Each of 500 F.6 English and Science teachers will soon be evolving different courses and setting different tests and assignments, which is fine. But any move towards describing accurately what students know and can do requires a careful standardization of tasks and conditions which is easiest to bring about under a uniform examination and hardest under school-based systems... ${ }^{43}$

In a letter on the same theme to Jim Ross, the chair of the CICAQ and Assistant Director General of Education, Warwick Elley outlined the difficulties which would confront History and other content-based subjects in the standards-based assessment environment:

Whatever else the Liberal rhetoric has achieved, it is clear that it has raised an unrealistic expectation about what is possible in the matter of establishing standards of achievement, independent of any norm referencing... Subjects like English,

\footnotetext{
${ }^{40}$ Department of Education, First Report of CICAQ, 14.

${ }^{41}$ Department of Education, Learning and Achieving.

${ }^{42}$ Department of Education, Learning and Achieving.

${ }^{43}$ W. Elley to R. Marshall, 13 November 1986, R7 246 569, Archives New Zealand. (The underlining is in the original.)
} 
Science, History, Geography and Economics are multi-dimensional in their objectives, they have no homogenous knowledge domain that can be neatly carved up and they defy any accurate attempt to describe achievement in concise summary terms. ${ }^{44}$

\section{Tomorrow's Schools}

In relation to Sixth Form Certificate, Elley's fears were never realised. The Committee of Inquiry's Second Report and the Curriculum Review were both side-lined by a new round of political developments. In its second term, the Fourth Labour Government turned its reforming zeal to education administration. After the 1987 election, in a Cabinet reshuffle, Russell Marshall and Prime Minister David Lange swapped portfolios, with Lange becoming the new Education Minister and Marshall the Minister of Foreign Affairs. Subsequently, the political focus in education moved away from curriculum and assessment and onto administrative reform. While Roberts views these reforms as a neoliberal individualist philosophy being thrust onto education, ${ }^{45}$ Openshaw has stressed the continuity of the educational reforms of the late 1980s. He argues that the reforms were the culmination of a long period of educational disruption in which a heavily centralised educational bureaucracy was widely seen as a barrier to community involvement in schools and to the educational achievement of disadvantaged groups of students. ${ }^{46}$

Lange commissioned businessman, Brian Picot to chair a committee to comprehensively review the efficiency of educational administration in New Zealand. The Picot Report, Administering for Excellence, released in April 1988 concluded that the education system was "a creaky, cumbersome affair...

It is not the result of an overall plan or design, but has taken on its present shape in increments and accretion. Such a haphazard collection of administrative arrangements is not suited to the rapidly changing late twentieth century." ${ }^{\prime 4}$

\footnotetext{
${ }^{44}$ W. Elley to J. Ross, 10 March 1987, R7 246 574, Archives New Zealand.

${ }^{45}$ Roberts, "The Politics of Curriculum Reform," 29-46.

${ }^{46}$ Openshaw, Reforming New Zealand Secondary Education.

${ }^{47}$ Taskforce to Review Education Administration, Administrating for Excellence, 22.
} 
Picot's Committee recommended a 'blank page' approach to rebuilding the nation's education bureaucracy. The key principle governing the new structure was a belief that the best educational decisions were made closest to those who they affected the most; in the case of secondary education - in the school community. The running of schools was therefore to become a partnership between educational professionals and the community they served. School Charters were promoted as the 'Iynchpin' between the community, the school and the Government. ${ }^{48}$ The Department of Education including the Curriculum Development Division was to be disbanded and replaced by a much slimmer Ministry in which 'Policy' and 'Implementation' wings were to be separated. Further, it was recommended that the Inspectorate be replaced by an independent Education Review Office (ERO). ${ }^{49}$ An autonomous Qualifications Authority (NZQA) was also established to pick up the work of the Department's Examination Division. ${ }^{50}$ In August 1988, the Government released its response to the Picot Report - Tomorrow's Schools. This accepted the Picot Committee's recommendations without significant alteration and set in train a remarkably short timeline for implementation. The final day of the Department of Education was to be $30^{\text {th }}$ September, $1989 . .^{51}$

Although the ultimate aim of the reforms was to improve the quality of teaching and learning, the final report made only passing reference to curriculum and assessment. ${ }^{52}$ None of the teachers in this study recall the advent of Tomorrow's Schools having a significant immediate impact on their classroom teaching. There was concern however among History teachers at the time about the demise of the Department's Curriculum Development Division. O'Neill, Clark and Openshaw have suggested that the end of the consensus-based curriculum development process was a direct consequence of the view of Treasury officials that the curriculum had been captured by teachers for their own benefit. ${ }^{53}$ In the process a substantial body of curriculum expertise was lost. The Principal of

\footnotetext{
${ }^{48}$ Openshaw, Reforming New Zealand Secondary Education.

${ }^{49}$ Taskforce to Review Education Administration, Administrating for Excellence. The proposed title for ERO in the Report is the 'Review and Audit Agency.'

${ }^{50}$ The development of a separate agency to oversee assessment and qualifications in the secondary and tertiary sector was signalled through the 1988 Hawke Report. See: Hawke, Report on Post Compulsory Education.

${ }^{51}$ Taskforce to Review Education Administration, Administrating for Excellence.

52 Openshaw, Reforming New Zealand Secondary Education.

${ }^{53}$ O'Neill, Clark and Openshaw, "Mapping the Field," 25-46.
} 
Hamilton's Fraser High School, N.D. Ginever noted that the Picot Report had replaced cooperation with competitiveness and expressed the concerns of many when he asked "will we retain the opportunity to take part in courses on our subject area, both [sic.] local, regional, national?" ${ }^{54}$ Writing in 1989, History teacher, Ron Braithwaite (also from Fraser High School) identified the difficulties which the history community "would have to face up to" without a Department Curriculum Officer "in curriculum support, in-service training, and marketing the subject." 55

The relationship between teachers and various education officials changed as a result of Tomorrow's Schools. History teacher and PPTA activist, Bruce Taylor identifies the decision made in the 1990s that teachers would negotiate directly with the Ministry of Education over their pay and conditions (rather than with the State Services Commission) as a key factor in the breakdown of relations between teachers and the Ministry of Education. An additional feature of the new bureaucracy was an absence of education officials with subject specific knowledge. This also appears to have stemmed from the public management fear of 'provider capture. ${ }^{56}$ Comparing the era of Department with the era of the Ministry, Hamilton Girls' High School History teacher, Carol Jarman, suggested that a closer working relationship was possible in the days of the Department when the education officials had a background and understanding of the disciplinary thinking involved in a subject. ${ }^{57}$ Paul $\mathrm{O}^{\prime}$ Connor recalls a similar problem in his dealings with NZQA in his capacity as a History examiner:

They would [appoint] a NAF [National Assessment Facilitator] and you would just get this person on board, and explain this is how we do things in History, and then you would get someone else and you would have to train them all over again. So in the time that I was involved with setting exams, there were probably four or five that I had to consistently retrain... and I got sick and tired of having to do this. I thought it was a flawed policy. ${ }^{58}$

\footnotetext{
${ }^{54}$ Ginever, "A Historian's Peek."

55 Braithwaite, "Tomorrow's Schools and History."

${ }^{56}$ See: Taskforce to Review Education Administration, Administrating for Excellence, 23-25.

${ }^{57}$ C. Jarman, personal interview, May 26, 2011.

${ }^{58}$ P. O'Connor, personal interview, June 28, 2011.
} 


\section{Sixth Form Certificate Courses in Schools}

The Sixth Form Certificate was caught in-between these political developments. Little has been written about the experiences of teachers and schools with the qualification. In Chapter Five we will see that many History teachers utilised the flexibility of a school-based assessment programme which Sixth Form Certificate offered. Without the restrictions of an externally set examination, teachers found that they were able to follow interesting tangents, reduce or extend topics to enhance student interest and help students to develop in-depth disciplinary thinking. This view was shared by Charmaine Poutney, headmistress of Auckland Girls' Grammar School, who wrote to the new Minister of Education, David Lange about the impact of Sixth Form Certificate in her school in 1987:

The emphasis on school-based assessment of a wide range of skills and knowledge is having a dramatic effect on improving the standards of teaching and learning. Sixth Form students are now working throughout the year to develop research skills, oral and practical skills, as well as traditional memory and examination skills... however, because the distribution of grades is based solely on their performance in external examinations a year earlier, there is no way in which we can recognise this improvement in the grades which are finally allocated..$^{59}$

The grade allocation system plagued the Sixth Form Certificate qualification from its inception. Inglewood High School's principal, Bob Clague, used his 1987 prize-giving address to describe the grading system as "grossly unfair and socially destructive." ${ }^{60}$ Five years later, Tony Steel, the National Party Member of Parliament for Hamilton East and former Headmaster of Hamilton Boys' High School agreed, saying that it was "an absolute nonsense" that a previous year's results determined the grades available for distribution. He suggested that "Sixth Form Certificate need[ed] to be a 'stand alone' certificate, not one linked to School Certificate." ${ }^{61}$ Like these principals, most of the teachers who participated in this study disliked the system. They recalled the "horse trading" which took place

\footnotetext{
${ }^{59}$ C. Poutney to D. Lange, 1 December, 1987, R7 246 574, Archives New Zealand.

60 "School Head Slams System," Taranaki Herald, November 11, 1987.

61 “Link Between School Results Criticised," The Dominion, April 28, 1992.
} 
between subjects at the end of the year as "horrific", as Heads of Departments competed with each other in the fight for good grades for students in their subject areas. ${ }^{62}$

One problem which schools faced was the distribution of grades to Year 12 subjects (such as Drama) which did not have an equivalent Year 11 course. In the draft handbook which was issued to schools in 1986 (and never updated or made official), it was suggested that schools use a 'General Ability Indicator' to allocate grades to different subjects. This involved the school calculating the average School Certificate mark for each student and then allocating a requisite Sixth Form Certificate grade to each of the subjects that the student was studying. While this method made it possible for new subjects to be introduced into the curriculum at Year 12 and assessed alongside established subjects, it was underpinned by a flawed assumption that students had a similar proficiency across all their subjects. The 'General Ability Indicator' particularly affected subjects such as Art and Te Reo Māori, which assessed skills and knowledge distinct from other curriculum areas. One notable case became the subject of a Human Rights Commission complaint in 1997 and also gained the attention of Parliament's Māori Affairs Select Committee. The case involved a student of Te Reo Māori who gained a very high mark in School Certificate but despite being ranked the top Te Reo Māori student in the school in Year 12 gained only a mediocre Sixth Form Certificate grade. The case prompted NZQA to suggest schools be more flexible in their grade allocations. However, at both the Human Rights Commission and Parliamentary inquiries, officials explained that they were reluctant to overhaul the grading system, given the proposed abolition of Sixth Form Certificate and its replacement with a national certificate. ${ }^{63}$

The system threw up some further anomalies. In Whanganui, students from Sacred Heart and St Augustine's Colleges combined for their Year 12 Chemistry class. At the end of the 1986 school year, a student from one school who gained a raw mark of 73 was awarded a grade 'three', while a student from the other school with a mark of just 65 was awarded the higher grade of 'two'. Answering a Parliamentary Question on behalf of the Minister of

\footnotetext{
${ }^{62}$ For example, D. King, personal interview, April 12, 2011.

${ }^{63}$ Māori Affairs Parliamentary Select Committee, "Inquiry into Grade Allocation."
} 
Education, Labour MP Michael Bassett explained that the principals of the two schools made independent judgements taken from the pool of grades allocated to each school. ${ }^{64}$

The system for Year 12 grade allocation was complicated further by the removal of scaling from the Year 11 examinations. The aim of scaling School Certificate was to ensure consistency between subjects and between year groups, but for a long time it had been the focus of public disapproval. The 1990 National Party election manifesto promised to remove scaling from School Certificate. While this was a popular move when it was implemented just prior to the 1993 election, it simply transferred the problem onto Year 12, where grades were still allocated to schools based on scaled marks. ${ }^{65}$

Another feature of Sixth Form Certificate, especially in the early years, was excessive assessment. The tendency of teachers to assess every possible aspect of the curriculum was noted by the Department's Sixth Form Certificate Liaison Committee as early as March, 1986 - the first year of the Certificate's implementation. ${ }^{66}$ History teacher, Noeline Hannan's memories of those early years of internal assessment at Hutt Valley High School are typical of many teachers:

It wasn't so much fun teaching [Sixth Form Certificate courses] in the first year or two because [there] was just too much [assessment] and eventually we thought that we don't need to do that as often to get a valid result... But initially everyone was feeling their way with the new qualification, so... what we now call 'over-assessing' was just making sure that you didn't devalue the qualification. ${ }^{67}$

Throughout 1986, the Minister's in-tray was filled with complaints from parents and students about the excessive amount of assessment at Year 12 level. One student felt let down by the promises that had been made to her that internal assessment would be less stressful than external examinations:

\footnotetext{
64 "Wanganui Grading Debacle Revealed in Parliament," Wanganui Chronicle, May 1, 1987.

65 "Sixth Form Certificate Grades Allocation," March 22, 1996, CQ96/19S, March 22, 1996, NZQA Archives.

${ }^{66}$ Minutes from Sixth Form Certificate Liaison Committee, March 24, 1986, R20 474 774, Archives New Zealand.

${ }^{67}$ N. Hannan, personal interview, April 8, 2011.
} 
We were told how it made the year more relaxing and enjoyable... we are constantly having tests in all our subjects worth $5 \%$ or $10 \%$ of our year's total... my social life is non-existent... I have a minimum of one major test or assignment due each week... I hope that before you start screwing up the fifth and seventh form years, you give a thought for the students doing these courses - many who will be voting in the next election. ${ }^{68}$

Other student correspondents displayed even stronger political emotions. One from Auckland Grammar School, where the internally assessed programme appears to have been largely made up of a series of end-of-term examinations, directed his frustration at the Minister:

Here I am swotting for a set of examinations which will decide my grades for the supposedly internally assessed sixth form certificate. It is now far more difficult for a pupil to gain a standard tertiary bursary without wasting a year of his life in the seventh form, than in previous years when one need only pass the university entrance exam. You have let your otherwise good government down through your abolition of U.E. You are wasting my time. I hope you die soon. Please tell me what you are trying to achieve. I hate you. ${ }^{69}$

After some follow-up correspondence between Department officials and the Auckland Grammar School Headmaster, John Graham, Russell Marshall received an apology (of sorts) for the earlier letter:

You are obviously a very busy man, far busier than Mr Wellington ever was when he was in your office... in retrospect I am able to see that my anger probably had its beginnings in the violence inherent within the present education system with its so

\footnotetext{
68 "Sixth Form Certificate Student" to R. Marshall, Minister of Education - July 3, 1986, R7 246 558, Archives New Zealand. (As this is a restricted file, I have chosen not to name the student.)

69 "Auckland Grammar School Sixth Form Certificate Student" to R. Marshall, October 5, 1986, R7 246 569, Archives New Zealand. (As this is a restricted file, I have chosen not to name the student.)
} 
called 'good old traditional values' of corporal punishment. These are the exact 'values' which your government is trying to abolish and I wish you the best of luck in doing so. Perhaps in the near future, there will be fewer abusive teenagers like me... Good health and best wishes for next year's elections. If I was old enough, I would vote for you[! $]^{70}$

\section{Opposition to Internal Assessment}

Auckland Grammar was one of several schools vehemently opposed to the introduction of internal assessment, through Sixth Form Certificate. One response, beginning in 1986, was establishing an independent 'External Examination' (also called 'The Combined Schools Examination') for Year 12 subjects. The advent of these private examinations concerned the Sixth Form Certificate Liaison Committee at the Department of Education, especially when it was revealed that Auckland Grammar School was planning to use the results to determine student eligibility for progression to Year $13 .^{71}$ Although, in most cases, students sat these examinations in addition to their Sixth Form Certificate programme, their arrival marks the beginning of Auckland-led initiatives to find alternatives to the nationally mandated qualifications. Proponents of these examinations have consistently argued that internal assessment constitutes a 'dumbing down' of educational standards and that it lacks the rigour and competition which is required to bring the best out of students and their teachers. In 1994, the Principal of Avondale College, Phil Raffills suggested that internal assessment made Year 12 the least satisfactory school year for both teachers and students:

I don't believe that the Sixth Form year at any school in New Zealand is a successful year from the students' point of view and from the teachers' point of view. And that thought comes out over and over again when you're talking to kids and teachers, and the Sixth Form year is the year at schools where the kids are totally internally assessed. The kids don't like it; it puts stress on them. The teachers don't like it because there's no end point; there's no focus; there's no goal. ${ }^{72}$

\footnotetext{
70 "Auckland Grammar School Sixth Form Certificate Student" to R. Marshall, October 23, 1986, R7 246569 , Archives New Zealand. (As this is a restricted file, I have chosen not to name the student.)

${ }^{71}$ Minutes from Sixth Form Certificate Liaison Committee, July 17, 1986, R20 474 774, Archives New Zealand.

72 1ZB Radio Interview Transcript, Wednesday November 30, 1994.
} 


\section{Local Courses}

While a minority of schools chose to look outside of the Sixth Form Certificate system to meet the perceived needs of their school communities, others found solutions within it. One feature was the opportunity to step away from traditional subject disciplines and develop 'local courses'. This option had been available before the abolition of the University Entrance examination, but it became more attractive after 1985 because all courses now had equal status. As a result, local courses became very common throughout the country, with Auckland's Rutherford High School teaching twelve separate locally designed courses in $1986 .^{73}$ Schools were required to submit a course description and assessment statement for each local course for approval to the Department of Education (or NZQA from 1990). The History teachers in this study were involved with the teaching of local courses in Pacific Studies, International Relations, Sociology, Social History, Recreational Photography, Legal Studies, New Zealand Studies, and Government and Law.

\section{Unit Standards}

From the mid-1990s, the Year 12 curriculum became the testing ground for the Government's assessment initiative - unit standards. The unit standards approach was to break the learning of each subject up into a series of separate components to be internally assessed. The National Party had first proposed a modular certificate in their dramatically entitled 1987 election manifesto, A Nation at Risk. ${ }^{74}$ Although the National Party was defeated in 1987, the policy was still part of their plan for education when they were elected to office in 1990. The change of Government and the appointment of Lockwood Smith as the new Minister of Education coincided with the establishing of NZQA. Under the direction of Smith, the Authority began to develop the National Qualifications Framework (NQF). A 1993 brochure distributed to students through schools explained that the Framework would "help to create a 'seamless' education system that brings together secondary education, industry training and tertiary education beneath one umbrella." 75

\footnotetext{
${ }^{73}$ G. Cowley to W. Renwick, October 14, 1986, R7 246 574, Archives New Zealand.

${ }^{74}$ Openshaw, Reforming New Zealand Secondary Education.

75 "The National Qualifications Framework," 1993, NZQA Archives.
} 
In 1995, once the plans for the Framework were developed, Avondale College Principal, Phil Raffills suggested that internal assessment would replace "the joy of teaching [with] a resentment of assessment...

The philosophy is that external examinations or national standards produce tall poppies. And New Zealand is great for chopping down tall poppies. What NZQA want is to dumb down the system so that no kid stands head and shoulders above any other. In other words we're heading for the middle ground of mediocrity once again in New Zealand and that's what I object to."76

Despite vocal opposition, work began on translating the curriculum of conventional school subjects into unit standards. In most cases about 6-8 unit standards would be used to assess an entire course. Each unit standard was made up of one, two or three 'elements', with candidates required to show proficiency in each element's 'performance criteria' to be awarded the unit standard. Controversially, the unit standards had no grades - instead they functioned on a pass/fail (or 'achieved' and 'not achieved') basis. Unless a candidate showed proficiency in each performance criteria then she or he failed the unit standard.

When the trials began in 1995, they were accompanied by extensive professional development for the teachers involved. Participants were provided with a three-day subject-based workshop and then one-day workshops during each term of the year-long trial. NZQA appointed a facilitator for each subject, who toured the country for the year, hosting the workshops. The facilitator also collected assessment materials which had been generated by the trial schools and distributed these on disk and CD-rom to all of the schools involved in the trial. ${ }^{77}$ In many ways, this approach modelled the former Department's curriculum development model.

The development of the unit standards and the National Qualifications Framework became caught up in industrial action in 1996, with PPTA members placing a moratorium on its implementation, citing workload concerns in the middle of negotiations over their collective

\footnotetext{
${ }^{76}$ Radio Liberty 'New Freeland’ Interview Transcript, July 10, 1995.

${ }^{77}$ P. O'Connor, personal interview, June 28, 2011.
} 
contract. $^{78}$ As a result, NZQA contractor, Paul O'Connor found himself in the interesting situation of having one of his workshops boycotted not only by his own History Department from Burnside High School but also by his wife, who was a PPTA member and History teacher at another Christchurch school! ${ }^{79}$ The use of a moratorium on the development of the unit standards as an industrial weapon was indicative of a significant change within the teacher union. Since the publication of Education in Change in $1969,{ }^{80}$ the PPTA had led the campaign for increased levels of internal assessment for the benefit of students, but by the mid-1990s, concerns over teacher workload took priority.

In providing clearly defined outcomes for education, the unit standards appeared to fulfil a neoliberal agenda for education as serving the economy. ${ }^{81}$ As Geoff Chapple pointed out in the New Zealand Listener, once the unit standards were put in place, it would be easy to adjust them and register new unit standards to "dovetail education with the country's [economic] requirements for schools." ${ }^{82}$ As they were internally assessed, the unit standards also appeared to fulfil a long-standing liberal agenda of liberating teaching and learning from externally-set examinations designed to rank and fail students. Despite this apparent reconciliation of interests, vocal opposition to the proposed system's lack of grading and the anticipated impact of internal assessment on teacher workload stalled the unit standards in the trial phase. The National Certificate of Educational Achievement (NCEA), which emerged from the rubble of the unit standards, attempted to develop a compromise between these competing concerns. Sixth Form Certificate once again remained in place as a new series of standards were written and trialled.

\section{Social Studies and the New Zealand Curriculum Framework}

While the New Zealand Qualifications Authority was working on the development of the Qualifications Framework, officials of the streamlined Ministry of Education were working on Lockwood Smith's other project - the redevelopment of the New Zealand Curriculum Framework (NZCF). The NZCF specified seven learning areas which were seen as being

\footnotetext{
78 “Cabinet to Discuss Teachers' Concerns," Wanganui Chronicle, April 1, 1996.

${ }^{79}$ P. O'Connor, personal interview, June 28, 2011.

${ }^{80}$ NZPPTA, Education in Change.

${ }^{81}$ O'Neill, Clark and Openshaw, "Mapping the Field," 25-46.

${ }^{82}$ Chapple, "Elite Schools Waylay a Revolution," New Zealand Listener, July 23, 1996, 7.
} 
"essential for a broad and balanced education." ${ }^{83}$ These were not subjects, but "broad, recognisable categories of knowledge and understandings." ${ }^{84}$ The seven areas were Language and Languages, Mathematics, Science, Technology, Social Studies, The Arts, and Health and Physical Well-being.

The release of the Framework was followed by the writing of new curriculum statements in each of the learning areas. The new statements differed significantly from the general syllabus statements from the era of the Department. They were outcomes-based, specifying the skills and understandings which students were expected to have attained at each curriculum level. However, Social Studies in the New Zealand Curriculum ${ }^{85}$ differed from other learning areas because it failed to provide a clear taxonomy for development. The higher curriculum levels seemed to point teachers to different topics and settings rather than more sophisticated understanding or a more advanced set of skills. This illustrated the difficulties which curriculum designers had in imposing an outcomes-based framework onto a learning area which did not have a strong discipline base.

Social Studies had a long history in New Zealand schools from Years 1-10, but the new curriculum statement included achievement objectives for Social Studies right through to curriculum level eight, which was targeted at Year 13 students. This left the traditional senior social science disciplines; History, Geography and Economics outside the New Zealand Curriculum Framework, with their syllabus statements and examination prescriptions from the 1980s continuing to direct teaching and learning. In their 2004 Waikato case-study, Hunter and Farthing are critical of History teachers for not viewing their History programmes in relation to the concepts and processes of the 1997 Social Studies curriculum. ${ }^{86}$ They appear to misrepresent the nature of the senior secondary school where adherence to disciplinary approach, examination prescriptions and assessment dominate curriculum decisions. Without exception the History teachers in this study also saw their work in the senior school as being divorced from that in the junior school. While Year 9 and

\footnotetext{
${ }^{83}$ Ministry of Education, NZCF, 8.

${ }^{84}$ Ministry of Education, NZCF, 8.

${ }^{85}$ Ministry of Education, Social Studies in the New Zealand Curriculum.

${ }^{86}$ Hunter and Farthing, Talking History.
} 
10 Social Studies courses were adjusted to reflect the 1997 document, Year 11 to 13 History courses continued unimpeded.

\section{The National Certificate of Educational Achievement}

The manner in which History and other optional senior subjects sat outside the 1990s curriculum reforms underlined the importance of reform through assessment. Earlier we saw how the unit standards initiative met vocal opposition due its lack of both a differentiated grading scale and external assessment. The National Party Minister of Education between 1996 and 1999, Wyatt Creech, was less ideologically driven than his predecessor, Lockwood Smith, and prepared to make significant compromises within the proposed assessment system in order to build widespread support for it.

This new spirit was reflected within the changed leadership of NZQA. In 1996, Acting Chief Executive Officer, Murray Leach indicated that examinations would remain. In an interview with the Sunday Star Times, in December 1996, he explained that the Authority was "investigating proposals to bring external exams and the framework together into one integrated system to get the most out of both external and internal assessment." ${ }^{87}$ The arrival of a new CEO, Douglas Blackmur provided the Authority with the opportunity to address the other major criticism of the unit standards. In profiling the new qualifications head on his arrival from Australia, the New Zealand Herald explained that Dr Blackmur "disagreed fundamentally with the idea of a yes/no system and advocates an excellence scale, something he says can be adopted within a unit-standards-based education system." ${ }^{88}$

The Government announced its intentions for the new internally and externally assessed NCEA in November 1998. It was to have four levels (including Level Four for Scholarship students), with School Certificate and Bursary Examinations remaining for Years 11 and 13 to contribute to the Level One and Level Three Certificates respectively. Sixth Form Certificate was to be abolished in 2002, with 'Common Assessment Tasks' introduced as a form of external assessment, through which a centrally written assessment would be

\footnotetext{
87 "Externals are Here to Stay," Sunday Star Times, December 15, 1996.

88 "Quest for Excellence," New Zealand Herald, March 3, 1997.
} 
provided for school administration and marking. While the pass/fail unit standards were to be retained for non-conventional subjects, 'achievement standards' would be written for conventional subjects with 'achieved', 'merit' and 'excellence' criteria written into them. ${ }^{89}$

Despite the significant changes made to the unit standards system, several vocal critics were unimpressed. The critique of satirical columnist Joe Bennett, a former English Teacher in Christchurch's independent Christ's College focused on the philosophical contradictions inherent in the new system:

The NCEA is what you get from mating the traditional system of examinations with the collapsed idea of unit standards. Inevitably the child is illegitimate... The NCEA is built on the belief that all subjects from boiler-making to philosophy can and should be assessed by the same system; and that when we teach children we are simply preparing them for jobs; and that failure is bad for children; and that a subject like English can be divided into chunks which can be learned, tested, and ticked off the list. All of these beliefs are fallacies. ${ }^{90}$

Several schools, especially in Auckland, which had been consistent in their opposition to internal assessment, announced that they would be walking away from the new qualification and entering their most able students in alternative examinations. ${ }^{91}$ Most notable among these was the Cambridge International Examination (CIE) system. By 2002, an office of this private company had been established in Auckland to promote and coordinate their examinations throughout New Zealand.

The change of Government at the end of 1999 had little impact on the NCEA. The new Labour Party Minister of Education, Trevor Mallard, delayed implementation for a further year but the structure of the NCEA largely remained intact. So in 2003 , the Sixth Form Certificate was finally abolished. By this stage, the language of the Government's proposal had changed with the School Certificate examination replaced by the new NCEA Level One

\footnotetext{
89 J. Gerritson, "New Assessment System Announced," NZ Education Review, November 4, 1998, 4, NZQA Archives.

90 J. Bennett, “Another Edifice Built on Fallacies," The Press, November 24, 1999.

91 "Schools Discuss Breakaway Exam System," The New Zealand Herald, December 9, 1999.
} 
Examination and the 'Bursary' examination by the 'NCEA Level Three Examination.' The concept of the 'Common Assessment Tasks' for Year 12 had also been scrapped and replaced by the NCEA Level Two Examination. In Chapter Seven, we will see how the introduction of a standards-based externally set examination to assess a curriculum which had been designed around a broad syllabus with the intention of it being internally assessed, created a new set of problems for History teaching and learning.

\section{Conclusion}

This chapter has sketched the wider educational backdrop for this case study of Year 12 History between 1986 and 2005. It shows that for all subjects, the Year 12 curriculum and its accompanying assessment and qualifications were caught in-between the different philosophies and policies promoted by different Ministers. It has also shown how Year 12 programmes were caught in-between the different approaches of the educational agencies before and after the 1989 Tomorrow's Schools reforms. As Year 12 sat in-between the high stakes examination courses of Years 11 and 13, it became the testing ground for a range of different ideas in assessment, but the changing political and educational landscape prevented permanent change, leaving it in limbo. The extent of the compromise which was reached by 2003 through the NCEA was, in the case of History, to have a further detrimental impact. 


\section{Chapter Four}

\section{Developing the Year 12 History Curriculum}

Women's history, the Māori renaissance, an awareness of indigenous history, New Zealand's standing in the world and particularly in the Pacific and Asia... all fought for a place in the new syllabus, and the Sixth Form Certificate prescription became the dumping ground for all these ideas. ${ }^{1}$

David Wood

\section{Introduction}

This chapter focuses on the development of the curriculum documentation for Year 12 History in the mid-1980s. It argues that the final documentation was a result of compromises within the National History Curriculum Committee and between the Committee and the wider History teaching community. The new Syllabus for Years 11 to 13 emphasised History skills and introduced new approaches to teaching. The Sixth Form Certificate History Prescription which emerged introduced new topics focusing on Māori, Pacific and women's history but also retained the largely European focussed topics already being taught in schools. ${ }^{2}$ This chapter suggests that the introduction of the Tomorrow's Schools reforms, during the implementation phase of the curriculum development, led to inadequate resourcing of the new topics. This factor, combined with high levels of teacher autonomy provided by internal assessment and the wide range of topics made available, threatened to undermine the aims of the curriculum.

\section{Context of Reform - University Entrance History}

On the $11^{\text {th }}$ and $12^{\text {th }}$ October, 1982, a group of History academics and Department of Education officials met in the Education Department buildings in Wellington. The meeting came about at the request of the New Zealand Historical Association and resolved to establish a History Curriculum Committee. ${ }^{3}$ The new committee was "to consider and amend the aims and objectives for history in forms 5-7; consider and rationalise the content

\footnotetext{
${ }^{1}$ D. Wood, personal interview, April 8, 2011 (amended transcript).

${ }^{2}$ For a summary of the topics available for teachers at different times see page 7.

${ }^{3}$ Bassett, "National History Curriculum Committee," 2.
} 
and review the amount to be studied at each level; ...suggest approaches for studying history, and especially to stress the skills involved in the discipline of history." ${ }^{4}$

The Terms of Reference, generated at this October meeting, reflect the concerns which many university academics had about the state of History education in New Zealand. Hargreaves has shown that school subjects are more than just groupings of intellectual thought, instead they "compete for power, prestige, recognition and reward within the secondary or high school system." ${ }^{5}$ In the early 1980s, History at the secondary level was at low ebb. Despite the general trend of increasing retention of students through to the senior years of New Zealand secondary schools ${ }^{6}$, History numbers were falling. In 1980, the editor of the Historical News expressed concern at the "continued steady decline in History numbers in schools" noting that "Geography in [Year 11] enjoy[ed] almost double the numbers attracted to History." ${ }^{77}$ The situation was even more concerning for Year 12 History. While 40.6 per cent of all students had enrolled for University Entrance History in 1963, just 31.7 per cent of Year 12 students did so in $1980 .^{8}$ History was seen to be a "difficult subject, involving high factual content and excessive written work... for most pupils it seem[ed] irrelevant both personally and vocationally." ${ }^{\prime 9}$

The students who did select History as a Year 12 subject in the early 1980s studied a course which was based around four themes. ${ }^{10}$ Teachers chose from 13 illustrative case study topics, of which nine were from European settings and two were from Asia. There was one topic based on the history of the USA and another set in southern Africa. ${ }^{11}$ Despite the growing body of literature on New Zealand (and to a lesser degree Pasifika) history, there were no topics set in the South Pacific.

\footnotetext{
${ }^{4}$ History Syllabus Committee Forms 5-7 Terms of Reference, P. Lineham Papers.

${ }^{5}$ Hargreaves, Curriculum and Assessment Reform, 56.

${ }^{6}$ O'Neill, "Change and Constancy."

7 "Careers for History Students", New Zealand Historical Association News, 18.

${ }^{8}$ P. Capper, "University Entrance to Form Seven," R7 246 543, Archives New Zealand.

9"Careers for History Students," New Zealand Historical Association News, 18.

${ }^{10}$ The themes were: 'Nationalism in the $19^{\text {th }}$ and early $20^{\text {th }}$ centuries', 'Imperialism and the expansion of Europe in the late $19^{\text {th }}$ and early $20^{\text {th }}$ centuries', 'Theory and practice of government in the $19^{\text {th }}$ and early $20^{\text {th }}$ centuries' and 'International relations from 1814 to 1919 '.

${ }^{11}$ University Entrance Board, University Entrance History Examination Prescription 1985.
} 
The courses taught in most schools were highly Eurocentric. The programme taught at Burnside High School in Christchurch, a large co-educational school with a strong academic record was typical of most New Zealand schools. Year 12 students studied topics which focused on the European state system, Russia, Italy, Germany and the build up to the First World War. ${ }^{12}$ There was a strong emphasis on students having a 'good set of notes' from which they could learn factual content and recall it in their examinations and essays. ${ }^{13}$

As the examination was designed to screen candidates for university, it was academically demanding. Up to sixty per cent of the end-of-year three-hour examination was made up of essay style questions, which assessed student understanding of their selected themes as well as the topics. The remainder of the paper was based on recall questions and topic or theme-based source analysis questions. ${ }^{14}$ However, most Year 12 history students did not sit the examination. In 1985, more than 60 per cent (2974) of New Zealand's (4851) Year 12 History students were accredited. ${ }^{15}$

This hybrid of internal and external assessment presented both difficulties and opportunities for the teachers in this study. Paul Wulff, for example, was teaching at Dannevirke High School in the early 1980s. He recalls the struggle he experienced attempting to motivate students who were confident of gaining accreditation due to their ability or connections, while, at the same time attempting to keep the students who were unlikely to be accredited focused enough to pass the examination. ${ }^{16}$ For Carol Jarman at Hamilton Girls' High School, the accreditation process provided freedom:

Really, your only requirement was to provide a ranked-list for accreditation and ... people weren't that interested in how you found your ranked list. You could have done it just as easily on height... or some completely random reason. ${ }^{17}$

\footnotetext{
${ }^{12}$ P. O'Connor, personal interview, June 28, 2011.

${ }^{13}$ P. O'Connor, personal interview, June 28, 2011.

${ }^{14}$ University Entrance Board, University Entrance History Examination Prescription 1985.

${ }^{15}$ University Entrance Board, University Entrance History Examination Prescription 1985.

${ }^{16}$ P. Wulff, personal interview, June 29, 2011.

${ }^{17}$ C. Jarman, personal interview, May 26, 2011.
} 
As a beginning teacher, she quickly discovered that the students could be adequately prepared for the examination with an in-depth understanding of just one or two topics. This provided her with the autonomy to move beyond the restrictions of the examination prescription into areas of study which were of more interest to her and to her students and to use a variety of teaching strategies which enhanced student interest. ${ }^{18}$

Most teachers were satisfied with the status quo. In February 1983, prior to the first meeting of the National History Curriculum Committee, Department of Education officials surveyed New Zealand's History teachers to ascertain their perceptions of the various syllabus and prescriptions which were operating in schools. Although comments were made about the need for more social and economic history options and for studies outside of Europe, 83.5 per cent of those who responded reported that they were "generally satisfied" with the Year 12 course. In reply to a question about whether the aims and objectives needed closer definition, 63.7 per cent said "no". ${ }^{19}$

\section{The National History Curriculum Committee}

These positive views of the state of Year 12 History do not appear to have been shared by all of those on the National History Curriculum Committee. Sheehan has examined the operations of this committee and argued that the curriculum was captured by powerful groups of academics and teachers who shaped the curriculum to reinforce their personal and professional positions. He argues that the consensus approach of the Department of Education allowed dominant stakeholders to have a disproportionate influence. ${ }^{20}$ This was less apparent at Year 12 level than at Years 11 and 13, which were deemed to be the "high stakes' levels due to their prestigious School Certificate and University Bursary examinations. Consequently, many of the topics which were overlooked for the Year 11 and 13 courses eventually found their home in the Year 12 documentation.

As we saw in Chapter Three, by the 1980s a model of curriculum development had evolved in the Curriculum Development Division of the Department of Education, which emphasised

\footnotetext{
${ }^{18}$ C. Jarman, personal interview, May 26, 2011.

19 "Survey of Needs - Results of Survey", History Newsletter 5.

${ }^{20}$ Sheehan, "The Place of New Zealand," 671-91.
} 
and gave priority to wide participation over intensive research and development. ${ }^{21}$ This model appears to have helped bring about slow changes to classroom practice, but it may also have hindered the development of a clear philosophical vision at the centre of the curriculum. This was particularly the case for Year 12 History where the already established thematic approach allowed for the relatively easy addition of new illustrative case study topics without significant reworking of the existing syllabus.

The apparent inability of the committee to establish a new philosophical basis for the curriculum was noted in a History teachers' journal by The Correspondence School's Neil Marshall in November 1984. He argued that a "major failing of the NHCC is its obsession with the content of the syllabus. Defining the content should be the last stage of writing a syllabus. Before that a conceptual basis should be established."22 He was particularly critical of the initial questionnaire sent to teachers. "This questionnaire did not ask what sort of syllabus was wanted in the future. Instead it asked what teachers thought was wrong with the present syllabus. Thus the NHCC seems to have merely tinkered with the old syllabus instead of designing a new one."23

A call for radical change in the journal of a subject association is unusual and, in this case, it was tempered by an editor's note indicating that the "point of view expressed is a private one and is not necessarily the view of the WAHTA [Wellington Area History Teachers' Association] committee." ${ }^{24}$ Membership of subject communities can be accompanied by a shared set of beliefs and assumptions which reflect the status quo and make the implementation of substantial changes to curriculum difficult. ${ }^{25}$ The editor's note in this case appears to indicate that leadership of the subject association were conscious of not causing offence to the Department officials and others working on syllabus revision.

\footnotetext{
${ }^{21}$ McQueen, "Once Were Curriculum Developers."

22 Marshall, "The National History Curriculum Committee," Wellington Area History Teachers' Association Newsletter 3, November 1984, 3.

${ }^{23}$ Marshall, "The National History Curriculum Committee," 3. (The underlining was in the original).

${ }^{24}$ Editor's note to Marshall, "The National History Curriculum Committee," 3.

${ }^{25}$ Hargreaves, Curriculum and Assessment Reform.
} 


\section{New Emphases}

One significant development for the syllabus was establishing a rationale and a skills base for the curriculum. In the mid-1980s, an English educationalist Ann Low-Beer spent a year in Wellington. Through her involvement with the United Kingdom's Schools' Council History Project, she had come to the conclusion that History was an ideal discipline for students in the information age. Many of these ideas were reflected in the wording of the new syllabus. ${ }^{26}$ As a result, the History Forms 5 to 7 Syllabus for Schools opened with a section entitled 'The Place of History in Schools.' This explained that the "purpose of history in schools is not only to provide knowledge and understanding but to develop skills and attitudes." $^{27}$ The syllabus also identified 'Skills Objectives' for the syllabus. These were organised under the broad headings of 'Information Gathering', 'Information Processing' and 'Presentation'. ${ }^{28}$ The identification of some explicit History skills was a major development in the New Zealand History curriculum, but it appears to have been completely non-contentious. Both the participants on the committee and teachers were far more concerned with the historical content which was to be prescribed for each level of study.

Apple has described education as "a site of conflict about the kind of knowledge that is and should be taught, about whose knowledge is official, and about who has the right to decide what is taught [and] how it is organized." 29 Different participants brought with them predetermined ideas about content areas they wanted written into the prescriptions. Openshaw has demonstrated how Wellington's small-scale policy environment in the early 1980s enabled those on both the political Right and Left to find common ground to operate in. $^{30}$ In the History curriculum, 'conservatives' promoted the teaching of European history, while 'liberals' emphasised the contested nature of New Zealand history. However, both groups agreed, that secondary school History should reflect the style and nature of the

\footnotetext{
${ }^{26}$ D. Wood, personal interview, April 8, 2011.

${ }^{27}$ Ministry of Education, History Forms 5 to 7 Syllabus, 5.

${ }^{28}$ Ministry of Education, History Forms 5 to 7 Syllabus, 8-9.

${ }^{29}$ Apple, "Curriculum Planning," 25.

${ }^{30}$ Openshaw, Reforming New Zealand Secondary Education.
} 
disciplinary knowledge of the parent discipline. ${ }^{31}$ Within this zone of agreement, the curriculum was developed.

Wood remembers "women's history, the Māori renaissance, an awareness of indigenous history, New Zealand's standing in the world and particularly in the Pacific and Asia"32 as key areas that different members of the committee wished to promote. Wood himself was deeply influenced by the egalitarian vision of the Director General of Education. Bill Renwick was determined that affirmative action should be taken to address the wide educational gaps which existed between Māori and Pacific Island students on one hand and Pakeha students on the other. There was also a Department-wide emphasis on developing curriculum policy which would lead to improvements in the level of achievement which New Zealand girls gained relative to New Zealand boys. "It is no accident" recalled Wood "that such emphases are found in the History syllabus." ${ }^{33}$

\section{Impact of Internal Assessment on Curriculum Development}

The consequences of a key political development outside of the control of Wood or the committee smoothed the path of the introduction of topics in Māori, Pacific and Women's history into the curriculum. The introduction of the fully internally assessed Sixth Form Certificate as the sole national award for Year 12 students from 1986 freed the subject from the constraints of an external examination. This development unleashed a vast range of possibilities for the teaching of History.

The arrival of full internal assessment for the Year 12 course forced the committee to consider an important question: should the curriculum identify topics at all? In the past the topics had only been mandated through the examination prescription which was to be abolished. In his capacity as Chairman of the Hawke's Bay History Teachers' Association, Hastings Boys' High School teacher, Mark Cleary, lobbied committee chair, Colin Davis, about this issue:

\footnotetext{
${ }^{31}$ Sheehan, "The Place of New Zealand," 671-91.

32 D. Wood, personal interview, April 8, 2011 (amended transcript).

${ }^{33}$ D. Wood, personal interview, April 8, 2011 (amended transcript).
} 
The feeling was that the guidelines for the [Year 12] syllabus should consist of a list of themes that could be studied with a prescribed list of skills that must be developed. The removal of the UE exam allows enormous freedom for us to study themes and topics that suit our particular students. Failure to do so will see the rapid demise of secondary school history. ${ }^{34}$

This discussion mirrored a philosophical debate among the staff in the Department of Education's Curriculum Development Division. The head of the Social Studies wing, Rex Bloomfield, believed that the most important aspect of learning was the development of skills and appropriate attitudes and values. He believed that schools should have the freedom to choose the content which was most relevant to their local situation. However, David Wood was opposed to this 'downgrading' of the value of content ${ }^{35}$ and he appears to have had little trouble convincing the committee to press on with the development of a content-specific internally assessed Sixth Form Certificate Prescription.

Even with mandated topics, the demise of the external examination opened up the content of the Year 12 curriculum considerably. A national examination required a common body of historical content with agreed parameters but through internal assessment teachers would be able to control both the curriculum and the assessment. This freed up the committee to introduce far more topics than had previously been considered appropriate. The gazetted Sixth Form Certificate History Prescription had 25 potential topics - twelve more than the University Entrance Examination Prescription which it replaced. The plethora of new topics caused Massey University historian and committee member, Peter Lineham, to comment that the committee had often "seemed to adopt proposals simply at the whim of any one participant." ${ }^{36}$

The curriculum designers could be much less specific about the prescribed topic dates and allow teachers to emphasise aspects within the topics which suited them. For example, a

\footnotetext{
${ }^{34} \mathrm{M}$. Cleary to C. Davis, May 27, 1985, P. Lineham papers.

${ }^{35}$ D. Wood, personal interview, April 8, 2011.

${ }^{36}$ P. Lineham, "National History Curriculum Committee Report," 8-9.
} 
topic entitled 'Case Studies in Industrial Cities', was introduced. ${ }^{37}$ The supporting teacher notes provided examples of industrial cities which could be studied but encouraged teachers to choose their own. ${ }^{38}$ 'Small Power Conflict since $1945^{\prime}$ was a further new topic which invited teachers to design their own programme of learning within the broad parameters provided by the syllabus. ${ }^{39}$ A draft outline from Auckland University's Professor of History Keith Sinclair on the new topic 'The Growth of New Zealand Identity 1890-1985' also entered into the spirit of internal assessment. Sinclair wrote that the proposed "topic enables teachers to introduce discussions in various contexts, according to their special interests, or those of classes: e.g. sporting or literary history: the views of Maoris [sic], women, immigrant groups." 40 The freedom for teachers provided by this new style of curriculum reflected a wider movement in education decision-making away from the centralised educational bureaucracy to schools and communities, which had its ultimate expression through the Tomorrow's Schools reforms. It also embraced international developments in History education. The United Kingdom's Schools' Council History Project emphasised that teachers should select topics and approaches which were relevant to their students. Chronological and teacher-dominated approaches were seen to be less effective than student-centred methodologies using historical skills to inform contemporary historical issues and debates. The teaching of fewer topics in greater depth was also promoted to develop disciplinary thinking. ${ }^{41}$

\section{Themes and Topics}

All of the new topics were still tied to four themes similarly to the University Entrance Prescription, with the topics intended to be illustrative of wider historical movements and trends. The themes were broadened to capture the new topics and altered to reflect contemporary historical concerns. ${ }^{42}$ The grouping of the topics under these new themes appears to have caused very little reaction from History teachers, who seemed to be more

\footnotetext{
${ }^{37}$ Department of Education, "Sixth Form Certificate History Course Statement."

${ }^{38}$ Department of Education, Form Six History.

39 Department of Education, "Sixth Form Certificate History Course Statement."

${ }^{40}$ Sinclair, "Draft Outline - The Growth of New Zealand National Identity," P. Lineham papers.

${ }^{41}$ Phillips, History Teaching.

42 The revised themes for Year 12 History were 'Industrial and Social Change', 'Nationalism, International Relations and the Search for Security', 'Government and Political Change' and 'Imperialism, Indigenous Peoples and the Emergence of New Nations'.
} 
concerned about the retention of their favourite topics than which themes they were organised under. However, for some university academics, whose discipline-based thinking emphasised the importance of historical context, the link between theme and topic caused consternation. Massey University's Basil Poff was asked to comment on the proposed topic, 'Gandhi and the Indian Struggle with the British Raj', which was initially placed under a draft theme entitled 'Imperialism and the Emergence of Modern Nationalism'. He described this task as being asked to "deal with this nest of wasps." He argued that...

Gandhi was in fact opposed to much that is most characteristic of nationalism and linking him to the thematic study... creates all sorts of problems. The likely consequence is that Gandhi will be trimmed down to fit the role of nationalist leader; all the 'excresences' [sic.] which in my view are fundamentally related will be dropped out of the picture or disposed of as crankiness. However tidy the result, it is not Gandhi." ${ }^{\prime 3}$

Massey University Pacific historian, Kerry Howe, had similar misgivings about a proposed Pacific history topic:

For at least thirty years historians of non-European peoples have been highlighting the fact that they have histories of their own... None of the proposed themes seem to take account of this. The proposed Pacific Islands topic seems to have been chosen to fit a theme... But if you want to introduce Pacific islands history... a rather different theme needs to be devised - one which will reflect whatever strengths the sub-discipline of Pacific Islands history has developed... ${ }^{44}$

In this case, the Committee appears to have taken some of Howe's views on board and sought the input of a Pacific Island historian, Malama Meleisea, into the proposed Samoan topic, as David Wood recalled:

\footnotetext{
${ }^{43}$ B. Poff to C. Davis, April $16^{\text {th }}, 1985$, P. Lineham papers.

${ }^{44} \mathrm{~K}$. Howe to C. Davis, April $2^{\text {nd }}, 1985$, P. Lineham papers.
} 
We chose the topic that was 'reverse colonialism.' Here is an island nation which is clearly important to New Zealand. We have a growing number of Samoans in this country... To meet the expected requirement of the New Zealand Curriculum, the topic needs to focus on New Zealand's role in Samoa. To meet the demand of the Pacific History Teachers' Association it needs to be written from a Samoan perspective. The upshot was a prescription and resource booklet written in Samoan... and translated into English. To the best of my knowledge it was the first of its kind in the history of curriculum development in New Zealand. ${ }^{45}$

The development of the Samoan case study from the perspective of Samoans, underlined the gap which existed in the curriculum for a topic which drew on Māori perspectives. In fact there was very little New Zealand history taught at all. Sheehan has commented that a unique feature of the New Zealand History curriculum is its inability to provide students with a 'grand narrative' of New Zealand history. He contends that this is a consequence of the committee being dominated by historians who viewed school History as a microcosm of university History programmes and their strong desire to emphasise the contested nature of New Zealand history. ${ }^{46}$ Although none of the previous thirteen University Entrance topics had focused on New Zealand content, the new prescription provided schools with the opportunity to select from five New Zealand topics. ${ }^{47}$

Wood shared the vision of the Department of Education's Director General, Bill Renwick, that educational decisions should be made in accordance with the Treaty of Waitangi principle of partnership between the Crown and Māori. ${ }^{48}$ After discussion with the Committee, Wood organised a hui in Gisborne in which Māori leaders and historians were to work with Department officials to select some Māori history topics for the Years 11 to 13 curriculum. Delegates at the Gisborne hui discussed the possibility of identifying some nationally recognised Māori figures such as Rongowhakata chief, Te Kooti Arikirangi, to be studied by Year 12 students across New Zealand. Te Kooti would have been a popular

\footnotetext{
${ }^{45}$ D. Wood, personal interview, April 8, 2011 (amended transcript).

${ }^{46}$ M. Sheehan, "The Place of New Zealand," 671-91.

47 These were: 'New Zealand and Economic Change and its Social Consequences 1879-1914', 'Women, Family and Work in New Zealand 1880-1960', 'From Colony to Nation: New Zealand Government 1840-1947,' 'The Growth of New Zealand Identity 1890-1985,' and 'Māori Leadership in the Nineteenth Century'.

${ }^{48}$ D. Wood, personal interview, April 8, 2011.
} 
choice in schools and in the Department. Between 1978 and 1981 in conjunction with Palmerston North Teachers' College, the Department of Education had funded The Te Kooti Project. This involved collecting written and oral material from a range of Maori sources relating to Te Kooti and making them available for schools. ${ }^{49}$ However, the Conference deemed this approach "a Pakeha way of doing it." ${ }^{50}$ The conference was almost entirely conducted in Te Reo Māori and involved notable historians including Judith Binney and Ngati Porou's Api Mahuika. The delegates decided that instead of mandating historical figures for students across the country, the decisions about who to focus on should be made by local Māori as David Wood explained:

The conference confirmed my perception that Māori were much more iwi, hapu, regional (viz they operated in tribes). They kept talking about their whakapapa. They didn't talk about a nation called 'Māori' even 'Aotearoa/New Zealand'; they talked mostly about their iwi. So, I concluded what we need to do is work intimately with the local community and to get them to authorise the process, even to select the local topics that their community schools are going to study. Such Iwi/whanau/hapu were even to be invited in sharing in matters of content and even assessment. It was a radical concept for the time and Bill Renwick was supportive. ${ }^{51}$

The new Prescription contained two Year 12 topics which specifically focused on the role of women in history: 'Participation of Women in the Emerging British Democratic System 18601930' and 'Women, Family and Work in New Zealand 1880-1960.' Women's history also featured prominently in the Year 11 and 13 courses. Sheehan has argued that powerful women from both the tertiary and secondary sector worked together and strategically within the committee to ensure a strong women's history presence in the syllabus. ${ }^{52}$

In February 1985, a working group on 'Women's Issues' met to discuss the revision of the syllabus. Their report to the wider committee focused on structural problems within the proposed syllabus, particularly in Year 12 where teachers were required to choose just four

\footnotetext{
${ }^{49}$ Openshaw, Reforming New Zealand Secondary Education.

${ }^{50}$ D. Wood, personal interview, April 8, 2011 (amended transcript).

${ }^{51}$ D. Wood, personal interview, April 8, 2011 (amended transcript).

${ }^{52}$ M. Sheehan, "Defending the High Ground."
} 
of the 25 topics, covering a minimum of two of the themes. They concluded that "the balance of the whole syllabus need[ed] to be re-examined as the current emphasis on political issues necessarily excludes the experience of much of society, especially the experiences of women." ${ }^{53}$ The sub-committee highlighted the conundrum of a curriculum which provides a high level of autonomy for teachers - how could the curriculum designers ensure that teachers made the 'right' decisions? The sub-committee viewed "with alarm the imbalanced perspective many young men and women will continue to obtain about the past if their teachers choose topics with no social history content - a likely possibility under this proposed structure." ${ }^{54}$ To counter this, the sub-committee produced a proposed statement about women's history which they wanted to be included in the preamble to the syllabus. A heavily diluted version of this statement was eventually included (alongside a statement about the importance of a Māori perspective) under the heading 'Programme Planning, ${ }^{55}$

The Sixth Form Certificate prescription also contained three new topics which were set in Asia: 'Japan's Decision to Industrialise and its consequences 1867-1930,' 'The Making of Malaysia' and Vietnam and the Conflict in Indochina 1945-1975. ${ }^{.56}$ In addition, topics on Indian and Chinese history were retained from the University Entrance Prescription. This preponderance of Asian topics reflects the research and teaching interests of Nicholas Tarling, the Acting Vice-Chancellor of Auckland University - an expert in Asian Studies. ${ }^{57}$ As well as being an influential member of the National History Curriculum Committee, Tarling was heavily involved in the Auckland History Teachers' Association, often summarising the discussions which were held in Auckland about the proposed curriculum and reporting these in both written and oral form to the committee. ${ }^{58}$ At a time when there was concern to foster New Zealand's economic relations in Asia, Tarling's standing and connections appear to have combined to create a strong Asian flavour in the Year 12 History documentation.

\footnotetext{
${ }^{53}$ Report of the Working Group on 'Women's Issues,' P. Lineham papers.

${ }^{54}$ Report of the Working Group on 'Women's Issues,' P. Lineham papers.

${ }^{55}$ Ministry of Education, History Forms 5 to 7 Syllabus.

${ }^{56}$ Department of Education, "Sixth Form Certificate History Course Statement."

${ }^{57}$ D. Wood, personal interview, April 8, 2011.

58 e.g. Tarling, "Feedback from the Auckland History Teachers' Association," September $26^{\text {th }}, 1984$, P. Lineham papers. This includes the comment "There was also some suggestion that a Southeast Asian topic, might be included here, perhaps on Malaysia/Singapore if not Indonesia."
} 
As well as providing scope for a raft of new topics, the arrival of internal assessment provided opportunities for students to undertake meaningful historical research as part of their course assessment through 'Special Studies.' The development of 'Special Studies' mirrored developments which arose from the United Kingdom's Schools' Council History Project. The project found that self-directed research tasks allowed students to develop interpretation and analysis skills within the context of a topic which was meaningful to them. These skills developed students' capacity to develop disciplinary thinking. ${ }^{59}$

Many teachers including Paul O'Connor responded very positively to the idea that students could undertake some 'hands-on-history' in order to develop discipline-based skills within their course of study:

I thought it was great... when I taught down in Timaru, I remember reading about some riots which occurred between some of the Irish citizens and the Protestant citizens... I thought then, wouldn't it be great if you could take the kids into the Timaru Herald offices and actually investigate that? But there was no prospect of doing that sort of thing at that particular time... This is what history is. It's not about regurgitating what historians think; this is about being an historian. ${ }^{60}$

\section{Opposition and Compromise}

Throughout the development process, many of the Year 12 proposals received criticism. This was particularly the case when an initial proposal was distributed to schools in 1984. Both the Manawatu History Society ${ }^{61}$ and a Wanganui history teachers meeting ${ }^{62}$ adopted resolutions in favour of the existing syllabus. A discussion of teachers held at Massey University became heated when the Year 12 scheme was again raised. Committee chair, Colin Davis reported that teachers were very dissatisfied with the proposals. ${ }^{63} \mathrm{~A}$ questionnaire on the proposed changes prompted one teacher to suggest that "we should

\footnotetext{
${ }^{59}$ Phillips, History Teaching.

${ }^{60}$ P. O'Connor, personal interview, June 28, 2011.

${ }^{61}$ Manawatu History Society Resolutions, May 30, 1984, P. Lineham papers.

${ }^{62}$ Report from Wanganui History Teachers Meeting (9 Teachers), 13 June 1984, P. Lineham papers.

${ }^{63}$ C. Davis, "Summary of Preliminary Discussion," August $10^{\text {th }} 1984$, P. Lineham papers.
} 
teach what students want and not what teachers and university people think they should learn." ${ }^{64}$

The debates concerning the Year 12 course were not peculiar to History or New Zealand. Apple has shown that internationally, curriculum development has always been the result of "tensions, struggles and compromises." 65 He suggests that "what counts as core knowledge has all too often been someone's core, not everyone's core." ${ }^{66}$ In this instance, the committee initially justified the proposed changes by contending that, while popular, the existing programme was "essentially a syllabus of the early 1960s [reflecting] the concerns and preoccupations of that time, many of which are now not seen as relevant." 67 The committee went on to note the changing composition of the Year 12 cohort and the increasing numbers of Year 12 students not intending to attend university, as reasons for change. ${ }^{68}$ Despite these valid justifications, the final list of prescribed topics submitted to the Minister of Education for approval retained nine of the thirteen University Entrance topics. $^{69}$ This compromise allowed teachers to choose to avoid substantive change to the content of their programmes. While the curriculum committee appears to have been willing to include topics which focused on women's and indigenous history, they refused to make any of these mandatory.

\section{Resourcing the Curriculum and Tomorrow's Schools}

Teacher concern about change centred on the provision of resources for the new topics. Richard Webb, who taught History at Queen's High School in Dunedin in the 1980s, remembers how tied teachers were to textbooks in the pre-internet age, given their limited photocopying budgets and their lack of suitable video material. ${ }^{70}$ Prompted by a paper presented by Richard Phillips, Chairman of the Auckland History Teachers' Association, expressing his concern that syllabus and prescription changes might be devised without consideration of the availability of suitable classroom resources, the committee discussed

\footnotetext{
${ }^{64}$ Teacher Survey Comments, undated, P. Lineham papers.

${ }^{65}$ Apple, "Curriculum Planning," 35.

${ }^{66}$ Apple, "Curriculum Planning," 35.

${ }^{67}$ Department of Eduation, History Newsletter 6, 1984.

${ }^{68}$ Department of Education, History Newsletter 6, 1984.

69 D. Wood, "Departmental Memorandum to the Minister of Education," July 13, 1987, R7 246 585, Archives New Zealand.

${ }^{70}$ R. Webb, personal interview, June 30, 2011.
} 
the issue at their Lopdell House meeting starting $29^{\text {th }}$ July, 1985. It was agreed that the implementation of the new curriculum, including the provision of "adequate teaching materials to schools", was the responsibility of the Department of Education. ${ }^{71}$

The Curriculum Development Division's response was to commission a set of 'H Documents'. These were to be guideline documents for teachers on various aspects of the curriculum's implementation. $^{72}$ H-Documents were planned on 'Form 6 History', 'Assessment', 'Special Studies', 'Women in History', 'Programme Planning', 'New Zealand Emphasis', 'Māori Dimension' and 'Learning Activities. ${ }^{73}$ Additionally, a timeline was drawn up for the development of student resource material booklets for some of the new topics. For the Year 12 course, these included 'Women, Family and Work in New Zealand', 'Participation of Women in the Emerging British Democratic System', 'Vietnam', 'Western Samoa' and 'Māori Leadership in the Nineteenth Century'. ${ }^{74}$ Thus work began on resourcing the curriculum.

Once again, factors outside of the control of the committee intervened. The Tomorrow's Schools reforms, including the demise of the Department's Curriculum Development Division and the position as Curriculum Officer History, were due to be enacted on $1^{\text {st }}$ October, 1989 - the same year that the new History syllabus was to be mandated for Year 12. This placed Wood and the committee under considerable pressure to get the curriculum resourced. ${ }^{75}$ In retrospect, Wood acknowledged that:

The Sixth Form Certificate [proposals] needed a little more investigation and deliberation, but such were difficult to carry out in the light of the momentous changes that were taking place. [They] introduced significant innovations [that] needed to be trialled thoroughly, to test the waters. There were experimental offerings which deserved more time. ${ }^{76}$

\footnotetext{
${ }^{71}$ Minutes from NHCC, July 29 - August 2, 1985, P. Lineham papers.

${ }^{72}$ Matters Arising - NHCC Meeting, Wellington, July 10-12, 1987," P. Lineham papers.

${ }^{73}$ Matters Arising - NHCC Meeting, Wellington, July 10-12, 1987," P. Lineham papers.

${ }^{74}$ Department of Education, Form Six History.

${ }^{75}$ D. Wood, personal interview, April 8, 2011.

${ }^{76}$ D. Wood, personal interview, April 8, 2011 (amended transcript).
} 
Some of the H-Documents were finished and were greatly appreciated by teachers. Paul Wulff returned from overseas in 1991 to take up a position as Head of History at Timaru College (now Mountainview High School). He described the teacher booklets as "immensely useful" as he organised a History programme in his new school. ${ }^{77}$ The Documents on 'Form 6 History', 'Assessment', 'Special Studies', 'Women in History', 'Programme Planning' and 'Computers and History' were commonly seen on the desks of teachers in resource rooms throughout New Zealand well into the 1990s. By the beginning of 1989, the student resource booklets on the new topics 'Women, Family and Work in New Zealand', 'Vietnam', 'The Search for Security in the Nuclear Age' could be purchased. ${ }^{78}$

Several other resources were unfinished or lost when the Department ended in October 1989 with the introduction of Tomorrow's Schools. Malama Meleisea and a team of teachers had been developing a topic outline and an accompanying resource booklet on the Western Samoa topic and submitted this to the Department in September. At that time, David Wood was leading a delegation of the Department at the OECD's Pacific Circle Consortium in British Colombia:

Effectively that took a month of my time, so I was not present at the 'change of the guard'. Knowing this, I had left instructions to Rex [Bloomfield] and his team to preserve the material on my desk till I came back. One of the instructions to the Departmental staff was that material found 'unclaimed' on the day of the transfer would be put in the bin and biffed. Sadly my instructions were not honoured and all of that work which Malama and others had done, the whole lot, was lost. It was tragic, and of course when I came back, I was no longer Education Officer History. There was no one left to steer the History process, and I was asked immediately to get on with policy projects. ${ }^{79}$

\footnotetext{
${ }^{77}$ P. Wulff, personal interview, June 29, 2011.

${ }^{78}$ Department of Education, Form Six History, 14.

${ }^{79}$ D. Wood, personal interview, April 8, 2011 (amended transcript).
} 
The equivalent resource on Māori Leadership in the Nineteenth Century also failed to materialise in time for distribution to schools. ${ }^{80}$

In a similar vein, Richard Webb was involved with a Department initiative which developed a computer database based on the passenger lists of the Edwin Fox immigrant ship which was being restored in Picton. An accompanying booklet demonstrated how a database could be used in a History classroom to develop critical thinking. Webb used the resource extensively with his students at Queen's High School in Dunedin, but the facility for distributing the resources to other schools ended with the Department. ${ }^{81}$

\section{Conclusion}

The Year 12 History programme aimed to respond to the changing nature of New Zealand society. It provided a skills focus, charging teachers with the responsibility of using History to prepare students for the information age. Teachers were encouraged to select a balance of topics from New Zealand, the Pacific, Asia and beyond and to include the perspectives of women and Māori within their programmes. At the same time, the curriculum retained all of the most popular topics which had been taught in the University Entrance era. This range of old and new topics, the introduction of internal assessment and the arrival of Tomorrow's Schools provided considerable autonomy for teachers, but they also removed the structures and resources which in the past had driven and supported curriculum change. In this sense, from 1989 Year 12 History teachers and students were 'caught in-between'.

\footnotetext{
${ }^{80}$ D. Wood, personal interview, April 8, 2011.

${ }^{81}$ R. Webb, personal interview, June 30, 2011.
} 


\section{Chapter Five}

\section{Year 12 History Encounters Sixth Form Certificate}

The culture of teaching can be as resistant to centrally imposed curricular initiatives as to any others. Where centrally initiated policies cohere with the existing culture of teaching, successful implementation is likely. ${ }^{1}$

Andy Hargreaves

\section{Introduction}

This chapter draws on oral evidence from thirteen teachers who taught History through the Sixth Form Certificate era (1986-2002) and were involved in the wider History teaching community at this time. It shows that while these teachers took advantage of the freedom associated with internal assessment to develop pedagogical approaches and assessment tasks which were engaging for students, resistance to new forms of History based on a narrow view of what constituted disciplinary History and a lack of resourcing and professional development, prevented them from selecting several of the new topics which were intended to help teachers and students fulfil the aims of the syllabus.

\section{Internal Assessment Freedom}

A curriculum is not 'implemented' in schools but 'recreated'; it is 'produced' rather than 'reproduced'. It is inevitable that educational mandates concerning curriculum and assessment are interpreted and adapted by teachers. This was particularly the case for teachers of Year 12 History in this study whose curriculum actively encouraged them to 'recreate' and 'produce' by providing them with a vast range of topic choices and therefore the autonomy to design a school-based curriculum within broad parameters. This chapter focuses on the 'operational' curriculum, which even in situations with less teacher autonomy than Year 12 History, can differ significantly from the 'intended' curriculum. ${ }^{3}$ Nesbit has outlined a series of conditions which need to exist if teachers are going to utilise change opportunities, such as those provided through internal assessment. Firstly, they

\footnotetext{
${ }^{1}$ Hargreaves, Curriculum and Assessment Reform, 67.

2 Apple, "Curriculum Planning," 25-41.

${ }^{3}$ McGee, Teachers and Curriculum Decision-Making.
} 
need to perceive an actual need. He stresses that new initiatives won't be taken up if they are seen to be imposed from the outside. Secondly, teachers need to be able to identify a range of alternatives that might meet the need. Finally, the school in which the teacher works needs to have a climate that is conducive to change. ${ }^{4}$

Even before the availability of the new curriculum in 1989, there were 13 topics available for teachers to choose from and the arrival of full internal assessment from 1986 increased the opportunity for teachers to pick a path for their students. ${ }^{5}$ Teachers, such as Logan Park High School's, Paul Enright discovered that it was the mode of assessment rather than the curriculum which provided him with flexibility. His first opportunity to teach a Year 12 History class coincided with the abolition of the University Entrance examination in 1986. When planning the year's programme, he abandoned the unsatisfactory and restrictive Year 12 textbooks, as there was no longer a content heavy examination to prepare students for. ${ }^{6}$

Like Enright, the majority of teachers who participated in this study embraced the arrival of internal assessment in Year 12 as an opportunity to free their programmes from external examination pressure. Mountainview High School's Paul Wulff recalls the feeling that he could design his own course as a "blossoming out." His teaching became less formulaic as a result:

There was a feeling that we could be much more creative... and bring different resources into the classroom to use. There wasn't the feeling that everything was rigid and set and that you had to follow much the same formula from day-to-day... When you are exam-focused, you are always [concerned] with what the latest exam questions were and where they seem to be going, but when you are freed up and given internal assessment, it enables you to be much more creative in designing activities that are going to get students' attention. ${ }^{7}$

\footnotetext{
${ }^{4}$ Cited in C. McGee, Teachers and Curriculum Decision-Making.

${ }^{5}$ See page 7.

${ }^{6}$ P. Enright, personal interview, June 30, 2011.

${ }^{7}$ P. Wulff, personal interview, June 29, 2011.
} 
Archival material supports the view of teachers that it was the assessment rather than curriculum change which transformed Year 12 History courses. Nicholas Tarling observed that the introduction of the internally assessed Sixth Form Certificate, three years prior to the introduction of the new curriculum, was causing teachers to consider curriculum possibilities that the 1989 document might not be able to contain:

Last week we had a meeting of the Auckland History Teachers' Association... The main topic was the mode of assessment for SFC in $1986 \ldots$ In the course of the discussion, I noticed that considerable diversity was clearly developing among schools and among subjects. This may turn out to be what is wanted in the longer term. But it seems to me that if it is accepted for 1986, it will be very difficult to draw back to a more uniform system if it turns out to be not what is wanted. ${ }^{8}$

Without the constraints of an external examination, teachers seemed to realise they could consider a range of new approaches. Additionally, they no longer felt they needed to cover every section of each topic in great detail, "just in case it came up in the examination." 9 While examination-focused courses were evenly divided up into a set number of topics of equal length, teachers in this study recall that the length of topics became quite fluid in the Sixth Form Certificate era. Carol Jarman, of Hamilton Girls' High School, was one teacher who found that internal assessment allowed her to contract and expand topics:

What it meant was that if you were teaching something and it was going really well, you could expand it out to a term... If it wasn't working so well you would spend two weeks on it and try something different... You could take a topic and think that part of it is really important and teach that and not worry about all the other things. ${ }^{10}$

There were some limitations on teacher autonomy with an internally assessed Sixth Form Certificate course. Teachers were required to submit documentation to the Department of Education's Examination Division and from 1990 to the New Zealand Qualification Authority,

\footnotetext{
${ }^{8}$ N. Tarling to J. Ross, October 1, 1985, R7 246 544, Archives New Zealand.

${ }^{9}$ S. Meffin, personal interview, May 24, 2011.

${ }^{10} \mathrm{C}$. Jarman, personal interview, May 26, 2011.
} 
where long-term contractor, Laurie Lord, had the task of approving the courses on the basis of their compliance with prescription and assessment requirements. ${ }^{11}$ Interviews indicate that it was not unusual for these documents to be returned to schools for reworking and resubmission, but teachers discovered that they could modify their course statements in order to comply without necessarily making the requisite changes to their assessment programmes:

We kept on getting it sent back because we would nudge up the [weighting of the] research component. We would be told we would need to give more to the [school] exams or the essays. So you would talk about 'document studies' and these sorts of things - an obtuse term for getting things through $!^{12}$

\section{New Pedagogical Approaches}

The absence of external assessment also provided the opportunity for more student activity and less teacher-talk. The Sixth Form Certificate History Prescription's requirement that all Year 12 students completed two research-based 'special studies' was particularly welcomed by those teachers who had been influenced by student-centred learning initiatives, such as those coming out of the United Kingdom's Schools Council History Project (SCHP). The SCHP had been significantly influenced by Bruner's metaphorical description of a discipline-based curriculum as a spiral had led to the development of activity-based and student-centred teaching approaches. By using the tools of academic historians within school programmes, it was believed that students could develop an understanding of the structure of an academic discipline, making learning more meaningful. ${ }^{13}$

Sheryll Ofner, who was the Head of History at Auckland Girls' Grammar School, was one teacher who was influenced by this aspect of disciplinary thinking. For her the "opportunity to turn kids on to being better historians" ${ }^{14}$ was the main reason she welcomed Sixth Form Certificate. Consequently, she designed a research task on the Russian Revolution in which students were required to take on the role of detectives, using historical evidence to

\footnotetext{
${ }^{11}$ L. Lord, personal interview, March 30, 2011.

${ }^{12}$ P. Enright, personal interview, June 30, 2011.

${ }^{13}$ Phillips, History Teaching.

${ }^{14}$ S. Ofner, personal interview, May 24, 2011.
} 
hypothesise about the final days of the Romanovs and the likelihood of Anastasia's survival. ${ }^{15}$

Other teachers chose the history of their school as the focus for their students' research. At Epsom Girls Grammar School, students recorded oral history interviews with former students as the basis for their major 'Special Study'. ${ }^{16}$ Palmerston North Boys' High School, a conservative provincial school whose leadership was suspicious of internal assessment, still utilised student research assignments as a key component of their Sixth Form Certificate History course in order to develop skills in their students and open up new areas for study. The focus of the research was the war experience of former students. Initially, the Rector's and Deputy Rector's fathers who had fought in the Second World War were studied, but later, students were required to find their own 'old boys' to research. The research unit included a trip to Wellington's Alexander Turnbull Library to access the military records of the soldiers they were investigating. ${ }^{17}$ In this instance, teacher autonomy and internal assessment provided the teacher with the opportunity to choose a topic which reinforced school tradition and was of interest to him.

The History Syllabus emphasised the importance of social history topics within the curriculum, but very little social history was taught in the examination courses of Years 11 and 13. Many schools found that student research was the best avenue through which to pursue this within the school History programme. At Hillcrest High School in Hamilton, History teachers Peter Thomas and Simon Dench used their connections with Age Concern to set up interviews with elderly people for their students to explore some social history. Hillcrest students were required to compare the experiences of their interviewee with those provided in the written historical record and evaluate the extent to which their interviewees' experiences were typical. ${ }^{18}$

Internally assessed research work also provided the opportunity for teachers to lead students on field trip work. This became a feature of the Year 12 programme at Timaru's

\footnotetext{
${ }^{15}$ S. Ofner, personal interview, May 24, 2011.

${ }^{16}$ M. Cotter, personal interview, May 25, 2011

${ }^{17}$ D. King, personal interview, April 12, 2011.

${ }^{18}$ S. Dench, personal interview, May 27, 2011.
} 
Mountainview High School where Paul Wulff developed a Central Otago gold rush field trip. ${ }^{19}$ From 1986 at St Paul's Collegiate, an independent school in Hamilton, History teacher Rodney Hamel drove a van-load of Year 12 students to Te Porere, a restored battle-site from Te Kooti's war of 1869, located near National Park. For their research work, the students were required to take Hamel's Te Porere model and choose a different historical site as the focus of their research. ${ }^{20}$

In some schools students were required to connect history to current events. In December 1987, Charmaine Poutney posted a copy of a History assignment written by a student at Auckland Girls' Grammar School to the Minister of Education, David Lange. She suggested that the work reflected the high "level of analytical thought and research skill being produced at this level" ${ }^{21}$ due to the introduction of internal assessment. The assignment task required students to choose a current issue in New Zealand society and research its historical origins. The student who produced this particular assignment, focused on the Fourth Labour Government's proposed closure of a large number of New Zealand's post offices. It concluded that "The closure of uneconomic post office agencies through corporatisation will ultimately benefit society." ${ }^{22}$ In his reply to Poutney, Lange explained that he "was impressed with the copy of the History assignment. It was thought provoking stuff." He had sent a copy to the Minister of State Owned Enterprises, Richard Prebble, "for his thoughtful consideration[!]"23

As well as legitimising research assignments, internal assessment opened up a range of possibilities for other types of assessment, although none of these were mandated. This study has uncovered a range of creative assessment tasks and pedagogical approaches, which appeared within History classrooms during the internally assessed Sixth Form Certificate era such as role play, student-led seminars and visual presentations. In at least three schools in this study, student role-play was a strategy used to develop student interest and historical empathy. Paul Wulff recalled that the assessment would revolve around

\footnotetext{
${ }^{19}$ P. Wulff, personal interview, June 29, 2011.

${ }^{20}$ R. Hamel, personal communication, November 23, 2011.

${ }^{21}$ C. Poutney to D. Lange, December 1, 1987, R7 246 574, Archives New Zealand.

${ }^{22}$ C. Poutney to D. Lange, December 1, 1987, R7 246 574, Archives New Zealand.

${ }^{23}$ D. Lange to C. Poutney, December 22, 1987, R7 246 574, Archives New Zealand.
} 
some written work which the students completed after the role-play. The role-play was a tool to develop understanding about historical issues and perspectives. ${ }^{24}$ At Hillcrest High School, Peter Thomas's students were required to give a speech in the role of an historical character as part of their Year 12 assessment programme:

I can remember [one student] delivering his speech as a Russian peasant dressed up in sack cloth, with a pitch fork, banging the floor. I can remember looking out this window here and seeing [another student] walking down here in an SS uniform and everyone else looking rather stunned as he walked into the room and sat down in the class and delivered his speech as a member of the Nazi SS. ${ }^{25}$

At Wellington's Onslow College, a more elaborate role playing exercise took place. Bruce Taylor remembers his History teaching colleague, Peter O'Neill and his Year 12 students reconstructing the assassination of the Archduke Franz Fedinand as part of their unit on the Origins of the First World War. The students devised a script, based on their research of the historical events, and used vintage cars in their re-enactment. The timetable was suspended so the rest of the students in the College could witness the 'assassination'. Taylor recalls that this activity "engendered a lot of enthusiasm amongst the students in Peter's class." ${ }^{26}$

A range of other Sixth Form Certificate class activities and assessment tasks that were designed to engage students were revealed by teachers through this study. These included: class debates ${ }^{27}$, student seminar presentations ${ }^{28}$, three-dimensional historical timelines ${ }^{29}$, student created board games ${ }^{30}$, children's story books based on historical themes ${ }^{31}$ and 'briefcase' or 'handbag' assignments in which students were required to recreate the contents of an historical figure's bag on a certain day in history. ${ }^{32}$ Such activities may have

\footnotetext{
${ }^{24}$ P. Wulff, personal interview, June 29, 2011.

${ }^{25}$ P. Thomas, personal interview, May 27, 2011.

${ }^{26}$ B. Taylor, personal interview, April 12, 2011.

${ }^{27}$ S. Meffin, personal interview, May 24, 2011.

${ }^{28} \mathrm{P}$. Thomas, personal interview, May 27, 2011.

${ }^{29}$ C. Jarman, personal interview, May 26, 2011.

${ }^{30} \mathrm{C}$. Jarman, personal interview, May 26, 2011.

${ }^{31}$ M. Cotter, personal interview, May 25, 2011.

${ }^{32}$ C. Jarman, personal interview, May 26, 2011.
} 
engaged students with the content of the course, but it is difficult to assess their effectiveness in developing historical understanding in the students who completed them. We have seen that over-assessment was a feature of the early Sixth Form Certificate period, when students were overly burdened with assignment tasks, which kept them busy, but did not necessarily contribute to their intellectual development.

Activities such as these featured prominently in the memories of several teachers in this study, but it cannot be assumed that these occurred in all schools. At Auckland Grammar School, the schemes for all 'conventional' Year 12 subjects consisted of three end-of-term examinations worth a total of 300 marks with a further 100 marks being generated by course or research work. ${ }^{33}$ The Palmerston North Boys' High School programme was similar. History teacher, Dominic King recalls that the majority of the Year 12 course's assessment came from the mid-year and final examinations, with the remainder generated from the research tasks. ${ }^{34}$ This continued emphasis on high-stakes examinations undermined the objectives of internal assessment and the History syllabus, which prioritised the development of disciplinary thinking through practical activities over memorisation. Perhaps, in these two traditional single sex boys' schools, wider school resistance to internal assessment may have hindered elements of change.

\section{Assessment}

One of the major objections to internal assessment was centred upon a perceived lack of consistency between schools. For History teachers, scepticism about the way in which 'the school down the road' conducted their assessment programme was fuelled by a series of NZQA audits into internal assessment practice at Year 13 level. From 1990, the Bursary History course had an internally assessed component, with forty per cent of the final mark generated from research work. ${ }^{35}$ In order to ensure fairness between schools, there were clear guidelines about the amount of time which was to be spent on this part of the course and restrictions on the topics which students could research. A 1997 audit into internal assessment practice at the Year 13 level was particularly damning. The reviewers reported a

\footnotetext{
${ }^{33}$ Interim Board of Studies Papers - 1987, R7 246 574, Archives New Zealand.

${ }^{34}$ D. King, personal interview, April 12, 2011.

${ }^{35}$ Marks submitted by schools for the internally assessed component of the course were scaled against the results of the external examination.
} 
"surprisingly high level of non-conformity to prescription requirements for special studies" and "wide variation of assessment standards." ${ }^{36}$

For many tasks it was virtually impossible to decide why marks had been given for tasks. In the absence of some statement of a standard, the marks seem to serve as a crude ranking device. Only three schools [out of ten] provided marking schedules... [In] One school... all the students' schedules added up to 100 but by various means, e.g. one student had 10 marks for the diary, another had 15 marks. Marks awarded for a bibliography ranged from no marks given, to 15 marks. ${ }^{37}$

The review concluded that "the variable allocation of class time to internal assessment tasks and the great inconsistency in assessment judgements, means serious questions need to be asked about the management of the internal assessment component of Bursary History." ${ }^{38}$ There was no comparable inquiry into assessment practices at Year 12 level; however, the experiences of moderators at the beginning of the standards-based era suggest that there was significant inter-school variation in the assessment practice and expertise of Year 12 History teachers. ${ }^{39}$

\section{Achievement Based Assessment (ABA)}

A lack of teacher expertise in assessment, and the system by which grades were predetermined by students' previous results in a different type of assessment, made the marking of Year 12 work problematic. One response to this was the development of Achievement Based Assessment criteria (ABA) for History. ABA had been identified in the Committee of Inquiry into Curriculum, Assessment and Qualifications' Second Report as a method of assessment which could replace the ranking of students in Sixth Form Certificate. $^{40}$ Before the end of the Department of Education in 1989, an extensive trial was undertaken in the use of $A B A$ for Geography. ${ }^{41}$ The development of $A B A$ for other subjects

\footnotetext{
36 "Evaluation of Internally Assessed Components," NZQA Circular CQ97/38S, NZQA Archives.

37 "Evaluation of Internally Assessed Components," NZQA Circular CQ97/38S, NZQA Archives.

38 "Evaluation of Internally Assessed Components," NZQA Circular CQ97/38S, NZQA Archives.

${ }^{39}$ C. Jarman, personal interview, May 26, 2011.

${ }^{40}$ Department of Education, Learning and Achieving.

${ }^{41}$ Department of Education, Report into Teacher Panel Moderation - SFC Geography.
} 
stalled with the introduction of Tomorrow's Schools; however, the New Zealand History Teachers Association took responsibility for its development. ${ }^{42}$

Through $A B A$, teachers were able to select the relevant skills for each of their tasks and use the ABA criteria as the basis for their marking. ${ }^{43}$ Of all the teachers in this study, only Carol Jarman and Sheryll Ofner made extensive use of ABA for Year 12 assessment. Jarman's introduction to ABA meets all of Nesbit's criteria for teacher change. After seeing the success which Geography teachers in her school were having with $A B A$, she attended a History ABA workshop. In her interview, Jarman recalled how appropriate the concept of $A B A$ and its criteria were for Sixth Form Certificate marking:

It seemed to make absolute sense that you could see those different stages and I quite liked the fact that you could use two or three criteria for pieces of work... You could identify different elements in students' work and say 'you're good at this but you need to work at that particular aspect a little more' ${ }^{44}$

Sheryll Ofner recalls the use of the criteria forcing her to explicitly think about the skills and concepts which were being covered in class. ${ }^{45}$ In doing so, this early form of standardsbased assessment appears to have helped to align the emphases of internal assessment tasks closely to the syllabus.

\section{Combined Schools Sixth Form External Examination}

In Chapter Three, we saw that some elite Auckland schools responded to the introduction of internal assessment at Year 12 level, by initiating their own set of 'external' examinations. Of the schools in this study, only Palmerston North Boys' High School took part in the External Examination for History. The decision to be involved was made by the Rector of

\footnotetext{
${ }^{42}$ S. Ofner, personal interview, May 24, 2011.

${ }^{43}$ The History ABA criteria were derived from the skills section of the Forms 5-7 History Syllabus with five levels of achievement described for each of eight history skill areas: 'Defining and planning an area of historical inquiry'; 'gathering information'; 'recalling historical knowledge'; 'understanding and using historical concepts'; 'analysing historical evidence'; 'understanding perspectives of people in the past'; 'constructing an historical argument' and 'communicating historical information.' See: Education Advisory Service, Achievement Based Assessment in History, C. Jarman Papers.

${ }^{44}$ C. Jarman, personal interview, May 26, 2011.

${ }^{45}$ S. Ofner, personal interview, May 24, 2011.
} 
the school, who had strong personal and professional connections with Auckland Grammar School. ${ }^{46}$ Despite this school-wide emphasis, History teacher, Dominic King recalls the examination was not prioritised by most of the Year 12 students who viewed the Sixth Form Certificate as having higher stakes:

[It was not] really very successful in terms of what the kids thought about it because there was no kudos with it. You didn't get credits for university or anything out of it, so while they would make an effort for Sixth Form Certificate, they didn't [put] a lot of effort into this exam. ${ }^{47}$

In its early years, the Sixth Form External Examination for History closely resembled the old University Entrance Examination. Students were asked resource interpretation, text comprehension and essay questions specific to the topics which they had studied. Many of the 'resource interpretation' questions were in reality questions which required content recall. For example, a resource-based question on the topic 'European State System 1815$1856^{\prime}$ from the 1988 paper provided candidates with a map of the Black Sea and the Crimea and then required them to "Name one West European power involved in the Crimean War" and identify the "Crimean port that was the scene of a lengthy siege." 48 These questions relied on student memory as none of this information required to answer them was contained within the source. The essay questions were also highly content specific. The question on the Russian Revolution in the same paper asked "What caused the events of Bloody Sunday and what were the consequences for the Tsarist regime?" 49

While this content specific approach was acceptable prior to the introduction of the 1989 prescription when the schools with students entered in the examination presumably studied a narrow range of topics, the proliferation of topics available to schools from 1989, made the setting of the examination problematic. Examiners were faced with the same dilemma which NCEA Level Two examiners faced from 2003 - how to assess a curriculum that was designed to be internally assessed with an external examination. Between 2000 and 2002,

\footnotetext{
${ }^{46}$ D. King, personal interview, April 12, 2011.

${ }^{47}$ D. King, personal interview, April 12, 2011.

${ }^{48}$ Combined Schools Sixth Form External Examination - History, 1988, D. King Papers.

${ }^{49}$ Combined Schools Sixth Form External Examination - History, 1988, D. King Papers.
} 
Dominic King was the examiner for History's External Examination. He recalls the examination being "an absolute devil to try and set." Given the wide variety of topics taught in schools "you had to work on the assumption that the students had no prior knowledge." His pragmatic response was to ask questions which were applicable to a range of topics. His 2002 paper provided a range of resources on South African history, a topic that none of the candidates had studied. The students were required to find the information to answer the questions from within the resources provided. For example, a graph showing exports of South African produce was used as the basis for the question "In which period did mining become South Africa's biggest export earner?"51

The External Examination's essay questions were organised around the prescription's four themes instead of each of its twenty-five topics. The 2002 examination included generic essay options such as "With reference to a topic you have studied, outline how nationalism emerged as a dominant force. Examine how this nationalism influenced the course of events nationally and/or internationally." ${ }^{52}$ This thematic approach was designed to allow students to access questions regardless of the specific topic they had studied, but in promoting the themes, it contradicted the curriculum designers' decision that themes were a guide for teacher planning and would not be explicitly assessed. These examples illustrate the difficulties of trying to impose an external examination structure on a broad disciplinebased syllabus which encouraged teacher autonomy in course design.

\section{Topic Choices after 1989}

Although the change in the External Examination question styles suggests that schools were teaching a wider-range of topics, it is not possible to categorically assess the extent to which schools ventured into the new topics once the 1989 prescription was mandated. The archive of Sixth Form Certificate course statements submitted to NZQA could not be located for this study ${ }^{53}$ and as we have seen, these may not have accurately reflected the operational curriculum of schools anyway. The lack of a nation-wide external examination

\footnotetext{
50 D. King, personal interview, April 12, 2011.

${ }^{51}$ Combined Schools Sixth Form External Examination - History, 2002, D, King Papers.

${ }^{52}$ Combined Schools Sixth Form External Examination - History, 2002, D. King Papers.

${ }^{53}$ Former NZQA contractor, Laurie Lord had agreed to help me locate this file at NZQA, but his death during the project hindered my efforts and those of current NZQA employees to find it.
} 
at this level has also hindered the collection of data on topic choice. However, the New Zealand History Teachers' Association's survey of their members in 2002 (Table One), in the final year of the Sixth Form Certificate era, indicates that apart from the topic on 'Vietnam and the Conflict in Indochina' only a small number of schools taught any of the new topics. In particular, the topics which were designed to expose students to women's and Māori perspectives and Pacific history aroused only minimal interest from teachers.

Table One

Year 12 History Topic Choices, $2002^{54}$

\begin{tabular}{|l|c|}
\hline Topic & $\begin{array}{c}\text { Number of } \\
\text { schools }\end{array}$ \\
\hline Origins of World War I & 155 \\
\hline Vietnam and the Conflict in Indo-China 1945-1975 & 146 \\
\hline Revolution in Russia & 139 \\
\hline The Weimar Republic and the Nazi State & 96 \\
\hline Gandhi and Indian Independence & 52 \\
\hline The Search for Security in the Nuclear Age 1945-present & 51 \\
\hline The Growth of New Zealand Identity 1890-1980 & 49 \\
\hline The American Revolution and the Making of the Republic 1774-1791 & 47 \\
\hline Bismarck and the Creation and Consolidation of the German State 1848-1879 & 23 \\
\hline The European States System 1814-1856 & 20 \\
\hline Women, Family and Work in New Zealand 1880-1960 & 15 \\
\hline Māori Leadership in the Nineteenth Century & 15 \\
\hline The Unification of Italy 1848-1881 & 13 \\
\hline Authority and Dissent in Australia 1788-1850s & 9 \\
\hline The First Industrial Society: Britain 1830-1870 & 8 \\
\hline New States in the South Pacific: The Case of Western Samoa & 4 \\
\hline Anti-imperialism in China 1884-1928 & 4 \\
\hline Japan's Decision to Industrialise and its Consequences 1867-1930 & 3 \\
\hline Participation of Women in the Emerging British Democratic System 1860-1930 & 3 \\
\hline From Colony to Nation: New Zealand Government 1840-1947 & 2 \\
\hline Small Power Conflict since 1945 & 2 \\
\hline New Zealand Economic Change and its Social Consequences 1879-1913 & 2 \\
\hline Case Studies in Industrial Cities & 0 \\
\hline The Making of Malaysia & 0 \\
\hline Rhodesia and Zimbabwe & \\
\hline
\end{tabular}

Researchers have stressed the high level of teacher autonomy present within the New Zealand education system which allows teachers to shut their classroom doors and ignore

\footnotetext{
54 “NZHTA Survey 2002 - Results," New Zealand History Teachers' Association Journal, November, $2002,35$.

${ }^{55} 235$ schools took part in the survey.
} 
the changes which are occurring around them. ${ }^{56} \mathrm{McGee}$ suggests that teachers are likely to make curriculum decisions based on their own interests and expertise rather than prioritising the needs of the students. ${ }^{57}$ Similar arguments have been made in the context of education reform in the United Kingdom, where teachers have been described as "present-oriented, conservative and individualistic." ${ }^{58}$ However, teacher apathy and vested interest do not sufficiently explain the topic choices made within Year 12 History in New Zealand. We have already seen that many of the teachers in this study embraced the arrival of internal assessment and the new pedagogical approaches which it released. This suggests that they were not simply resistant to all types of change. In her analysis of teacher surveys about the status of New Zealand history at Year 13, Bargas reported that teacher concerns around inadequate resourcing and student perceptions of New Zealand history dominated curriculum decisions. ${ }^{59}$ The interviews with the Year 12 History teachers in this study indicate that resourcing concerns and student interest, along with the historical interests and academic background of the teacher, were the main determinants of topic choice. Teacher perceptions about the status of different types of history seem to have also influenced their decisions.

The lack of resources specifically produced for the new topics in Year 12 History appears to have had a significant impact on topic choices. In Chapter Three, we saw that contestable resourcing contracts issued by the new Ministry of Education in the Tomorrow's Schools environment largely focused on the new Years 1-10 outcomes-based curriculum documents. Worse still, the proliferation of Year 12 topics and the relatively small number of students studying History at that level made textbook publication for many of the new topics an unattractive proposition to independent publishing houses. Apple has emphasised the negative aspects of textbook production in the United States, where they function as "the official arbiter of official knowledge." ${ }^{60}$ Even in New Zealand, at Year 12 level, where internal assessment and the high autonomy of teachers reduce the influence and necessity of official texts, teacher concern about of a lack of textbook resources remained.

\footnotetext{
${ }^{56}$ O’Neill, Clark and Openshaw, "Mapping the Field," 25-46.

${ }^{57}$ McGee, Teachers and Curriculum Decision-Making.

${ }^{58}$ Hargreaves, Curriculum and Assessment Reform, 54.

59 Bargas, "God Defend New Zealand."

${ }^{60}$ Apple, "Curriculum Planning", 26.
} 
In the interviews, teachers cited a lack of a suitable textbook as a major factor in decisions concerning the teaching of the Samoan topic. In Chapter Four we saw that the publication of a resource to support the topic's introduction was literally binned at the time of the introduction of the Tomorrow's Schools reforms in 1989. Teachers such as Howick College's Sharyn Meffin, found the combination of limited personal knowledge of Pacific history and a lack of resources was too big a hurdle to overcome. Other teachers did attempt to teach the topic but found that the lack of suitable resources made it difficult to sustain student interest. Malama Meleisea had written a general history of twentieth century Samoa which was published in $1987 .{ }^{61}$ Bruce Taylor attempted to use this book as the basis for Onlsow College student seminars on the topic, but found it to be inadequate for this purpose as it was primarily written for an academic audience rather than secondary school students. This discouraged Taylor from continuing with the topic. ${ }^{62}$ Logan Park High School History teacher, Paul Enright, had read books about Samoan history and considered introducing the topic. He recalled that difficulties associated with gathering appropriate material, at a time when he was feeling stretched by his responsibilities as Head of History discouraged him. ${ }^{63}$ Teachers also referred to other factors that hindered the introduction of the topic. At Hamilton Girls' High School, Carol Jarman felt that students from Pacific nations other than Samoa would not respond well to the introduction of the proposed topic. ${ }^{64}$

While teachers cited their hectic schedules, a lack of suitable resources, and wider school issues as the basis for not choosing the Samoan topic, other factors may also have been at play. Many of the textbooks which were used in the established topics were overly academic, text heavy and unattractive to students. It seems unlikely that such texts would discourage teachers from changing topics. For other topics, especially those externally examined in Year 13, teachers were prepared to commit themselves to large quantities of professional reading. Teachers' busy lives do not appear to have influenced topic choice in these situations. Perhaps the nature of the Samoan topic, with its emphasis on indigenous historical perspectives, clashed with teachers' perceptions of what constituted 'true history.'

\footnotetext{
${ }^{61}$ Meleisea, The Making of Modern Samoa.

62 B. Taylor, personal interview, April 12, 2011.

${ }^{63}$ P. Enright, personal interview, June 30, 2011.

${ }^{64}$ C. Jarman, personal interview, May 26, 2011.
} 
Its setting in a small Pacific Island nation may also have subconsciously discouraged teachers from selecting it. The disciplinary history which teachers had been exposed to in their own secondary and tertiary study is likely to have emphasised European settings, with extensive historiographical traditions which Samoan history could not replicate.

Like the Samoan topic, 'Māori Leadership in the Nineteenth Century' was designed to open up new areas of study for Year 12 History students and engage an underachieving group in their learning. In Chapter Four we saw that the radical idea behind this topic was that History teachers would develop partnerships with their local Iwi in order to identify key Māori leaders from the history of the area as the focus for study. The demise of the Department appears to have hindered the development of resources that supported this approach.

At one school in this study however, a topic evolved which in some respects reflected the intent of the curriculum designers. Logan Park High School in Dunedin had strong connections to Otago University and the Māori community. History teacher Paul Enright utilised the expertise of the school's Kaumatua and that of the parents of Kai Tahu students in developing the topic. Although officially entitled 'Māori Leadership in the Nineteenth Century", Enright recalls that they "extemporised what was in the syllabus" ${ }^{65}$, moving away from a focus on leadership to a more general history of Māori at the bottom of the South Island. The unit culminated with an assignment in which students could select their mode of presentation to illustrate an aspect of Kai Tahu history.

In a separate unit which required students to make an oral presentation about an historical figure, one of Enright's Māori students with whakapapa connections to key Kai Tahu leader, Tuhawaiki, spoke to his classmates about his ancestor. Paul Enright recalled his presentation:

He almost became him. He started with his whakapapa and mihi and we were into it... There was a whole other dimension to him that [the other students] hadn't seen.

${ }^{65}$ P. Enright, personal interview, June 30, 2011. 
There was Kelly, the intelligent, good humoured, very sociable sort [of guy] and all of a sudden, there was him with his culture at the forefront. ${ }^{66}$

In this case, the culture of the school, the teacher's connections and confidence and his openness to student autonomy appear to have created an environment where Māori history could be successfully studied within the curriculum, but in most schools these factors did not exist. The Waikato was the location for much of New Zealand's nineteenth century race relations conflict, with large areas of Māori owned land confiscated by the Crown at the conclusion of war. As a result tribal identity within the region was highly politicised. At Hamilton Girls' High School, division within the Māori community between members of the local Tainui Iwi and those from other tribes throughout the North Island dissuaded History teacher, Carol Jarman, who did not have close links with the local Iwi, from teaching the Māori Leadership topic. ${ }^{67}$

Most other teachers in this study did not seriously consider teaching the topic. Those that did used the autonomy provided by the curriculum and assessment to alter its focus away from that envisaged at the Gisborne hui. At Queen's High School in Dunedin, Richard Webb introduced a New Zealand topic to his students as soon as Year 12 had become internally assessed in 1986. He was conscious of the lack of New Zealand history in the programme and wasn't prepared to wait until 1989 to make changes to the course's content. From 1989 he altered the documentation of the course to reflect the new prescription. The outcome was "a New Zealand history overview under the guise of 'Māori Leadership'”. ${ }^{68} \mathrm{He}$ recalls covering material which focused on key Māori leaders, but essentially it was a "crash course in New Zealand [history]" ${ }^{\prime 69}$ Like Logan Park, Queen's High School had a strong connection with the local marae. Despite this, Webb didn't seriously consider utilising this within his course. Reflecting on his curriculum decision-making twenty years later, Webb suggested that the approach of the proposed topic was anathema to the rest of the curriculum and to his perceptions of the discipline of History at that time:

\footnotetext{
${ }^{66}$ P. Enright, personal interview, June 30, 2011.

${ }^{67}$ C. Jarman, personal interview, May 26, 2011.

${ }^{68}$ R. Webb, personal interview, June 30, 2011.

${ }^{69}$ R. Webb, personal interview, June 30, 2011.
} 
Queens under [Principal] Pat Harrison must have been one of the first schools of our sort to make a strong connection with the local marae, but I didn't pursue that [within this topic] and probably I should have. I suppose you've got a history set-up which is so rigid and full of politics and men and dates, the thought of going onto a marae and having an oral history of Māori that I didn't know anything about. I just didn't have enough confidence and faith that that was acceptable history. [At that time], that wasn't 'real' history. ${ }^{70}$

Webb's experience with Māori history reflects those of teacher participants in Manning's analysis of the teaching of History in a small sample of secondary schools in the Wellington region. Manning found that most teachers knew little about the iwi (Māori tribal) history of the area and felt ill-prepared to teach students about Māori history. He identified inadequate professional development, insufficient resources, professional rivalries and both student and parent prejudice as barriers to teachers adopting a place-based approach to teaching. ${ }^{71}$ Manning appears to underestimate the importance of perceptions about the discipline of History held by teachers, as illustrated by Webb, in shaping teacher decisions. It could be argued that in the case of History, Iwi approaches to the past do not sit comfortably with the views of many teachers about the critical disciplinary nature of their subject. This is not a central focus of the present study; however, further exploration of this area would be beneficial to the teaching and learning of History in Aotearoa/New Zealand.

From 1989, two topics which emphasised women's history were available for teachers to choose. One of these focused on 'Women, Family and Work in New Zealand 1880-1960', while the other centred upon the 'Participation of Women in the Emerging British Democratic System 1860-1930.' As with the Māori Leadership and Samoan topics, these received little in the way of sustained uptake from the schools in this study. There was however some movement into women's history in the 1986 to 1989 interregnum. This provides another example of teachers not waiting for permission from the new curriculum to develop a school-based programme. The History students at Logan Park High School were again the beneficiaries of such an initiative:

\footnotetext{
${ }^{70}$ R. Webb, personal interview, June 30, 2011.

${ }^{71}$ R. Manning, "The Status of Te Atiawa Histories."
} 
We did a forerunner of the Women, Family and Work in New Zealand [topic] but mainly based around the material you found in the 'Herstories' and... [through] using oral history. We used to do was to set a task... called 'A cross generational slice' where we would get [the students] to research employment or leisure or education. We would get them to talk to their grandmother, their mother and then to interview someone of their own age. ${ }^{72}$

Teachers recalled having less success when they attempted to introduce the prescribed topic when it became available from 1989. At Hamilton Girls' High School, Carol Jarman found that adherence to the Prescription's official version of 'Women, Family and Work in New Zealand' led her students to develop an unsatisfactory image of women in New Zealand history in which hard working white women dominated, with other women sidelined. ${ }^{73}$

Teachers from History departments in other schools abandoned the topic as a result of poor resources and a lack of student interest. Noeline Hannan recalled Hutt Valley High School boys "baulk[ing] at women's studies of any sort." She found it difficult to sustain student interest without textbook resources. ${ }^{74}$ The students at Palmerston North Boys' High School had a similar reaction. ${ }^{75}$ In both cases, the topic was rejected after its first year and replaced with topics on European political history. As History competed with other subjects for enrolments, especially in Year 12, student opinion had a powerful influence on their teachers' curriculum decision-making.

Carol Jarman was one of only two teachers within this study who selected the topic entitled: 'Participation of Women in the Emerging British Democratic System 1860-1930'. She has maintained an approach of selecting topics on the basis of their relevance to the lives of her students at Hamilton Girls' High School. This basis for topic choice has recently led Jarman to revisit the topic:

\footnotetext{
${ }^{72}$ P. Enright, personal interview, June 30, 2011.

${ }^{73}$ C. Jarman, personal interview, May 26, 2011.

${ }^{74}$ N. Hannan, personal interview, April 8, 2011.

${ }^{75}$ D. King, personal interview, April 12, 2011.
} 
I now teach [refugee] students who don't believe that women should vote... I stopped teaching [that topic] for a few years and three years ago I started teaching it again, because I felt as a personal value that it was important to say that women should vote... [It is also important] that other girls in the school realised that it was a really important issue. ${ }^{76}$

While most teachers in this study taught between four and six different topics throughout the Sixth Form Certificate era, Jarman taught eleven of the topics listed in the Prescription. In part, this is due to the independence she has from the set textbooks, which few of the other teachers in this study shared:

I am prepared to [create] all the resources myself. But, I enjoy that. If you said to me you could spend three hours tonight working on resources or an hour marking, I would go for resources every time. ${ }^{77}$

We have seen that there was little in the way of sustained uptake of the new topics. When a new topic did become established within a programme, this was often due to it being introduced in some form prior to the curriculum being mandated. In these cases, the introduction of the new topic was merely a rebranding of the existing topic for the purposes of compliance. When entirely new topics in Pacific, Māori or Women's history which challenged teachers' perceptions about the nature of History were introduced from scratch, without suitable text-based resources to support them, they struggled to gain traction in the face of negative student opinion.

What was different about the topic: 'Vietnam and the Conflict of Indochina'? After becoming available in 1989, this topic became firmly established throughout the country as one of the most commonly taught Year 12 topics. $^{78}$ Among the teachers in this study, it was the single-most popular taught topic during the Sixth Form Certificate era. Three factors

\footnotetext{
${ }^{76}$ C. Jarman, personal interview, May 26, 2011.

${ }^{77}$ C. Jarman, personal interview, May 26, 2011.

78 "NZHTA Survey 2002 - Results," New Zealand History Teachers' Association Journal, 32-38.
} 
seem to have influenced its selection. Firstly, the military and political emphasis of the topic meant that its selection did not represent a major shift. Although it was set in Asia, its themes of imperialism and military involvement were similar to the European topics which it replaced. In contrast, topics in Māori, Pacific and women's history, required teachers and students to consider alternative approaches to learning history and the utilisation of different sources for gaining knowledge.

A second major factor leading to its introduction was the availability of a suitable textbook written to reflect the New Zealand History Prescription. John Wood's textbook, Vietnam and the Indochina Conflict, ${ }^{79}$ was first published in 1990 . It is likely that this was the first commercially available textbook, specifically written for the New Zealand context on one of the new Year 12 topics. It was widely used. McCulloch and Richardson have suggested that an analysis of textbooks can provide information about the curriculum and teaching styles. ${ }^{80}$ This textbook followed a traditional approach, providing a grand narrative of the topic. While each chapter had a focusing question, which suggested an inquiry approach, little emphasis seems to have been placed on the contested nature of the topic or on the differing perspectives held by those involved in the topic's events. The book contained resource-based questions, designed to develop student understanding of the material covered in the text of the chapter, and review questions, designed to reinforce student content knowledge. ${ }^{81}$ In short, the textbook addressed the topic in a traditional manner with which teachers teaching political and military topics from European settings would be familiar.

It is important however, especially in light of the high autonomy environment in which the teachers using this book operated, not to simply assume that what was included in the text was always what was taught or learned. ${ }^{82}$ Many other lively resources were available on this relatively contemporary topic which many of the teachers in this study brought into the classroom. These included guest appearances from Vietnam War veterans, playing music and documentaries and the screening of Hollywood movies. The watching and analysing of

\footnotetext{
${ }^{79}$ Wood, Vietnam and the Indochina Conflict.

${ }^{80}$ McCulloch and Richardson, Historical Research in Education Settings.

${ }^{81}$ Wood, Vietnam and the Indochina Conflict.

${ }^{82}$ McCulloch and Richardson, Historical Research in Education Settings.
} 
movies became an important component of the topic in many history classes. At both Howick College and Logan Park High School, students were required to choose a film which focused on the Vietnam War and evaluate the extent to which it provided an accurate historical account

Finally, this topic also built on teacher interest and experience. The teachers in this study were from the 'Vietnam generation', with several participating in anti-war protests. Hargreaves has shown that teacher identity is established through the development of subject specific expertise developed through undergraduate training and individual study and interest. ${ }^{83}$ Personal memory provides teachers with stories which they can use to bring the history to life and enhance their teaching credentials. Hillcrest High School's Peter Thomas was typical of several participants:

'[Teachers] like me were part of that Vietnam generation. I can talk about my arguments with my father, protesting in the streets. I started university in [19]64. I remember the teach-ins, going on marches, arguing with my father - the first time I ever argued with my father. He was pro-Vietnam. I was anti-Vietnam. ${ }^{84}$

Thus, the Vietnam topic resonated with both teachers and students. There was also a wide range of resources which enhanced student interest and were easily accessible. These included the Vietnam textbook which was specifically written for Year 12 students in New Zealand. In comparison, the topics on Women's history, Māori Leadership and the history of Samoa lacked both the resonance and the resources.

\section{Local Courses}

In Chapter Three we saw that the Sixth Form Certificate regulations provided autonomy for teachers to move completely away from the constraints of the curriculum and develop 'local courses' which suited the needs of their school community. These courses could sit outside the established subject disciplines or cover alternative topics within an established

\footnotetext{
${ }^{83}$ Hargreaves, Curriculum and Assessment Reform.

${ }^{84} \mathrm{P}$. Thomas, personal interview, May 27, 2011.
} 
disciplinary framework. ${ }^{85}$ In many cases the main intention of local courses that teachers in this study were involved with, was to retain students within the Social Sciences learning area and guarantee continued employment for History teachers. Due to their reduced content they also provided increased opportunities for students to develop historical skills.

At Burnside High School, Paul O'Connor noticed the broadening of the school curriculum had the potential to take students away from History. His response was to develop a parallel History course called 'Social History'. The course involved topics focusing on New Zealand society during World War Two, family history and genealogy, 1960s society and a comparative topic looking at the Pacific gold rushes in Otago, Victoria and California. A research assignment within the local course involved students testing a hypothesis that the names of streets and other features within Christchurch were associated with early Pakeha settlers. In doing so, students ventured out of class matching street names with the names on headstones in local cemeteries. ${ }^{86}$

In terms of student numbers, the most successful local course revealed in this study was Hutt Valley High School's Year 12 'International Relations'. The proposal for this course submitted to the Department explained that this course was not intended to be an alternative to the conventional Year 12 History course. "Indeed it could be complimentary to it or provide a 'history type' option for students who have not previously taken History." ${ }^{87}$ The skills objectives outlined were "guided by the proposed 5-7 History Syllabus." ${ }^{88}$ The intention of the course was to make a contribution to the school's practice of developing alternative Sixth Form Certificate courses which would serve the needs of less able students. The History teachers believed that by selecting a setting with strong connections to current events, students of lower ability would find the content more accessible than the traditional course. However, the students who selected the course were quite different from those envisaged. Teacher, Noeline Hannan recalls that the International Relations classes were

\footnotetext{
${ }^{85}$ The 2002 NZHTA survey indicates that 15 schools had 'local' History courses - "NZHTA Survey 2002 Results", New Zealand History Teachers' Association Journal, 32-38.

${ }^{86}$ P. O'Connor, personal interview, June 28, 2011.

${ }^{87}$ Hutt Valley High School's Application - SFC International Relations, October 24, 1986, R7 246 558, Archives New Zealand.

${ }^{88}$ Hutt Valley High School's Application - SFC International Relations, October 24, 1986, R7 246 558, Archives New Zealand.
} 
regularly filled with able students (especially boys with a bent for Science), who selected the course as a sixth subject. ${ }^{89}$

The International Relations local course effectively took just one of the topics from the mainstream History programme (on the Cold War) and taught it for the whole year. This provided huge scope for a range of student-centred approaches. Hannan remembers allocating a continent to each group of students within the class. Each group was required to research the key events which had taken place within that continent in the preceding year and was then responsible for providing visual and oral presentations of this information to the rest of the class. ${ }^{90}$

Another activity required students to make documentaries about the historical background to current international relations issues which were broadcast on the school's fledgling television station. Hannan recalls that student enthusiasm for this task led to her receiving an extraordinary phone call which in turn led to a high profile class speaker:

I remember at one stage, students were doing anti-nuclear policy and they were keen to interview [Prime Minister] David Lange and one day I was at school and got a phone call. [There was] this very distinctive voice on the other end 'Lange here' and he said 'all these students of yours are wanting to come in and interview me. I've done three. I can't do any more... but l'll tell you what I can do. I can come out for an hour if you get them all in the same place' ... Lots of kids were around and they were all quite fascinated with the fact that he was here. There were a few murmurings from staff who lost some of their class for the spell. ${ }^{91}$

The high level of motivation which students were experiencing in the International Relations course had an impact on the teaching of the conventional History course. Although the content of Sixth Form History continued to be largely based around the pre-1989 topics on The European State System, The Unification of Germany, The Russian Revolution and Nazi

\footnotetext{
${ }^{89}$ N. Hannan, personal interview, April 8, 2011.

${ }^{90}$ N. Hannan, personal interview, April 8, 2011.

${ }^{91}$ N. Hannan, personal interview, April 8, 2011.
} 
and Weimar Germany, some of the successful learning activities from the International Relations course were transferred. In particular, more student centred research work was introduced to meet student demand and ensure that the conventional course wasn't cannibalised by the new one. ${ }^{92}$

\section{Conclusion}

The abolition of the University Entrance examination provided opportunities for History teachers to utilise new pedagogical approaches and in some cases explore new content areas that went beyond the scope of the existing curriculum. When a range of new topics were officially offered from 1989 , some teachers attempted to introduce some of them to their Year 12 courses. The Vietnam topic, reflected the themes and approaches of established European topics, was well resourced, and resonated with teachers and students. Topics which focused on the experiences of women, Māori and Pacific Islanders required major shifts in pedagogy, were poorly resourced, and failed to resonate with teachers and students. Thus 'Vietnam and the Conflict in Indochina' flourished while other new topics floundered. There were isolated examples of topics in women's and Māori history surviving more than one or two years, but in these cases the topics had been introduced prior to the introduction of the new syllabus and prescription, with the result being that the topics reflected the teacher's priorities rather than the curriculum's. As we saw in Chapter Three, from 1989, curriculum decisions were made within the context of the Tomorrow's Schools reforms when centralised resourcing and teacher professional development for History and other senior option subjects came to a sudden halt. The lack of centralised curriculum leadership and resourcing in History appear to have contributed to the lack of content change in Year 12 courses.

\footnotetext{
${ }^{92}$ N. Hannan, personal interview, April 8, 2011.
} 


\section{Chapter Six}

\section{Year 12 History Encounters Unit Standards}

"Warwick Elley described History and English as having a 'fuzzy logic.' Whereas unit standards are suited to [linear tasks]... History doesn't work like that. It's complete anathema to the philosophy of History." ${ }^{1}$

Peter Thomas, Hillcrest High School

\section{Introduction}

This chapter focuses on the impact of unit standards assessment on Year 12 History in the late 1990s. It highlights problems which were associated with imposing a standards-based framework on a broad syllabus which was discipline-based. It outlines the debates which occurred within the history community about the merits of an assessment system which assessed historical skills and concepts rather than historical knowledge. It is argued that the teachers who became involved in the unit standards trial made professional connections and received extensive professional development which equipped them to deliver an internally assessed, standards-based programme to their students and that those who decided not be involved, often for legitimate philosophical reasons, became isolated from important developments.

\section{History Unit Standards}

The task of applying a unit standards assessment framework to a broad discipline-based subject was problematic. For History, these problems were exacerbated by the subject's exclusion from the 1990s curriculum developments. The intention of the New Zealand Qualifications Authority was that the achievement objectives for levels 6-8 (Years $11-13$ ) of each of the Curriculum's learning areas would be the basis for the development of the new unit standards (Levels 1-3). ${ }^{2}$ However, the release of the outcomes-based curriculum for the Social Sciences was delayed until 1997, by which stage the unit standards were written and being trialled in schools. In the end, the final curriculum document bypassed the traditional senior subjects anyway, providing achievement objectives for Social Studies from Years 1-13, but leaving History (along with Geography and Economics) sitting outside of the core curriculum. The History unit standards writing panel was therefore confronted with a

\footnotetext{
${ }^{1}$ P. Thomas, personal interview, May 27, 2011.

${ }^{2}$ Wood, "The Political Origins of the NZCF."
} 
dilemma - how to go about developing a standards-based assessment system for a curriculum written under the assumptions of the Department of Education rather than the new Ministry and therefore not outcomes-based.

\section{Debates and Decisions}

The result was a philosophical debate which divided the history community. Sheryll Ofner, a History teacher from Selwyn College and chair of the Auckland History Teachers' Association, and who led NZQA's History Advisory Group recalls the division among the lead group over whether the History unit standards should be developed around specific historical topics or around generic historical skills and understandings which could be applied to different topics. ${ }^{3}$ Ofner had previously worked on the Achievement Based Assessment criteria for History. As a result, she was convinced that non-content specific concepts and skills could be extracted from the curriculum and used as the basis of standards-based assessment in History:

[Not] having the decontextualised [unit standards] wasn't going to work for History because you couldn't delineate standards. You had to get Level One, Level Two and Level Three. How can you do that with content? Just because you are studying the Russian Revolution doesn't mean that it is at Level One or Level Two. ${ }^{4}$

Others, including historian, Raewyn Dalziel, disagreed. They argued that in disciplinary history concepts were not easily transferrable, and could only be properly understood within a specific historical setting. ${ }^{5}$ Opponents of the 'skills and understandings' approach identified the concept of an 'arms race' as an example of the importance of context, suggesting that while in the Year 12 topic on the Cold War, an 'arms race' arguably prevented a World War, in the Origins of the First World War topic, an 'arms race' arguably caused one! ${ }^{6}$

\footnotetext{
${ }^{3}$ S. Ofner, personal interview, May 24, 2011.

${ }^{4}$ S. Ofner, personal interview, May 24, 2011.

${ }^{5}$ S. Ofner, personal interview, May 24, 2011.

6 Partington, "Social Studies in The New Zealand Curriculum," 83-102.
} 
Pragmatic considerations ultimately turned the debate in favour of what became known as the 'decontextualised' standards. Richard Webb from Dunedin's Queen's High School was another member of the Advisory Group. He recalls that the large number of topics available for Year 12 History made it impractical to develop content-based standards which would cover the whole curriculum:

So then the question was should we pick the half dozen most popular [topics]? ...We tried to find out what they were, but in the end there was always someone who was suicidal over the notion that some obscure topic was going to be dropped and we didn't have the courage to knock off any of them... Then it dawned on us, if we had generic standards, the teacher could do what they liked, and if they still wanted to do Rhodesia and Zimbabwe [for example, they could]. ${ }^{7}$

Teacher identity can be closely tied to teaching topics that they studied at school themselves, in their undergraduate degrees and during their teacher training. ${ }^{8}$ In making a decision to adopt an approach which would not result in any of the existing topics being axed, the Advisory Group avoided a confrontation with History teachers with their highly developed "culture of teaching." ${ }^{9}$ Within the committee, a compromise was reached through which both types of standards were registered, with the contextualised standards for Level 2 (Year 12) focusing on each of the four themes rather than each of the 25 topics.

\section{A Mismatch between Curriculum and Assessment}

Unit standards assessment required that the subject matter be broken into separate units. However, Year 12 History was based on a broad syllabus and a long-held belief that skills and knowledge were interrelated. Thus, there was a mismatch between the requirements of the assessment and the direction of the syllabus. The syllabus had framed historical skills as part of an on-going process in which historical information was gathered, processed and presented, ${ }^{10}$ but the unit standards categorised the skills into separate standards on

\footnotetext{
${ }^{7}$ R. Webb, personal interview, June 30, 2011.

${ }^{8}$ Hargreaves, Curriculum and Assessment Reform.

${ }^{9}$ Hargreaves, Curriculum and Assessment Reform, 56.

${ }^{10}$ Ministry of Education, History Forms 5 to 7 Syllabus, 8-9.
} 
research, source analysis and communication. ${ }^{11}$ There was no requirement that schools connect these together. ${ }^{12}$

The Syllabus explicitly stated that history skills were "interrelated" ${ }^{13}$, but within each unit standard, skills were isolated and assessed separately. This was particularly evident in the unit standard which focused on the examination of historical sources. In this case, the unit standards writers essentially lifted the bullet points which were under the heading of 'Information Processing' in the Sixth Form Certificate Prescription and turned these into criteria for the unit standard. ${ }^{14}$ Students were therefore required to answer a series of questions, based on sources, exhibiting a separate skill with each of their responses. As a result, 'historical relationships' such as the relationship between the past and the present, which had sat in the background of History programmes, were now brought to the forefront of assessment for national qualifications. One of the sample activities distributed to teachers in the unit standards trial reduced the concept of 'past and present' to a simple task of extracting information from sources from two different periods of history. Students were asked "Was grain supply more of a problem in helping to feed Russia's population in 1913 compared with during the nineteenth century? Use evidence from the tables to support your answer."15 Thus, an underpinning concept of disciplinary History, that the past informs the present, was reduced to a comprehension exercise.

Through the unit standards, the research process and the communication of historical information were separated. This meant that research skills were assessed in isolation from an end product, such as a research report. Historians conduct research as the first step to producing an argument which informs an understanding of the past, so the notion that research could be undertaken without the findings being developed into a presentation of any sort signalled a departure from the disciplinary approach. The flexibility provided by the unit standards allowed teachers to run these two standards together if they wished, and many did, but this made the assessment task unwieldy as assessment writers provided

\footnotetext{
${ }^{11}$ See NZQA, unit standards 5821, 5822 and 5823.

${ }^{12}$ NZQA, History Unit Standards Assessment Guide.

${ }^{13}$ Ministry of Education, History Forms 5 to 7 Syllabus, 8.

${ }^{14}$ Department of Education, Sixth Form History Course Statement; NZQA, Unit Standard 5822.

${ }^{15}$ NZQA, History Unit Standards Assessment Guide, 6.74.
} 
extensive instructions for students in the hope that they would be able to meet all the criteria required for both unit standards. ${ }^{16}$

\section{Opposition}

The teachers interviewed for this study remembered the unit standards arousing some hostile criticism. Dominic King remembers attending a meeting about the unit standards facilitated by Bruce Taylor, and along with his Palmerston North Boys' High School colleagues expressing very strong opposition to the unit standards. On reflection, King suggests that the cause of this opposition was a fear that the competitive environment in which his school thrived was being undermined:

We used to drive Bruce crazy, because he was trying to push unit standards... and we were a very vocal opposition to them in all the meetings we used to have... Being a school that achieved at a high level, selfishly, we wanted to guard our place at the top and I think that's the motivation behind it. ${ }^{17}$

The academic reputation of traditional, high decile, single sex schools, such as Palmerston North Boys High School was derived from students achieving excellent results in high-stakes public examinations. ${ }^{18}$ Through internal assessment and their lack of scaled percentage marks, the unit standards represented a significant threat to the status of this type of school.

At Hillcrest High School, History teachers initially got involved in the trial but withdrew due to philosophical concerns. These especially centred upon the pass/fail nature of unit standards assessment. Peter Thomas also argued that while the unit standards were suitable for linear tasks, they were unable to cater for the sophisticated nature of disciplinary History:

\footnotetext{
${ }^{16}$ For examples of dual assessment tasks, see NZQA, History Unit Standards Assessment Guide, 6.51-6.58 and 6.215-6.218.

${ }^{17}$ D. King, personal interview, April 12, 2011.

${ }^{18} \mathrm{M}$. Sheehan, “A Question of Bias?” 176-88.
} 
With the unit standards... you were going to pass or fail a student simply on a few facts. History is not like that. I think Warwick Elley described History and English as having a 'fuzzy logic' whereas unit standards are suited to [questions like] 'how do you erect a piece of scaffolding?' Lay out the scaffolding on the ground - first step. Second step - get these bits here, bolt these ones together. And you have to do it in a certain prescribed [order]. History doesn't work like that. It's complete anathema to the philosophy of history, especially the way that we teach it. ${ }^{19}$

Other schools remained indifferent to the development of standards-based assessment for History and played no part in their development in the 1990s. At Howick College, Sharyn Meffin recalls that the teachers in the History Department were of the view that unit standards were designed for less able students. As they already had local Sixth Form Certificate courses within the social sciences learning area targeted at these students, they chose to play no part in the trial of the unit standards. ${ }^{20}$ Similarly, Noeline Hannan remembers that it was not until the introduction of the National Certificate of Educational Achievement (NCEA) in the early 2000s that the Hutt Valley High School History Department encountered standards-based assessment. ${ }^{21}$

\section{Unit Standards Trial}

The remaining teachers within this study involved themselves in the trial in some capacity as they saw the unit standards as an opportunity to reshape their teaching programmes. For Paul Enright from Logan Park High School, the arrival of the unit standards provided a welcome opportunity to free his assessment programme from the flawed Sixth Form Certificate grading system. It was his view that many students studying History were not being awarded the Sixth Form Certificate grades which their work warranted. The unit standards would allow students to gain credit based on their work rather than their ranking. ${ }^{22}$

\footnotetext{
${ }^{19} \mathrm{P}$. Thomas, personal interview, May 27, 2011.

${ }^{20}$ S. Meffin, personal interview, May 24, 2011.

${ }^{21}$ N. Hannan, personal interview, April 8, 2011.

${ }^{22}$ P. Enright, personal interview, June 30, 2011.
} 
Robbins has suggested that successful educational change occurs when there is good communication between leaders and teachers, high quality education about the proposed changes, and involvement of teachers in the decision-making. ${ }^{23}$ The unit standards trials introduced participants to new ideas and then provided opportunities for them to have ongoing support from a full-time subject-based NZQA contractor and other History teaching colleagues. This was reminiscent of the way in which curriculum and assessment reform had functioned in the days of the Department. The History unit standards training began at the end of 1995 with a series of three-day professional development workshops held throughout the country. These were followed by four further one-day regional workshops (one each term in 1996) in which teachers met with the National History Facilitator, Paul $\mathrm{O}^{\prime}$ Connor, to discuss their experiences with unit standards and to share ideas. ${ }^{24} \mathrm{O}^{\prime}$ Connor was seconded from Burnside High School for the year to work on the NZQA contract. As well as facilitating the follow-up workshops, O'Connor's role involved the selection and editing of assessment tasks from the milestone submissions and distributing them to all the schools within the trial. ${ }^{25}$ At the end of the year, a substantial History Unit Standards Assessment Guide was compiled with advice for teachers on planning a unit standards programme, notes on the principles of standards-based assessment and 51 different sample assessment activities which had been generated from the trial. ${ }^{26}$

The participants in this study who took part in the trial have positive memories of their involvement. Like other History teachers, who had normally worked in isolation within their schools, Carol Jarman greatly valued the collaborative nature of the trial:

I think it was a fantastic opportunity, because... you met with other people who were teaching History and they were going through the same thing and you could work in a collaborative sort of way and at that stage I had never had the opportunity to work in my own school collaboratively with anybody. I had always worked by myself. It

\footnotetext{
${ }^{23}$ Cited in: McGee, Teachers and Curriculum Decision-Making.

${ }^{24}$ P. O'Connor, personal interview, June 28, 2011.

${ }^{25}$ P. O'Connor, personal interview, June 28, 2011.

${ }^{26}$ NZQA, History Unit Standards Assessment Guide.
} 
was a one-woman show... so I found externally to my own school a community of people. $^{27}$

This also had a positive impact on local History Teachers' Associations. Both Paul Enright and Paul Wulff recall the involvement in the unit standards built professional relationships between schools which lasted well beyond the trials in Otago and Aoraki respectively. Reflecting on the on-going impact of the unit standards trial in South Canterbury and North Otago, Paul Wulff explained that:

There has been a lot of co-operation between schools. Really, it is completely against the whole model of Tomorrow's Schools. Nonetheless, we have gone ahead and done it. That's been helpful because history teachers are often the only teacher [teaching history] in the school in most of these places. It's been helpful and uplifting for the teachers in the region, just being able to do that together. ${ }^{28}$

Involvement in a professional community through the unit standards trial both aided and hindered teacher autonomy. Paul Enright found that he could adopt ideas from other trial schools and adapt them to suit his own programme. One of the activities selected for the Assessment Guide, produced by a teacher from Waitaki Girls' High School, involved the assessment of a student field trip to the Burnside Homestead. ${ }^{29}$ This task provided a springboard for Enright to develop a field-trip, with an accompanying unit standards assessment, to the old fever hospital which sat on the hill above Logan Park High School. ${ }^{30}$ On the other hand, a sense of responsibility to contribute tasks which could be of use to other schools encouraged Enright to develop some of his locally derived teaching units into more conventional Sixth Form Certificate topics. For example, Logan Park High School's 'Cross-Generational Slice' oral history unit was reshaped to more closely reflect the prescribed outline for 'Women, Family and Work in New Zealand' and the topic which

\footnotetext{
${ }^{27}$ C. Jarman, personal interview, May 26, 2011.

${ }^{28}$ P. Wulff, personal interview, June 29, 2011.

${ }^{29}$ NZQA, History Unit Standards Assessment Guide, 6.137-6.140.

${ }^{30}$ P. Enright, personal interview, June 30, 2011.
} 
focused on Kai Tahu history in the south was reshaped into 'Māori Leadership in the Nineteenth Century. ${ }^{31}$

\section{Assessment Task Writing}

Much of the support and training focused upon assessment task design. ${ }^{32}$ Until the advent of the unit standards, internal assessment had involved teachers simply ranking students, with statistical moderation providing a range of grades or marks which could be allocated. The advent of the unit standards placed the onus on teachers to write and mark assessment tasks which would directly contribute to national qualifications. Carol Jarman recalled the difficulty in writing unit standards tasks for Hamilton Girls' High School students at the beginning of the trial:

I had this day off school to write an assessment. I was used to writing assessments. I had been doing it for a very long time and I sat down and I had the standard in front of me and I knew what I wanted and I thought this is so hard and I cried! I hardly ever cry about anything, but it just seemed really difficult. After a while, I pulled myself together and I got something reasonable out of it. ${ }^{33}$

While Sixth Form Certificate tasks had sometimes been quite open-ended and developed without close reference to the syllabus or prescription statements, unit standards tasks tied a task down to a series of tight criteria. Teachers found that they had to start with these criteria and develop a new task which explicitly allowed students to demonstrate the skills or understanding outlined in the unit standard rather than recycling an old task. ${ }^{34}$ Once teachers began writing unit standards tasks, they became very familiar with the content of the unit standards and the syllabus which it was based upon.

\section{Moderation}

The community aspect of the trial was enhanced through the development of a pre-task and post-assessment external moderation system. The development of a human as opposed to

\footnotetext{
${ }^{31}$ P. Enright, personal interview, June 30, 2011.

32 "Evaluation of Internally Assessed Components," NZQA Circular CQ97/38S, NZQA Archives.

${ }^{33}$ C. Jarman, personal interview, May 26, 2011.

${ }^{34}$ C. Jarman, personal interview, May 26, 2011.
} 
statistical moderation system was a significant development for teachers whose assessment up to that point had largely been hidden from the scrutiny of their colleagues. Within the unit standards trial community, moderation aided professional development. Carol Jarman, who moderated History assessment during the trial, remembers both joys and difficulties of the task:

...you were really getting your dirty linen public, because [in] Sixth Form Certificate, [assessment] was very much in-house. All of a sudden, some other person had to give you a tick on a piece of paper that what you were doing was alright and what you were accepting for student work was acceptable. But I feel, in some ways that that was some of the most useful work that I have ever done, because the people who were [in the trial] actually wanted the best for their students and you could have such useful conversations with them... It [also] had the opposite effect; I did have people ring me up at home and shout at me because they were unhappy about something I had said. It was interesting I suppose. There were strong emotions involved. ${ }^{35}$

\section{Unit Standards and Year 12 History}

It is difficult to categorically assess the impact of the unit standards trial on teaching and learning in Year 12 History. Seven of the teachers within this study were involved in the unit standards development at a high level $^{36}$ and this strong personal investment may have enhanced their positive memories of the impact of the trial. Also, in most trial schools, instead of replacing Sixth Form Certificate, the unit standards and the existing qualification coexisted. This makes it difficult to evaluate the impact of the unit standards alone on student interest and motivation. Nonetheless, a few observations are outlined here based on the teacher interviews and analysis of a limited number of documentary sources.

\footnotetext{
${ }^{35}$ C. Jarman, personal interview, May 26, 2011.

${ }^{36}$ Bruce Taylor, Sheryll Ofner, Richard Webb and Paul O'Connor all had input into the writing of the standards at different times, with Ofner, Webb and O'Connor also involved with training other teachers in teacher workshops. Carol Jarman and Paul Enright were contracted to be moderators during the trial. Paul Wulff, Jarman and Webb all had assessment tasks selected by Paul O'Connor for inclusion in the Assessment Guide for distribution to other schools.
} 
Two teachers specifically recalled that the work submitted by their students for unit standards assessment was of a higher quality than the work which they had previously received for Sixth Form Certificate. ${ }^{37}$ Margaret Cotter remembered that this was particularly evident with regards to the students' essay writing. ${ }^{38}$ Richard Webb explained that this improvement was a consequence of the more detailed task instructions which teachers were issuing to their students. ${ }^{39}$ In the case of formal essay writing, structure was now an integral part of the assessment. Students who failed to provide an introduction, a conclusion or a series of well-structured paragraphs did not gain the unit standard. ${ }^{40}$ Teachers adjusted their task instructions and their teaching to emphasise this and the quality of student work appears to have improved as a consequence. Webb also observed that the nature of student research work changed, with the unit standards forcing teachers to bring the research process to the forefront of their teaching and task design. ${ }^{41}$ While, under Sixth Form Certificate assessment, it was common for teachers to issue tasks which solely assessed the quality of the written work which resulted from the research, ${ }^{42}$ under the unit standards method, students were required to define a topic for study, formulate a research plan, select relevant evidence from at least four different sources, record the source details and organise the researched information according to a system. ${ }^{43}$ Thus the assessment tasks were directing the students much more explicitly towards the skills section of the syllabus than had previously been the case under the high teacher autonomy combination of Sixth Form Certificate History's curriculum and assessment.

Some opponents of the introduction of unit standards argued that through their basic pass/fail mechanism, they 'dumbed down' student achievement and ambition. However, three teachers in this study found that they could utilise the decontextualised unit standards to provide opportunities for students within the same class to work at different curriculum levels. A student, for example, who successfully wrote a Level Two (Year 12) essay on their first attempt, could attempt a Level Three (Year 13) essay later in the year,

\footnotetext{
${ }^{37}$ M. Cotter, personal interview, May 25, 2011; R. Webb, personal interview, June 30, 2011.

${ }^{38}$ M. Cotter, personal interview, May 25, 2011.

${ }^{39} \mathrm{R}$. Webb, personal interview, June 30, 2011.

${ }^{40}$ NZQA, Unit Standard 5823.

${ }^{41}$ R. Webb, personal interview, June 30, 2011.

${ }^{42}$ e.g., P. Thomas, personal interview, May 27, 2011.

${ }^{43}$ NZQA, Unit Standard 5821.
} 
while other students continued working towards Level 2. As the majority of unit standards were generic rather than content specific, a student could continue studying the same content as the rest of the class, but be assessed at a higher level. ${ }^{44}$ The sample assessment activities contained in the History Unit Standards Assessment Guide modelled this approach with three similar tasks provided on an aspect of Australian history, with each task assessing the 'historical force' unit standard from a different level. ${ }^{45}$ This approach was utilised in a small number of schools. For example, a Burnside High School task selected for the Guide assessed student understanding of the Gulf of Tonkin incident from the Vietnam War topic (usually taught at Year 12) using a Level 3 (Year 13) unit standard. ${ }^{46}$ The multi-level approach was also utilised at Logan Park High School. Paul Enright recalled that this flexibility aligned with his philosophy of assessing students in a manner and at a time which best suited them:

The first year I [used the unit standards] I had three or four really talented students who bowled everything over first time through, so by the end of the year I was giving them Level Threes... At the time the trial was scrapped, we had started offering the other way as well, bringing kids who came in and hadn't done History before the chance to do Level One. All of the research around timeliness of education, about teaching students where they were at, seemed to mesh so much more with [the unit standards] than anything that we had done before. I became a bit of a zealot! ${ }^{47}$

The unit standards themselves appear to have had little impact on teacher topic choice for Year 12 History. According to teachers in this study, any decisions made to change topics at this time were not based on assessment considerations. The History Unit Standards Guide contains sample tasks from a range of topics from the Sixth Form Certificate Prescription, including topics introduced in both the UE and Sixth Form Certificate era, ${ }^{48}$ but as the tasks were selected to demonstrate assessment rather than curriculum practice, we cannot assume that they are representative of the topics utilised within the trial. They do appear to

\footnotetext{
${ }^{44}$ P. Enright, personal interview, June 30, 2011.

${ }^{45}$ NZQA, History Unit Standards Assessment Guide, 6.105-6.135

${ }^{46}$ NZQA, History Unit Standards Assessment Guide, 6.259-6.262.

${ }^{47}$ P. Enright, personal interview, June 30, 2011.

${ }^{48}$ NZQA, History Unit Standards Assessment Guide.
} 
indicate however, that the decontextualised unit standards were more widely used than the thematic unit standards, with teachers using the content of their topics as the basis of skillbased assessments. ${ }^{49}$

\section{Conclusion}

The debates around the merits of internally assessed standards-based assessment appear to have divided the History teaching community. The teachers in this study, who were opposed to the unit standards, objected to the fragmentation of the discipline into disconnected components, the apparent relegation of the importance of historical content and the corresponding over-emphasis on process and skills. Of particular concern was the simple pass/fail mechanism by which the unit standards were assessed. Those teachers in this study who became involved in the trials remember that although some of their previous Sixth Form Certificate assessment tasks were no longer applicable, their new tasks tied the assessment more tightly to the skills and concepts of the curriculum, with the quality of student work improving as a consequence. Those heavily involved in the trial found that they could effectively use the unit standards to provide multi-level assessment opportunities within their Year 12 classes. Significantly, teachers in the trial received release time and subject-specialist support from NZQA contracted facilitators, moderators and their colleagues in other schools. One outcome was the development of community expertise in assessment task writing for a standards-based system. While, this expertise would serve these teachers well when the whole country moved to a standards-based system in 2003 , many of those outside the trial were underprepared and, as we shall see in Chapter Seven, as a result, they struggled to develop school-based curriculum and assessment programmes in the new environment.

\footnotetext{
${ }^{49}$ NZQA, History Unit Standards Assessment Guide.
} 


\section{Chapter 7}

\section{Year 12 History Encounters Achievement Standards}

"The influence of examinations or standardized testing on classroom pedagogy, the effects of tightly bounded subject communities on attempts to implement crosscurricular change... limited amount of statutory time for rigorous, sustained and collective reflection about educational issues - all these things are indispensible items on any agenda for substantial innovation."11

Andy Hargreaves

\section{Introduction}

The NCEA, used to assess Year 12 History from 2003, was a political compromise. The standards-based approach of the unit standards was retained, but with three levels of achievement ('Achieved', 'Achieved with Merit', and 'Achieved with Excellence'), unlike the unit standards which were awarded on a simple pass/fail basis. For most subjects, at least half of the NCEA's achievement standards were also now to be externally assessed. For Year 12 this was a significant change as this level had been completely internally assessed since 1986. This chapter deconstructs the Level Two History achievement standards, and explores the experiences of History teachers as they grappled with them at Year 12 level between 2003 and 2005. It suggests that those who had developed assessment expertise during the unit standards trial period were largely successful in implementing the internally assessed component of NCEA Level Two History. Those who had not been part of the History unit standards professional community struggled to put in place a standards-based internal assessment programme to suit the needs of students in their schools. This chapter also describes the difficulties which were associated with assessing a curriculum which encompassed a vast range of topics as a legacy of the liberalisation of internal assessment, within the format of an external examination. I will argue that the generic approach which emerged as the solution to this problem was unsuitable for assessing disciplinary History.

\section{Achievement Standards Development}

The introduction of external assessment appears to have moved the History standards further away from the intent of the syllabus than the unit standards had. With the unit

\footnotetext{
${ }^{1}$ Hargreaves, Curriculum and Assessment Reform, 61.
} 
standards, the requirement that students complete an essay and another form of presentation to gain one unit standard was onerous for students but it reflected the desire of the standards writers to be faithful to the 'Skills Objectives' of the History Forms 5 to 7 Syllabus for Schools which emphasised a three step-process of gathering, processing and presenting historical information. ${ }^{2}$ Since the essay and the other mode of communication were both forms for presenting historical information, they were combined into the same unit standard. ${ }^{3}$ The requirement that the achievement standards developers nominate particular standards for external assessment led to a split of the presentation skill into two distinct standards, with formal essay writing to be externally assessed ${ }^{4}$ and the communication of historical ideas in other forms internally assessed. ${ }^{5}$

Through the requirements of one of the externally assessed essay writing standards, students were required to "examine a force or movement that influenced people's lives." The concept of an 'historical force' appears to have been derived from the description of the themes in the Forms 5 to 7 History Syllabus, which stated that "Form 6 History introduces the student to some of the major factors which have shaped today's world." ${ }^{7}$ Among a list of nine considerations under the umbrella of 'Programme Planning' in the 1989 Syllabus teachers were encouraged to "focus on people as well as on forces or movements." ${ }^{8}$ The Sixth Form Certificate History Prescription had also drawn on this idea when it described the Year 12 programme's focus "on some of the major forces shaping the modern world." Nonetheless, the use of this overarching concept as an explicit basis for awarding national qualifications represented a major shift for Year 12 History programmes.

\footnotetext{
${ }^{2}$ Ministry of Education, History Forms 5 to 7 Syllabus for Schools.

${ }^{3}$ There were separate unit standards on 'Define and Plan an Historical Investigation under Supervision' (NZQA, US5821), 'Examine Historical Sources' (NZQA, US5822) and 'Communicate Historical Information in an Essay and another Mode (NZQA, US5823). These reflected the 'Information Gathering', 'Information Processing' and 'Presentation' skills objectives of: Ministry of Education, History Forms 5-7 Syllabus for Schools.

${ }^{4}$ Two separate standards assessed essay writing: NZQA, Achievement Standard 90469; NZQA, Achievement Standard 90470. Both these standards were assessed in an external examination.

${ }^{5}$ NZQA, Achievement Standard 90466.

${ }^{6}$ NZQA, Achievement Standard 90469.

${ }^{7}$ Ministry of Education, History Forms 5 to 7 Syllabus, 10.

${ }^{8}$ Ministry of Education, History Forms 5 to 7 Syllabus, 14. (Emphases added)

${ }^{9}$ Department of Education, Sixth Form Certificate History Course Statement. (Emphasis added.)
} 
While teachers who were familiar with the language of the curriculum documentation and the unit standards may have felt comfortable with the notion of 'historical forces' having an impact on history, the curriculum connection of the other Level Two History essay writing achievement standard was unclear. One achievement standard focused on the development and expression of 'individual or group identity' in history. As with the other standards, the writers claimed that the content of AS90470 was "related to the major aims and objectives identified by [the] History, Forms 5 to 7 Syllabus for Schools. "10 However, the concept of 'identity' as stated in the Syllabus related to the students themselves rather than the content of their course. In its statement under the heading 'The Place of History in Schools', the syllabus explained that "history contributes to students' understanding of their culture, heritage and identity."11 The syllabus for all levels did refer to "the contribution of individuals" to history and emphasised 'nationalism' and other concepts related to 'identity', but the development of a specific standard which examined individual or group identity, promoted this concept well beyond the scope of the written curriculum for Year 12 History. Although not explicit in the written curriculum documentation, the concept of 'national identity' was an important theme in the writing of New Zealand history in the 1980s, with historians Keith Sinclair ${ }^{12}$ and Michael King ${ }^{13}$ prominent in arguing a case for the distinct nature of New Zealand's past. 'Identity' also featured prominently in the 'Culture and Heritage' strand of Social Studies in the New Zealand Curriculum. ${ }^{14}$ It appears as if these influences, rather than the existing curriculum statements, encouraged the standards writers to focus this externally assessed achievement standard on the concept of individual and group identity.

The uptake of the thematic-based unit standards had been limited. ${ }^{15}$ Subsequently, there were no specific achievement standards which focused solely on the themes. However, the 'explanatory notes' of the externally assessed standards referred to the themes, with the topics from the Sixth Form Certificate History Prescription contained in the appendix to the

\footnotetext{
${ }^{10}$ NZQA, Achievement Standard 90470, 2.

${ }^{11}$ Ministry of Education, History Forms 5 to 7 Syllabus, 5. (Emphasis added)

${ }^{12}$ Sinclair, A Destiny Apart.

${ }^{13}$ King, Being Pakeha.

${ }^{14}$ Ministry of Education, Social Studies in the New Zealand Curriculum.

${ }^{15} 27$ Level Two activities were selected from the trial for inclusion in NZQA's The Unit Standards History Assessment Guide. Only one of these tasks was based on a thematic standard.
} 
standards. A surprising development was the addition of five new topics focusing on elements of Māori history. ${ }^{16}$ These seem to have come about at the insistence of the Ministry of Education, that the standards would be applicable to students and teachers in Kura Kaupapa (Māori immersion) schools. There is no documentary evidence or recollection from the teachers interviewed in this study that there was any consultation with teachers in English medium schools about these new topics. Nor were any new resources developed to support the topics. Unsurprisingly, none of the teachers in this study selected any of these new topics for the students in their schools. The new topics increased the number available within the Year 12 History 'curriculum' from 25 to 30 and further increased the diversity of the topics available. This made the task of writing standards and external assessment tasks which could be applied to each of them even more difficult.

While each unit standard provided one set of criteria which a student had to demonstrate to be awarded the standard, the philosophy of the National Certificate in Educational Achievement required each achievement standard to provide three sets of criteria so that a grade of either 'achieved', 'merit' or 'excellence' could be awarded. This was problematic due to the fact that there were also three levels of standards. The writers of the Level Two standards had to ensure that the language used to describe all levels of achievement required more of the students than the Level One standards did, but they also had to ensure that some higher level verbs were held back for the Level Three standards. Furthermore, research indicates that progression in History is complex and that historical skills and dispositions do not necessarily progress in a linear fashion which allows them to be measured. ${ }^{17}$ Achievement standard 90467, which was to be used in the assessment of students' historical source analysis skills, provides an example of how the standard writers used a combination of quantitative and qualitative measures to differentiate the levels of achievement. Table two shows that the first skill, the identification of facts, ideas and points of view, was to be measured quantitatively through the first set of criteria, the second set combined quantitative and qualitative measures, with the third skill being assessed qualitatively: $:^{18}$

\footnotetext{
16 "Clarification of the Format and Topics," SecQual S2003/083, 4 October, 2003, NZQA Archives.

${ }^{17}$ Lee and Ashby, "Progression in Historical Understanding," 199-222.

${ }^{18}$ NZQA, Achievement Standard 90467, p2. (Emphases added)
} 
Table Two

Achievement Standard 90467 - Examine evidence in historical sources

\begin{tabular}{|l|l|l|}
\hline \multicolumn{1}{|c|}{ Achievement } & \multicolumn{1}{|c|}{ Achievement with Merit } & \multicolumn{1}{c|}{ Achievement with Excellence } \\
\hline $\begin{array}{l}\text { Identify some historical facts, } \\
\text { ideas and points of view } \\
\text { indicated by the evidence } \\
\text { provided. }\end{array}$ & $\begin{array}{l}\text { Identify most historical facts, } \\
\text { ideas and points of view } \\
\text { indicated by the evidence } \\
\text { provided. }\end{array}$ & $\begin{array}{l}\text { Consistently identify historical } \\
\text { facts, ideas and points of view } \\
\text { indicated by the evidence } \\
\text { provided. }\end{array}$ \\
\hline $\begin{array}{l}\text { Identify and describe some } \\
\text { historical relationships } \\
\text { indicated by the evidence } \\
\text { provided. }\end{array}$ & $\begin{array}{l}\text { Identify and describe most } \\
\text { historical relationships } \\
\text { indicated by the evidence } \\
\text { provided. }\end{array}$ & $\begin{array}{l}\text { Provide an informed and } \\
\text { perceptive explanation of the } \\
\text { historical relationships } \\
\text { indicated by the evidence } \\
\text { provided. }\end{array}$ \\
\hline $\begin{array}{l}\text { Make valid judgement(s) } \\
\text { and/or generalisation(s) about } \\
\text { the usefulness and/or reliability } \\
\text { of the evidence provided }\end{array}$ & $\begin{array}{l}\text { Make valid judgement(s) } \\
\text { and/or generalisation(s) about } \\
\text { the usefulness and/or reliability } \\
\text { of the evidence provided }\end{array}$ & $\begin{array}{l}\text { Make valid and perceptive } \\
\text { judgement/s) and/or } \\
\text { generalisation(s) about the } \\
\text { usefulness and/or reliability of } \\
\text { the evidence provided }\end{array}$ \\
\hline
\end{tabular}

\section{NCEA Level 2 History Professional Development}

The combination of qualitative and quantitative measures even within a single achievement standard is indicative of the complexities involved with assessing student work against achievement standards and underlined the importance of sufficient training for teachers. Throughout the NCEA implementation period, the Ministry of Education mandated a series of Jumbo Days in which schools were closed and teachers gathered in subject groups to work through the training material together. Two 'Jumbo Days' were specifically dedicated to Level Two History; one during Term 4, 2002 and a second during Term 2, 2003. ${ }^{19}$

While the emphasis of the unit standards training had been on the writing of standardsbased assessment tasks, the NCEA Jumbo Days focused almost entirely on teacher marking of student work for internal assessment. ${ }^{20}$ The training material included some analysis of the internally assessed achievement standards and then provided participants with the opportunity to practice making assessment judgements about the quality of student work. This proved to be problematic as the student work which had been generated for the training material was based on draft achievement standards which had been altered

\footnotetext{
${ }^{19}$ Industrial action taken by PPTA members during 2002, delayed these workshops which were originally scheduled for earlier in 2002.

${ }^{20}$ Ministry of Education, NCEA Level Two History Professional Development Handbook.
} 
significantly by the time of the workshops. ${ }^{21}$ In some regions, this led to some heated disagreements about what grade a student should be awarded and dissatisfaction with the quality of the training material. ${ }^{22}$ This process of developing a consensus around the grading of student work appears to have been more difficult at Level 2 than the other levels of NCEA due to the wide variety of Year 12 assessment programmes that existed in schools and the lack of a national examination at this level for the previous 17 years.

\section{Internal Assessment}

The two Jumbo Days, on their own, cannot have adequately prepared teachers for the task of writing assessments and assessment schedules for a Year 12 school-based History curriculum. At the end of the first training day, there was a short session dedicated to the development of assessment tasks, but only very general guidelines were provided for teachers, with the emphasis placed on workshop participants familiarising themselves with the tasks which were available for download from the Ministry of Education teacher support website. ${ }^{23}$ The writing of assessment tasks was a complex undertaking, with elaborate task instructions required for students, accompanied by detailed assessment schedules, outlining the types of evidence required by markers and moderators for 'Achieved', 'Merit' and 'Excellence'. One of the exemplar tasks provided for the training was seven pages long. ${ }^{24}$ This was not unusual. Consequently many teachers appear to have chosen not write their own tasks, or at best make only minor changes to an 'official' task to make it fit with a topic they taught. The requirement that assessment schedules anticipate the types of answers students might produce at the various grade levels, particularly discouraged Hillcrest High School's Peter Thomas from developing his own tasks:

You have to pretend that you know what a student is going to write for an 'achieved' and then you throw in a few more adjectives and a few more facts and say this is at 'merit' level and here's an 'excellence' one. I have never seen so much crap in my life. $^{25}$

\footnotetext{
${ }^{21}$ Ministry of Education, NCEA Level Two History Professional Development Handbook.

22 B. Taylor, personal interview, April 12, 2011

${ }^{23}$ Ministry of Education, NCEA Level Two Professional Development Handbook, 50.

${ }^{24}$ Ministry of Education, NCEA Level Two Professional Development Handbook, 8-14.

${ }^{25}$ P. Thomas, personal interview, May 27, 2011.
} 
At Howick College, Sharyn Meffin found that many of the creative activities which had been assessed in the Sixth Form Certificate History programme were dispensed with and replaced by tasks which closely resembled those in the exemplars:

Those creative activities kind of disappeared when NCEA came. When we had to set an internal assessment of a certain nature, we changed them. For a start, we didn't know anything about how it was going to work, so we took the exemplars we had... and we started again. How was I going to [set] a Vietnam Film Study, which was going to be... tie[d] down to the sort of assessment schedules they were talking about? There were so many criteria and they were so hard to fit existing assessments into. We were concerned that we would be doing the wrong thing and we would be in trouble. ${ }^{26}$

At Howick College and Hillcrest High School students had previously dramatised historical perspectives of history for assessment, but this performance aspect was downplayed in the NCEA era. ${ }^{27}$ Peter Thomas explained that it was the requirements of assessment and moderation which discouraged him from continuing his practice of students presenting a speech in the role of an historical figure:

"Now they just write an imaginary speech... [NZQA] would require us to evaluate it and film it and send that down to be moderated and I would be judging it on the way the kid performed it. [It is] utterly irrelevant. That's Media Studies. I am not a Media Studies teacher." 28

The high teacher autonomy schooling environment which exists in New Zealand allows commercially or centrally available resources to shape what Apple describes as the curriculum's "official knowledge." ${ }^{29}$ Apple has traced a trend which occurred in curriculum delivery within many OECD countries from the 1960s through which curricula were

\footnotetext{
${ }^{26}$ S. Meffin, personal interview, May 24, 2011.

${ }^{27}$ S. Meffin, personal interview, May 24, 2011; Peter Thomas, personal interview, May 27, 2011.

${ }^{28}$ P. Thomas, personal interview, May 27, 2011.

${ }^{29}$ M. Apple, Official Knowledge.
} 
purchased or centrally provided rather than created by teachers. In the United States, this initially gained momentum during the 'Sputnik era', in which the Government took tight control of the curriculum in order to promote economic and scientific development. ${ }^{30}$ In New Zealand, the complex nature of assessment task and schedule writing for high stakes standards-based internal assessment and inadequate levels of training led many teachers to opt for 'expert' generated tasks that were either commercially produced or downloaded from Ministry of Education or NZQA websites. In 2005, only thirteen per cent of Level Two History tasks submitted to NZQA moderators were written by teachers within the school which used them for assessment. ${ }^{31}$ Reflecting on the differences between Sixth Form Certificate and the NCEA on the development of a school-based History programme, Simon Dench observed that there was greater autonomy for teachers under Sixth Form Certificate when they "weren't told what good history was, [that] it had to fit into that box or you couldn't do it for assessment, or you can't assess it unless you do it in this particular way." ${ }^{32}$

During the unit standards trial period, a pre- and post-task moderation model operated, through which teachers were required to submit an assessment task they had written to a subject specialist moderator prior to its distribution to students and then send samples of student work at the end of the process. This provided an opportunity for teachers to discuss aspects of their curriculum and assessment programmes with a colleague and as a result improve their ability to write standards-based assessment tasks. While the NCEA also had an external moderation system, its effectiveness in helping develop teachers' assessment writing capacity was reduced as the moderation only occurred after the assessment had been administered and marked. The identity of the person moderating achievement standard work was also kept secret from the teacher, with a process established by which teachers submitted the work to their school's NZQA Principal's Nominee rather than sending it directly to the Moderator. An opportunity to develop professional connections between teachers through the moderation process appears to have been lost.

\footnotetext{
${ }^{30}$ M. Apple, "Curriculum Planning," 25-41.

${ }^{31}$ NZQA provided this data from the 117 schools who submitted Level Two History materials for moderation in 2005. On the moderation cover sheets, teachers were required to identify the source of the assessment task within four categories: "Own" (15 schools), "MOE/NZQA" (48 schools), "Commercial" (16 schools) and "Other" (38 schools).

${ }^{32}$ S. Dench, personal interview, May 27, 2011.
} 
Teachers in this study, who had been part of the unit standards trial community and benefitted from the professional development and pre-task moderation which accompanied it, found the transition to achievement standards internal assessment relatively smooth. Hamilton Girls' High School History Department's experience with the unit standards made the switch to achievement standards "very straight forward." ${ }^{33}$ Carol Jarman successfully adapted her unit standards task, which involved student speeches in the role of an historical figure, to meet the requirements of the new achievement standards. The students used 'flip' cameras to record the presentations, with the recordings used for moderation purposes. $^{34}$ Paul Wulff continued with the Central Otago field-trip which had begun several years earlier as part of the assessment programme for Sixth Form Certificate at Mountainview High School. The assessment task evolved to meet the requirements of the achievement standards, with students required to recreate a gold miner's diary, equipment and guide book in a manner which communicates historical ideas about life during the gold rushes. $^{35}$

With his expertise in standards-based assessment, developed during the unit standards era, Paul Wulff has found writing and reworking internally-assessed achievement standards tasks and making requisite adjustments to his teaching programme professionally satisfying:

It is immensely satisfying but more than that, to be able to keep perfecting them as you go along, making changes to them. You are not stuck in that world that we were in the 1970s and [19]80s where everything was very rigid and once you got a set of notes you would hardly bother changing them because year after year, you could use the same stuff. You can't do that anymore. You have to keep thinking about the issue of how your teaching is assisting students to meet the demands of the achievement standards... they are being assessed by. ${ }^{36}$

\footnotetext{
${ }^{33}$ C. Jarman, personal interview, May 26, 2011.

${ }^{34}$ C. Jarman, personal interview, May 26, 2011.

${ }^{35}$ P. Wulff, personal interview, June 29, 2011.

${ }^{36}$ P. Wulff, personal interview, June 29, 2011.
} 


\section{External Assessment - Essay questions}

The introduction of a standards-based approach for internal assessment represented a major shift for those not involved in the unit standards trial and a much smaller shift for those who had. However, the introduction of external standards-based assessment through the NCEA was a major development for all History teachers. The first NCEA Level Two History examination was held on the morning of Friday $21^{\text {st }}$ November, $2003 .{ }^{37}$ It was New Zealand's first national examination for Year 12 History since 1985. As there had been no significant curriculum changes for History since 1989, a situation now existed in which a curriculum designed to be internally assessed was now to be partially externally assessed.

NZQA contractors who were charged with the responsibility of writing the first examination faced the prospect of producing a paper which would fairly assess each of the thirty possible topics. Worse still, due to the nature of internal assessment, there were no mandated curriculum guidelines about what should be covered within each topic. The contractors' solution was to provide one generic question for each of the essay standards. Candidates would answer this question drawing on material from one of the topics that they had studied throughout the year. In a similar fashion, the source analysis achievement standard would be based on a setting not included in any of the thirty topics. It would assess skills and comprehension rather than historical understanding. Paul O'Connor remembers how the assessment practice within another subject area had an impact on the style of questions which would emerge for History:

There is no way an examiner could have written an exam that would have guaranteed that every kid in New Zealand could have attempted [the questions] when you had such a wide variety of topics, so the only way forward was generic questions. [Another contractor] and I did a lot of talking about this and he said, 'Look, if it's good enough for the English teachers to teach different texts and they don't have any difficulty, why should we?'... I thought he was right about that. This is a teaching issue not an assessment issue. It is a teacher's job to decode the exams

\footnotetext{
37 “Final Examination Timetable for 2003," May 15, 2003, SecQual S2003/044, NZQA Archives.
} 
for the students and put them in a position to be able to attempt the style of questions that are there. ${ }^{38}$

However, essay writing in English differs significantly from essay writing in a History examination. The focus of English examination essays is on the techniques which writers utilise to convey meaning to readers. ${ }^{39}$ English teachers explicitly teach those techniques and use texts to illustrate them. ${ }^{40}$ Disciplinary History first and foremost involves developing understanding of an historical context. To extract an understanding of concepts such as 'forces', 'movements' and 'identity' out of that context so that they can be at the forefront of an essay requires much more sophisticated thinking. Although there is a clear distinction between literary techniques and the literature, historical concepts and historical settings, especially at Year 12 level, are much more intricately intertwined.

The generic approach differed significantly from previous essay writing assessments. Although the internally assessed unit standards had 'decontextualised' standards, teachers would still provide a specific question on a topic which the students had studied as the basis for assessment. Under NCEA, students were essentially required to formulate the question for themselves. The 2004 examination essay questions are typical of those which have been used to assess the externally assessed standards for NCEA History since 2003. The essay topic used for assessing achievement standard 90469, an essay about the impact of an historical force or movement, drew on a list of 34 different 'forces' or 'movements' and required students to:

"Choose ONE historical force or movement from the list above, or from your own knowledge, that has played an important part in one of the topics you have studied this year. From this chosen topic, select an event that brought about important political change. In what ways did the background and outcomes of an event that

\footnotetext{
${ }^{38}$ P. O'Connor, personal interview, June 28, 2011.

${ }^{39}$ For example, in 2004, Level Two English candidates were asked to "Analyse techniques used to show changes in a main character or individual in a text you have studied and why these changes were important to the text as a whole." NZQA, 2004 Level 2 English Examination - Achievement Standard 90377.

${ }^{40}$ See advice to English teachers in: NZQA, 2007 Level 2 English Assessment Report - Achievement Standard 90377.
} 
brought about important political change show the influence of a selected historical force or movement?"${ }^{\prime 1}$

A similar format was used in 2004 for assessing achievement standard 90470, which focused on individual and group identity. The examination stated that in "history, there have been various ways in which an individual or group identity has been formed or developed". It then listed a series of potential influences such as 'attitudes', 'beliefs', 'culture', 'ethnicity', 'gender' and 'values'. Candidates were then asked:

"In what ways did a significant leader or personality have an influence upon the development of a distinctive sense of identity in one of the topics you have studied this year?"42

Through school-based assessment, teachers framed examination questions for their students, pointing them towards content and concepts from a specific topic which had been taught in class. The examples outlined here appear to indicate that the imposition of an external examination structure on an 'internally assessed' curriculum shifted that onus of responsibility onto the students, who now had to select appropriate content from their year's course to apply to a generic question. However, teachers in this study hold differing views on the merits of the generic approach. Burnside High School's Paul O'Connor emphasises that generic questions allow "kids to play to their strengths, rather than the examiner making the decision" about what the students have to write about. ${ }^{43}$ Logan Park High School's Paul Enright greatly values the autonomy which a generic approach gives to students and teachers. He expressed a strong preference for the Level Two generic questions over the content specific Level Three questions which force teachers to venture into every possible corner of the curriculum in case a question on an obscure area is asked. ${ }^{44}$ Auckland Girls' Grammar School's and Queen's High School's History teachers suggest that their students have coped well with the new question style. Teachers from

\footnotetext{
${ }^{41}$ NZQA, 2004 Level Two History Examination - Achievement Standard 90469, 3.

${ }^{42}$ NZQA, 2004 Level Two History Examination - Achievement Standard 90470, 3.

${ }^{43}$ P. O'Connor, personal interview, June 28, 2011.

${ }^{44}$ P. Enright, personal interview, June 30, 2011.
} 
these schools believe that criticism from their teaching colleagues about the question style has been unwarranted. ${ }^{45}$

Other teachers pointed out weaknesses with the generic questions. They suggest that less able students can find the process of 'unpacking' the generic question daunting. ${ }^{46}$ Bruce Taylor has found that many of his students at The Correspondence School have been put off by the 'hook' which accompanies the question. ${ }^{47}$ It appears as if examiners have been concerned that students will simply regurgitate a prepared answer, so in most years they have included a phrase within the topic question which defines the type of event which students can write about. For example, one of the 2004 questions focused on an event which brought about "important political change." ${ }^{48}$ Other teachers have observed that these hooks and the generic questions suit some topics much better than others. They point out that students can therefore be disadvantaged by the wording of the question and the topic choices made by their teachers in a particular year. ${ }^{49}$

Mountainview High School teacher, Paul Wulff was one teacher in the study who believed that the essay should be internally assessed. In response to a question about his views on the generic approach, he explained:

I hate it. I just absolutely loathe it. I think it drives teachers towards creating a model essay for students. I think there is so much abstract thinking involved in trying to unpack the question that students often just find it too difficult. I think our less able students find it so difficult and baffling to get their heads around and so they are very reliant on a model or exemplar that a teacher would put before them.

Hargreaves has shown that external examinations have a major impact on classroom pedagogy in the senior school ${ }^{50}$ and this appears to have been true of the generic essay questions. Three teachers in the study explained how the complex approach required to

\footnotetext{
${ }^{45}$ R. Webb, personal interview, June 30, 2011; Margaret Cotter, personal interview, May 25, 2011

${ }^{46}$ N. Hannan, personal interview, April 8, 2011.

${ }^{47}$ B. Taylor, personal interview, April 12, 2011

${ }^{48}$ NZQA, 2004 Level Two History Examination - Achievement Standard 90469, 3.

${ }^{49}$ S. Dench, personal interview, May 27, 2011; C. Jarman, personal interview, May 26, 2011.

${ }^{50}$ Hargreaves, Curriculum and Assessment Reform, , 61
} 
address the generic questions have forced them to be much more deliberate in the way in which they prepare students for their examination essays. Paul O'Connor's approach of using teacher-prepared exemplar essays to assist students in identifying the key features of an essay written in response to a generic style question is typical of other schools. He explained that the generic questions have forced him to be "much more hands-on and much more directive" ${ }^{\prime 1}$ than he was when he prepared students for internally assessed Sixth Form Certificate essays.

\section{External Assessment - Source Analysis}

The third achievement standard which became externally assessed from 2003 was achievement standard 90467 - Examine evidence in historical sources. Through the internally assessed unit standards, teachers were able to select documents from the topics they were studying in class and use these as the basis of the assessment of source analysis skills. With the new external achievement standards assessing a broad curriculum of thirty topics, NZQA contractors were also forced to 'decontextualise' the assessment. With the aim of creating a level playing field, they opted to choose documents from outside of the thirty topics which were available for study. The 2003 paper provided resources based on Scott's Antarctic exploration ${ }^{52}$ and the 2004 paper drew on historical resources from the American Civil War. ${ }^{53}$ A more recent paper focused on the death of Diana Princess of Wales! $!^{54}$ In Chapter Five we saw that a similar decontextualised approach had previously been taken for the source analysis section of the Sixth Form External Examination. However, unlike the independent exam, in which correct answers were added together to generate a percentage mark, the NCEA examination had to be constructed in such a way that each question demonstrated a specific skill as indicated by the criteria of the achievement standard. While it was possible to add up scores from correct answers to questions based on decontextualised sources to award the quantitative criteria, it was extremely difficult to adequately assess the qualitative criteria using the same type of sources. In particular, the 'excellence' criterion for 'explaining historical relationships', required students' answers to be 'informed'; but how could a student be 'informed' if they

\footnotetext{
${ }^{51}$ P. O'Connor, personal interview, June 28, 2011.

52 NZQA, Level Two History Examination 2003, Achievement Standard 90467.

${ }^{53}$ NZQA, Level Two History Examination 2004, Achievement Standard 90467.

${ }^{54}$ NZQA, Level Two History Examination 2007, Achievement Standard 90467.
} 
were unfamiliar with the context? Similarly, the achievement standard's 'excellence' criterion for 'describing the usefulness and/or reliability of evidence' required a 'perceptive' explanation. In the discipline of History, perception is gained through deep understanding of an historical context. Historians are able to make judgments about the reliability of evidence, by comparing it with other evidence that they have studied on the same topic. This was clearly not possible with decontextualised source material. The 2003 and 2004 assessment schedules indicate that the marking panel ignored the qualitative criteria of the standard and simply awarded the grades based on the number of correct answers. ${ }^{55}$ This appears to be an implicit acknowledgement that the requirements of the achievement standard could not be met within the confines of external examination based on decontextualised sources.

Many of the teachers in this study are uncomfortable with this decontextualised approach, suggesting that it is a non-historical exercise in comprehension, ${ }^{56}$ offering no challenge at all to literate students. ${ }^{57}$ Occasionally, students have fortuitously held some background knowledge on the topic. Their teachers believe this has been to their advantage. A Hillcrest High School student who migrated from Canada had studied a unit the American Civil War at his previous school. Peter Thomas remembers him being aided by his historical knowledge and gaining 'excellence' ${ }^{58}$ Students who had been watching the Days of Heaven movie may also have benefited from a more recent set of sources on the Crusades used for this achievement standard. ${ }^{59}$ Although Margaret Cotter has found the generic essay questions to be suitable for her students at Auckland Girls Grammar School, she has been dissatisfied with the decontextualised sources. She suggests that without an historical context which they have become familiar with in class, students from non-English speaking backgrounds struggle with the literacy requirements of the source material. Her experience is that such students perform better in the equivalent assessment in Level Three because

\footnotetext{
${ }^{55}$ NZQA, 2003 Level 2 History Assessment Report - Achievement Standard 90467; NZQA, 2004 Level 2 History Assessment Report - Achievement Standard 90467.

${ }^{56}$ e.g. S. Dench, personal interview, May 27, 2011.

${ }^{57}$ B. Taylor, personal interview, April 12, 2011

58 P. Thomas, personal interview, May 27, 2011.

${ }^{59}$ P. Enright, personal interview, June 30, 2011.
} 
the source material is specific to a topic they have studied, even though the questions are set at a higher level. ${ }^{60}$

\section{Curriculum Choices}

Although the changes to Year 12 History from 2003 focused on assessment rather than curriculum, NCEA has brought about changes to the content of what has been taught at this level in most of the schools in this study. The introduction of external assessment has, in the experience of Paul Enright, made the programme at Logan Park High School more content focused, particularly in comparison to the unit standards period, where the focus was more explicitly on understanding historical concepts and ideas. ${ }^{61}$

While few teachers changed topics when new options became available with the introduction of the new curriculum in 1989, NCEA has brought about change. Teachers in this study were prepared to switch to new topics if they believed that they would better prepare students for the external essay writing achievement standards. Carol Jarman's experience has been that that several of the established topics do not provide material which is easily transferred to the essay questions. The regular political focus of the questions has encouraged her to continue teaching the 'Russia Revolution' every year at Hamilton Girls' High School, while she has rotated the other topics in her programme. ${ }^{62}$ At Palmerston North Boys' High School, 'The Origins of World War One' topic was discarded on the basis that it did not provide useful material for the examination standards. Dominic King's programme now consisted of topics on 'Gandhi and Indian Nationalism', 'The Vietnam War' and 'Nazi Germany'. These topics were selected as they each provided opportunities for students to answer both essay questions. ${ }^{63}$ At Mountainview High School, Paul Wulff started teaching the Gandhi topic in the NCEA era. He discovered that this allowed students to 'double-dip' in the examination, with the Satyagraha campaign an example of an historical movement for one essay and the focus of group identity in the

\footnotetext{
${ }^{60}$ M. Cotter, personal interview, May 25, 2011. (As there are only two topic options for Year 13 History, the examination provides source material from within the context which the students have studied.)

${ }^{61}$ P. Enright, personal interview, June 30, 2011.

${ }^{62}$ C. Jarman, personal interview, May 26, 2011.

${ }^{63}$ D. King, personal interview, April 12, 2011.
} 
other. ${ }^{64}$ Similar decisions were made at Howick College, with 'Nazi Germany' and the 'Russian Revolution' promoted (at the expense of 'The Growth of New Zealand Identity') as they "fitted perfectly into 'force and movement' and 'identity.'" 65

The essay writing achievement standards also appear to have completely divorced the topics from their prescribed themes. Dominic King's experience at Palmerston North Boys' High School is typical of many teachers in the study, who acknowledged that the conceptual focus of the essays i.e. 'forces', 'movements' and 'group and individual identity', have become the de-facto themes for the course. ${ }^{66}$ Teachers appear to no longer make connections to the official themes outlined in the Prescription, but they regularly identify potential 'forces', 'movements', 'individuals' and 'groups' which could inform student essay writing, as a key component of their teaching. ${ }^{67}$

While the Sixth Form Certificate Prescription mandated that four different topics were to be taught through the course of the year (plus research work), the NCEA has led to this number being reduced in most of the schools in this study. Teachers at Palmerston North Boys' High $^{68}$ School, Hillcrest High School ${ }^{69}$, Auckland Girls' Grammar School ${ }^{70}$, Mountainview High School $^{71}$ and Hutt Valley High School ${ }^{72}$ now teach three topics to their Year 12 History students. At Howick College, just two major topics are covered; ${ }^{73}$ while at the Correspondence School (Te Kura), it is common for students to study either one or two topics. $^{74}$ The decontextualised standards seem to have led to a concentration on depth at the expense of breadth. Teacher participants in this study had differing views on the merits of this change. While depth allows for an increased understanding of disciplinary History, studying fewer topics reduces the opportunity for students to be exposed to a range of ideas and concepts from different settings.

\footnotetext{
${ }^{64}$ P. Wulff, personal interview, June 29, 2011.

${ }^{65}$ S. Meffin, personal interview, May 24, 2011.

${ }^{66}$ D. King, personal interview, April 12, 2011.

${ }^{67}$ D. King, personal interview, April 12, 2011.

${ }^{68}$ D. King, personal interview, April 12, 2011.

${ }^{69} \mathrm{P}$. Thomas, personal interview, May 27, 2011.

${ }^{70}$ M. Cotter, personal interview, May 25, 2011.

${ }^{71} \mathrm{P}$. Wulff, personal interview, June 29, 2011.

${ }^{72}$ N. Hannan, personal interview, April 8, 2011.

${ }^{73} \mathrm{~S}$. Meffin, personal interview, May 24, 2011.

${ }^{74}$ B. Taylor, personal interview, April 12, 2011
} 
It has also become common for school programmes to bypass one or more of the achievement standards which are available for assessment. For example, statistics on NZQA examination entries indicate that some schools choose to enter their students for just one of the external essay standards. ${ }^{75}$ It is also apparent that students make pragmatic decisions, sometimes not attempting one or more of the achievement standards which their school has entered them in. ${ }^{76}$ Under the Sixth Form Certificate, where all assessment marks contributed to the end-of-year grade, the penalty for such decisions was much more severe.

On reflection, Dominic King believes that the concerns which he and other critics expressed about the compartmentalisation of History through the division of the discipline up into separate units, have not materialised. ${ }^{77}$ It seems that the decision of the standards writers to focus on skills and concepts instead of content, has allowed teachers to continue to teach a series of topics, making connections between them and building skills and understanding as the course develops. This differs from the experience of teachers and students in some other subject areas, where the achievement standard provides a summative assessment for each teaching unit. This latter approach can result in students 'putting the lid' on the content and skills from the assessed unit rather than using them as building blocks for the overall understanding which underpins a disciplinary course. ${ }^{78}$

\footnotetext{
${ }^{75}$ Data provided by NZQA shows that in 2005, 6008 students were entered into achievement standard 90467 (source analysis), 5910 students were entered in 90469 (force/movement essay) and 5415 in 90470 (identity essay). This trend of schools entering students in some rather than all the external achievement standards has been more pronounced in recent years. For example in 2010, 6476 students were entered in AS90467; 5998 in AS90469, and just 5171 in AS90470.

${ }^{76}$ Data provided by NZQA shows that in 2005, 27 per cent of students entered into AS90470 chose not to attempt the essay question during the examination. For AS90469, 16 per cent did not attempt the essay question. For both standards 9 per cent failed to attend the examination. This trend has continued. In 2010, 29 per cent chose not to attempt AS90470; with 24 per cent choosing not to attempt AS90469. A further 6 per cent of those entered failed to attend the examination.

77 D. King, personal interview, April 12, 2011

${ }^{78}$ For example, the Level Two Geography achievement standards are derived from teaching units rather than overall concepts, with a different standard used to assess each content area. NZQA, AS90331 explicitly assesses student understanding of natural processes which shaped the landscape. This would be taught in a stand-alone unit. This differs from the approach in History, where the standards focused on skills and concepts covered in all units.
} 


\section{The End of the Local Courses}

In Chapter Four we saw that several of the schools in this study had taken up the opportunity which Sixth Form Certificate provided to develop 'local courses'. Despite the Qualification Authority's insistence that "schools can run the same courses that they run now"79 few local courses survived the transition to NCEA. The popular International Relations course at Hutt Valley High School lasted until 2003. The course had largely been based on history methodology, with an emphasis on the past informing the present. Under NCEA, just one set of History achievement standards was available. The standards closely tied the content of the curriculum to the assessment. In this new qualifications environment, Hutt Valley High School teachers decided that it was no longer possible to offer two distinct courses. Some of the material from the local course was moved into the Year 12 History programme, but teacher Noeline Hannan suggests that the level of student interest and engagement in the International Relations course has not been replicated. ${ }^{80}$ Burnside High School's local course, which focused on social history and emphasised the development of student research skills, also ended with the introduction of NCEA. Paul O'Connor believed that the new system provided possibilities within the conventional Year 12 History course to further the emphasis on social history. Consequently the separate Social History course ended, with local and 'hands-on' history becoming the major foci of the internally assessed components of Burnside High School's Level Two programme. ${ }^{81}$

\section{Alternative Examinations}

Although the NCEA was a political compromise which brought back graded and external assessment to the National Qualifications Framework in order to appease its opponents, several principals of 'elite' schools retained major reservations about the form of standardbased assessment which it introduced. We have seen that independent examinations were introduced as an alternative to internal assessment in some of these schools. In Chapter Three, we noted the arrival of the Cambridge International Examinations (CIE) to New Zealand in 2002 as a response to dissatisfaction with the National Certificate of Educational Achievement. From 2003, the CIE programme offered a range of examinations for Year 12

\footnotetext{
79 "The Facts about NCEA," NCEA Update, August 2, 2000, NZQA Archives.

${ }^{80}$ N. Hannan, personal interview, April 8, 2011.

${ }^{81}$ P. O'Connor, personal interview, June 28, 2011.
} 
and 13 History programmes in New Zealand of which 'International History 1945-1991', 'Modern European History 1789-1939', and 'The History of the USA c.1840-1968' were the most popular. ${ }^{82}$ The format of each examination is the same. It includes a source analysis component (worth 25 marks) in which the students are given four or five written sources, drawn from the historical setting they have studied, and asked to respond to a hypothesis, drawing on material from the sources and their own knowledge. The students then select three essay topics (each worth 25 marks) from a list of eight possible options. The essay questions have an explicit content focus. For example, students who sat the 'Modern European History 1789-1939" paper in 2006 were asked "How stable was the Tsarist regime in Russia on the eve of the First World War in 1914?"83 The way in which these examinations allow students to analyse sources and show their understanding of historical content within the topics they have been studying provides a better alignment with the discipline of History than the decontextualised external assessment for Level Two NCEA. However, by completely closing the door on internal assessment, schools which opt for these examinations instead of the NCEA are denying their students the opportunity to develop the disciplinary thinking which is associated with framing an historical inquiry, gathering and selecting historical evidence and presenting ideas which their research has generated.

\section{Conclusion}

This chapter shows that the complex nature of NCEA assessment and inadequate levels of training for teachers in task writing led to a de-facto curriculum emerging in some schools. This involved some Year 12 History teachers purchasing or downloading internal assessment tasks and then building a programme around them. Other teachers, who developed assessment expertise in the unit standards trial, in which a participatory model of professional development operated, have more successfully adapted their school-based History programmes to meet the needs of their students and the achievement standards. It has been argued that the impact of the imposition of external assessment on a broad Year 12 curriculum, which was designed with the intention that it would be fully internally assessed, has been negative. The historical emphasis of the two generic essay writing

\footnotetext{
82 J. Manning (CIE Administrator), Personal Communication, October 27, 2011.

${ }^{83}$ CIE AS Modern European History 1798-1939 Examination, May/June 2006, 4.
} 
achievement standards has altered both the content and pedagogy of Year 12 History courses, in some cases in a manner not justified by the content of the curriculum documentation. Although teachers are divided on the merits of the generic approach to examination setting which external assessment has forced on Year 12 History, this chapter has argued that it has led to a disconnection between disciplinary history and its assessment for qualifications. The evidence suggests that Year 12 History programme have been caught in-between competing curriculum and assessment philosophies. 


\section{Chapter Eight}

\section{Conclusion}

"Extended professionals... are skilled classroom teachers and more besides. They know about the broader context in which they work, and the wider issues in education and society; they continue their professional education, read professional literature, visit other schools, collaborate with colleagues and get involved in policy development and professional associations; and they sometimes undertake research." ${ }^{1}$

Clive McGee

This case study has examined tensions between the development of a high teacher autonomy curriculum for Year 12 History and different forms of mandated national assessment between 1986 and 2005. Teachers' decisions during this period were made within the context of a rapidly changing educational environment. Year 12 History's broad discipline-based syllabus was developed at the end of the Department of Education era, delivered to schools during the Tomorrow's Schools reforms and eventually assessed, both internally and externally, in the era of standards-based assessment for qualifications. It was therefore 'caught in between' the changes to the educational bureaucracy and national qualifications.

In theorising Year 12 History in relation to the thinking and framework of its parent discipline, this thesis suggests that within this changing context, teachers' own backgrounds in disciplinary History influenced the decisions which they made on behalf of their students. While their 'historical thinking' led them to embrace student-centred research tasks, made possible through internal assessment, it may also have prevented some teachers from selecting topics which challenged traditional disciplinary approaches with feminist or indigenous perspectives.

This thesis has shown that in a high autonomy environment, assessment considerations dominate teachers' decisions concerning curriculum and pedagogy. When the fully

\footnotetext{
${ }^{1}$ McGee, Teachers and Curriculum Decision-Making, 29.
} 
internally assessed Sixth Form Certificate was introduced from 1986, most teachers in this study adopted new teaching approaches or explored new content areas within their existing topics. In contrast, the introduction of new curriculum documentation from 1989 had minimal impact on classroom practice. While there was little movement between the curriculum's topics within schools in the internal assessment era, the introduction of external assessment in 2003 led several teachers in this study to switch, in order to ensure that their students were well placed for success in the essay achievement standards. The extent to which assessment trumps curriculum in the senior secondary school underlines the importance of curriculum and assessment for qualifications being developed in tandem. This was not a feature of the development of standards-based assessment for History and as a result tensions emerged between the philosophy of a broad discipline-based syllabus and the rigid approach of standards-based assessment which was selected for New Zealand qualifications. Instead of one-size-fits-all model, an ideal qualifications system would provide the flexibility for each subject discipline to adopt the mode and style of assessment which best aligned with its curriculum.

The New Zealand Curriculum now provides even greater autonomy for teachers of Year 12 History than existed in the period in which this study is set. Starting in 2012 teachers are free to select any historical settings or topics for their students to study, without restriction. Like Sixth Form Certificate, the aim of this development is to provide opportunities for teachers to cultivate a school-based curriculum. Unlike teachers of Sixth Form Certificate History, today's teachers must work within the confines of a standards-based assessment environment, where internal assessment task writing is a specialist act and the external assessment's generic questions distance the discipline from its assessment. It will be the task of future researchers to explore teacher decision-making within this environment, but the experience of the past suggests that teachers are generally reluctant to engage with new content or approaches, unless they have personal interest or expertise in the proposed area of study. The availability of suitable resources for classroom use is another factor in their curriculum decision-making which has the potential to hinder the development of a school-based History curriculum. 
It could be argued that an increased level of autonomy for teachers over curriculum needs to be accompanied by greater professional responsibility. More than ever, teachers are required to be what Hoyle and McGee term 'extended professionals'. Such teachers understand the social and educational context in which they operate, collaborate with teachers in other schools and critique their practice in relation to research into the teaching of their discipline. ${ }^{2}$ There were several teachers in this study who displayed these attributes, but the development of a profession along these lines, presents a challenge to policy makers, teacher educators and school leaders. Assisting teachers in navigating the tensions between their curriculum which encourages teacher autonomy, and its national assessment which reduces it, will be an important first step.

\footnotetext{
${ }^{2}$ McGee, Teachers and Curriculum Decision-Making.
} 


\section{Appendix 1}

\section{Teacher Interview Questions}

1. In which New Zealand schools have you taught? What can you tell me about these schools? When were you working at each of these schools?

2. What involvement did you have with regional or national history teachers' associations during this time?

3. Thinking back to the days before Sixth Form Certificate stood alone as a qualification, can you remember what topics you covered in your school's Sixth Form History programme? How did the Sixth Form Programme fit in with the content which was covered at other levels?

4. Can you describe the teaching and learning which took place in Sixth Form History during the University Entrance era? What was a typical lesson like? Was there any scope for students to carry out autonomous research tasks? Were there any field trips? In what form?

5. The accreditation of University Entrance was one of the first steps towards internal assessment in education in New Zealand. How did this process operate in your school? What impact did it have on teaching and learning in your Sixth Form history classes?

6. From 1986, Sixth Form Certificate became a stand-alone qualification and the University Entrance qualification was abolished. What impact did a fully internally assessed course have on your teaching and on the students' learning? What did you teach? How did you teach it? What opportunities did students have for autonomous learning within the Sixth Form Certificate programmes that you taught?

7. In 1989 a new prescription for Sixth Form Certificate History was gazetted. It offered a range of new topics and the continuation of some of the previous UE topics. Which of these topics did you teach? How did you make the choices about which topics to teach? What tasks did you use to assess the students?

8. In the late 1980s and 1990s, major reforms were taking place in New Zealand education, such as the Tomorrow's Schools reforms and the gradual introduction of an outcomes-based curriculum? What impact did these reforms have on your school? What impact did they have on your history teaching and student learning of history? Specifically, could you comment on the introduction of the 1997, Social Studies in the New Zealand Curriculum (which included achievement objectives for Years 1-13 Social Studies) in your school? What impact, if any, did this document and its style have on your Sixth Form Certificate History programme?

9. Between 1996 and 2002, unit standards were available for assessment in history in Years 11-13. Did your department use any of these unit standards for assessment? 
Why? Why not? What impact did these unit standards have on the teaching and learning which took place in your Sixth Form programme?

10. The NCEA was introduced in 2002 and the Level 2 NCEA qualification was first offered to students in 2003. How did the reintroduction of externally set and marked examinations have an impact on your Year 12 History programme? Did you change the topics that you taught? How did you make those decisions? What impact did new styles of assessment, both internal and external, have on the teaching and learning in your Year 12 History programme. 
Appendix 2

Purposive Sampling Matrix

\begin{tabular}{|c|c|c|c|c|c|c|c|c|c|c|}
\hline $\begin{array}{c}\text { Teacher } \\
\text { Participant }\end{array}$ & $\begin{array}{c}\text { Main School 1986- } \\
2005\end{array}$ & $\begin{array}{l}\text { Current } \\
\text { Decile }\end{array}$ & $\begin{array}{c}\text { Single- } \\
\text { Sex }\end{array}$ & Co-ed & Provincial & Urban & $\begin{array}{l}\text { Large } \\
(1000+)\end{array}$ & $\begin{array}{c}\text { Small } \\
(<1000)\end{array}$ & Male & Female \\
\hline Noeline Hannan & $\begin{array}{l}\text { Hutt Valley High } \\
\text { School }\end{array}$ & 8 & & $X$ & & $X$ & $X$ & & & $X$ \\
\hline Bruce Taylor & Tararua College & 4 & & $X$ & $X$ & & & $\mathbf{x}$ & $X$ & \\
\hline Dominic King & $\begin{array}{l}\text { Palmerston North } \\
\text { Boys' High School }\end{array}$ & 9 & $\mathbf{x}$ & & $x$ & & 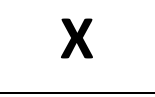 & & $X$ & \\
\hline Sheryll Ofner & Selwyn College & 4 & & $\mathbf{x}$ & & $\mathbf{x}$ & & $\mathbf{x}$ & & $\mathbf{x}$ \\
\hline Sharyn Meffin & Howick College & 10 & & $\mathbf{x}$ & & $\mathbf{X}$ & $\mathbf{x}$ & & & $\mathbf{x}$ \\
\hline Margaret Cotter & $\begin{array}{l}\text { Auckland Girls' } \\
\text { Grammar School }\end{array}$ & 5 & $\mathbf{X}$ & & & $X$ & $\mathbf{X}$ & & & $x$ \\
\hline Carol Jarman & $\begin{array}{l}\text { Hamilton Girls' } \\
\text { High School }\end{array}$ & 6 & $X$ & & & $X$ & $X$ & & & $X$ \\
\hline $\begin{array}{l}\text { Peter Thomas } \\
\text { and Simon Dench }\end{array}$ & $\begin{array}{l}\text { Hillcrest High } \\
\text { School }\end{array}$ & 8 & & $X$ & & $X$ & $X$ & & $X$ & \\
\hline Paul O'Connor & $\begin{array}{l}\text { BurnsIde High } \\
\text { School }\end{array}$ & 8 & & $X$ & & $x$ & $X$ & & $X$ & \\
\hline Paul Wulff & $\begin{array}{l}\text { Mountainview High } \\
\text { School }\end{array}$ & 6 & & $X$ & $X$ & & & $\mathbf{x}$ & $X$ & \\
\hline Richard Webb & $\begin{array}{l}\text { Queen's High } \\
\text { School }\end{array}$ & 5 & $x$ & & & $x$ & & $x$ & $x$ & \\
\hline Paul Enright & $\begin{array}{l}\text { Logan Park High } \\
\text { School }\end{array}$ & 7 & & $x$ & & $X$ & & $\mathbf{x}$ & $x$ & \\
\hline
\end{tabular}




\section{Appendix 3}

\section{Ethics Approval}

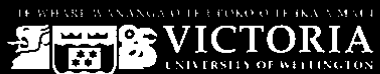

FACULTY OF EDUCATION TE WHÃNAU O AKO PAI

DONALD STREET PO BoX 17310 , Karori 6147, Wellington, New Zealand

Phone +64-4-4639500 Fax +64-4-4639649 Website www.vuw.ac.nz/education

6 September 2010

\section{Gregor Fountain}

MEd Student

Victoria University of Wellington Faculty of Education

$\mathrm{C} /$ - School of Education Policy and Implementation

Donald Street

Wellington

\section{Dear Gregor}

\section{RE: Ethics application SEPI/2010/74: RM 17944}

I am pleased to advise you that your ethics application 'Caught In-Between: The Impact of Standards-Based Assessment on a Discipline-Based, Senior Academic Subject: Year Twelve History in New Zealand 1989-2005', with the requested amendments, has been approved by the Victoria University of Wellington Faculty of Education Ethics Committee. Please note that the approval for your research to commence is from the date of this letter.

Best wishes for your research.

Yours Sincerely

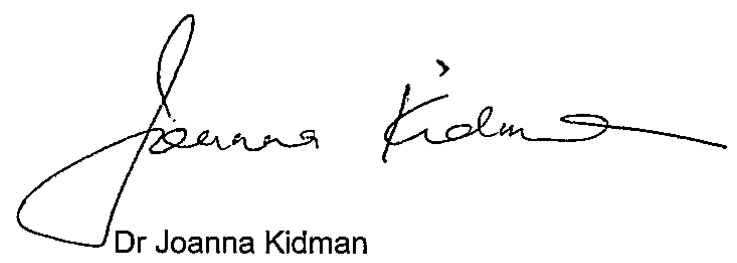

Co-Convenor

Victoria University of Wellington Faculty of Education Ethics Committee 


\title{
Appendix 4
}

\section{Introductory Letter}

\author{
Gregor Fountain \\ Wellington College \\ PO Box 16073 \\ WELLINGTON \\ g.fountain@wellington-college.school.nz \\ 04-8022565 and 021-2010446
}

Date

\section{"Caught In-Between" - Information for Participants}

Dear

I am currently researching a Masters of Education thesis (Victoria University of Wellington School of Educational Policy and Implementation) which investigates the impact of internal assessment on Year 12 History between 1986 and 2005 and examines how history teachers operated in the high autonomy environment which characterised teaching programmes at this level. It is hoped that this study will provide insights into the implementation of the 2007 New Zealand Curriculum. My supervisor is Dr Mark Sheehan (Senior Lecturer, Victoria University of Wellington School of Educational Policy and Implementation).

This research has been assessed and approved by Victoria University of Wellington Faculty of Education Ethics Committee (Reference: 17944).

The sources of information for this qualitative study include archival material held at the New Zealand Qualifications Authority and Archives New Zealand and a series of semistructured interviews with education officials and teachers who were involved in history education between 1986 and 2005.

I would be most grateful if you would be prepared for me to interview you. My intention would be to record the interview digitally and use information from the interview in my thesis. I would expect the interview to last a maximum of 90 minutes. A series of interview questions which may be used is attached.

After the interview, I will make a selection of quotations from the interview which may inform aspects of my thesis. These will be made available for you to check and for three months after the interview you will have the opportunity to amend and delete any comments in the transcript so that you are satisfied that it is a true and accurate record of 
what you have said. If you wish to completely withdraw your interview data, you can do so at any time until $1^{\text {st }}$ September 2011.

As is common in historical research which draws on oral sources, it is my intention if I choose to quote you directly, that you will be named in my thesis. Any direct excerpts which I intend to use will be sent to you for approval prior to their use.

The information (both digital recording and written material) will be stored in a secure site and only my supervisor and I will have access to this stored information. All data will be destroyed three years after the completion of the research project.

If you require clarification on any aspect of this research, please contact me or Mark Sheehan. We are both willing to answer any questions that you might have.

Participation in the research is entirely voluntary. If you are prepared to take part, please email or phone me so that we can make arrangements for the interview to take place.

Yours faithfully

Gregor Fountain

Supervisor's contact details:

Dr Mark Sheehan

Senior Lecturer

School of Educational Policy and Implementation

Victoria University of Wellington

PO Box 600

Wellington 6140

NEW ZEALAND

mark.sheehan@vuw.ac.nz

04-4639687 


\section{Appendix 5 \\ Interview Consent Form}

\section{"Caught in-between" Interview Informed Consent}

This research has been assessed and approved by Victoria University of Wellington Faculty of Education Ethics Committee (Reference: 17944)

$\square \quad$ I give informed consent for Gregor Fountain, Masters student in Victoria University of Wellington's School of Education Policy and Implementation, to use the written and oral information provided in this interview for his thesis about Year 12 History between 1986 and 2005 and in any future articles and presentations which might be derived from this body of work.

$\square \quad$ I have been given and have understood an explanation of this research project. I have had an opportunity to ask questions and had them answered to my satisfaction.

$\square \quad$ I understand that I will also have the opportunity to view a transcript of quotations from the interview that will be selected as being potentially useful for the research and that for three months after the interview, I will be able to make amendments or deletions to these quotations as I see fit.

$\square \quad$ I understand that the information (both the digital recording and any written material) from this interview will be stored in a secure site at Wellington College and that all data will be destroyed three years after the completion of the research project.

$\square \quad$ I understand that my participation in this research project is completely voluntary and that I may withdraw my data from the project at any time until $1^{\text {st }}$ September 2011.

$\square \quad$ Please provide me with a summary of the findings of this thesis at the conclusion of the research project.

Participant:

Gregor Fountain:

Date: 


\section{Appendix 6}

\section{Transcript Release Form}

\section{"Caught in-between" - Transcript Approval}

$\square \quad$ I have had the opportunity to view quotations from the interview which have been selected as being potentially useful to informing the thesis.

$\square \quad$ I have made the necessary amendments and deletions.

$\square \quad$ I confirm that the selected quotations (including amendments and deletions) are accurate quotations from the interview.

Participant:

Date: 


\section{Appendix 7}

\section{Final Approval of Selected Quotations}

\section{"Caught in-between" - Approval of Selected Quotations}

$\square \quad$ I have had the opportunity to view the excerpts from the interview which have been selected for quotation in the final thesis

$\square \quad$ I have made the necessary amendments and deletions.

$\square \quad$ I confirm that the selected quotations (including amendments and deletions) are accurate quotations from the interview.

Participant:

Date: 
Bibliography

Interviews

\begin{tabular}{|l|l|l|}
\hline Interviewee & Date & Location \\
\hline Laurie Lord & March 30, 2011 & Wellington College \\
\hline David Wood & April 8, 2011 & Wellington College \\
\hline Noeline Hannan & April 8, 2011 & Hutt Valley High School \\
\hline Bruce Taylor & April 12, 2011 & Interviewee's home, Palmerston North \\
\hline Dominic King & April 12, 2011 & Palmerston North Boys' High School \\
\hline Sheryll Ofner & May 24, 2011 & Selwyn College \\
\hline Sharyn Meffin & May 24, 2011 & Howick College \\
\hline Margaret Cotter & May 25, 2011 & Auckland Girls' Grammar School \\
\hline Carol Jarman & May 26, 2011 & Hamilton Girls' High School \\
\hline Peter Thomas and Simon Dench & May 27, 2011 & Hillcrest High School \\
\hline Paul O'Connor & June 28, 2011 & Burnside High School \\
\hline Paul Wulff & June 29, 2011 & Mountainview High School \\
\hline Richard Webb & June 30, 2011 & Interviewee's home, Dunedin \\
\hline Paul Enright & June 30, 2011 & Logan Park High School \\
\hline
\end{tabular}

Archives New Zealand Files

\begin{tabular}{|l|l|l|}
\hline File & Title and Dates & Archives Reference \# \\
\hline R7 246543 & $\begin{array}{l}\text { Examinations - Sixth Form Certificate - Policy } \\
1982-1986 .\end{array}$ & ABEP W4262 77503576 \\
\hline R7 246544 & $\begin{array}{l}\text { Examinations - Sixth Form Certificate - Policy } \\
1985-1986 .\end{array}$ & ABEP W4262 77503576 \\
\hline R7 246558 & $\begin{array}{l}\text { Examinations - Sixth Form Certificate - } \\
\text { Miscellaneous Correspondence, 1983-1986. }\end{array}$ & ABEP W4262 7750 3578 \\
\hline R7 246569 & $\begin{array}{l}\text { Examinations - Sixth Form Certificate - } \\
\text { Assessment/Moderation - 1986. }\end{array}$ & ABEP W4262 77503579 \\
\hline R7 246574 & $\begin{array}{l}\text { Examinations - Sixth Form Certificate Assessment } \\
\text { Procedures - 1987-1990. }\end{array}$ & ABEP W4262 77503580 \\
\hline R 7 246585 & $\begin{array}{l}\text { Examinations - Sixth Form Certificate - Course } \\
\text { Approvals - 1987-1990 }\end{array}$ & ABEP W4262 7750 3581 \\
\hline R7 249 865 & $\begin{array}{l}\text { Staff and Salaries - Administration - Staff - Staff } \\
\text { Exchanges - Education Board and Department }\end{array}$ & ABEP W4262 7750 3854 \\
\hline R20 474 774 & $\begin{array}{l}\text { School Certificate Examination Board - } \\
\text { Miscellaneous - Sixth Form Certificate - Liaison } \\
\text { Committee - 1986. }\end{array}$ & AAZYP W3901 594 \\
\hline
\end{tabular}

\section{Personal Papers}

\section{Document}

Education Advisory Service, Auckland. Achievement Based Assessment in Collection

History. Auckland: Auckland College of Education, 1994. 


\begin{tabular}{|c|c|}
\hline Cleary, M. to C. Davis, May 27, 1985. & P. Lineham \\
\hline $\begin{array}{l}\text { Davis, C., "Summary of Preliminary Discussion of NHCC Newsletter } 6 \text { at } \\
\text { Seventh Form History Seminar, Massey University - August } 10^{\text {th }} 1984 . "\end{array}$ & P. Lineham \\
\hline Combined Schools. 1988 Sixth Form External Examination - History. & D. King \\
\hline Combined Schools. 2002 Sixth Form External Examination - History. & D. King \\
\hline “History Syllabus Committee Forms 5-7 Terms of Reference.” & P. Lineham \\
\hline Howe, K. to C. Davis, April 2, 1985. & P. Lineham \\
\hline “Manawatu History Society Resolutions - 30 th May 1984." & P. Lineham \\
\hline $\begin{array}{l}\text { “Matters Arising - National History Curriculum Committee Meeting, } \\
\text { Wellington, July 10-12 1987." }\end{array}$ & P. Lineham \\
\hline $\begin{array}{l}\text { "Minutes from National History Curriculum Committee, July } 29^{\text {th }}-2^{\text {nd }} \text { August, } \\
\text { 1985." }\end{array}$ & P. Lineham \\
\hline Poff, B. to C. Davis, April $16^{\text {th }}, 1985$. & P. Lineham \\
\hline $\begin{array}{l}\text { "Report from Wanganui History Teachers Meeting (9 Teachers) - } 13 \text { June } \\
\text { 1984." }\end{array}$ & P. Lineham \\
\hline $\begin{array}{l}\text { "Report of the Working Group on 'Women's Issues' in the Revision of the } \\
\text { Forms 5-7 History Syllabus - Thursday } 28 \text { February- Friday } 1 \text { March, 1985." }\end{array}$ & P. Lineham \\
\hline Sinclair, K. "Draft Outline - The Growth of New Zealand National Identity." & P. Lineham \\
\hline $\begin{array}{l}\text { Tarling, N. "Feedback from the Auckland History Teachers' Association - } \\
\text { September } 26^{\text {th }}, 1984 . "\end{array}$ & P. Lineham \\
\hline Teacher Survey Comments. [undated] & P. Lineham \\
\hline
\end{tabular}

\section{New Zealand Qualifications Authority Archives}

"Clarification of the Format and Topics Being Assessed in Level 1 and Level 2 History Examinations 2003." SecQual S2003/083. October 4, 2003.

"Evaluation of Internally Assessed Components of University Entrance, Bursaries and Scholarship Subjects - History." NZQA Circular CQ97/38S. 1997.

"The Facts about NCEA." NCEA Update. August 2, 2000.

“Final Examination Timetable for 2003." SecQual S2003/044. May 15, 2003.

"The National Qualifications Framework and the Record of Learning." Student Information Brochure, 1993.

"Sixth Form Certificate Grades Allocation." QA Operations Circular CQ96/19S. March, 22 1996.

\section{Unit Standards, Achievement Standards and Examination Papers}

New Zealand Qualifications Authority, 2003 Level 2 History Assessment Report Achievement Standard 90467. [Provided by NZQA. Not available online.] 
New Zealand Qualifications Authority. 2003 Level Two History Examination - Achievement Standard 90467 [Provided by NZQA. Not available online.]

New Zealand Qualifications Authority, 2004 Level 2 History Assessment Report Achievement Standard 90467. [Provided by NZQA. Not available online.]

New Zealand Qualifications Authority. 2004 Level Two English Examination - Achievement Standard 90377. Accessed November 12, 2011, http://www.nzqa.govt.nz/nqfdocs/ncea-resource/exams/2004/90377-exm-04.pdf.

New Zealand Qualifications Authority, 2004 Level Two History Examination - Achievement Standard 90467. Accessed December 5, 2011. http://www.nzqa.govt.nz/nqfdocs/ncea-resource/exams/2004/90467-res-04.pdf

New Zealand Qualifications Authority. 2004 Level Two History Examination - Achievement Standard 90469. Accessed December 5, 2011.

http://www.nzqa.govt.nz/nqfdocs/ncea-resource/exams/2004/90469-exm-04.pdf

New Zealand Qualifications Authority. 2004 Level Two History Examination - Achievement Standard 90470. Accessed December 5, 2011.

http://www.nzqa.govt.nz/nqfdocs/ncea-resource/exams/2004/90470-exm-04.pdf

New Zealand Qualifications Authority, 2007 Level Two History Examination - Achievement Standard 90467. Accessed December 5, 2011.

http://www.nzqa.govt.nz/nqfdocs/ncea-resource/exams/2007/90467-res-07.pdf

New Zealand Qualifications Authority. 2007 Level 2 English Assessment Report Achievement Standard 90377. Accessed November 12, 2011. http://www.nzqa.govt.nz/nqfdocs/ncea-resource/reports/2007/level2/english.pdf.

New Zealand Qualification Authority. Achievement Standard 90331 - Explain Natural Landscapes (Version 1). Accessed December 5, 2011. http://www.nzqa.govt.nz/nqfdocs/ncea-resource/achievements/2004/as90331.pdf.

New Zealand Qualification Authority. Achievement Standard 90466 - Communicate Historical Ideas To Demonstrate an Understanding of an Historical Context (Version 1). Accessed December 5, 2011. http://www.nzqa.govt.nz/nqfdocs/ncearesource/achievements/2005/as90466.pdf. 
New Zealand Qualification Authority. Achievement Standard 90467 - Examine Evidence in Historical Sources (Version 1). Accessed December 5, 2011.

http://www.nzqa.govt.nz/nqfdocs/ncea-resource/achievements/2004/as90467.pdf.

New Zealand Qualification Authority. Achievement Standard 90469 - Examine a Force or Movement that Influenced People's Lives in an Historical Setting, in an Essay (Version 1). Accessed December 5, 2011. http://www.nzqa.govt.nz/nqfdocs/ncearesource/achievements/2004/as90469.pdf.

New Zealand Qualification Authority. Achievement Standard 90470 - Examine Individual or Group Identity in an Historical Setting, in an Essay (Version 1). Accessed December 5, 2011. http://www.nzqa.govt.nz/nqfdocs/ncearesource/achievements/2004/as90470.pdf.

New Zealand Qualifications Authority. Unit standard 5821 - Define and Plan an Historical Investigation under Supervision. Accessed December 5, 2011. http://www.nzqa.govt.nz/nqfdocs/units/pdf/5821.pdf.

New Zealand Qualifications Authority. Unit standard 5822 - Examine Historical Sources. Accessed December 5, 2011. http://www.nzqa.govt.nz/nqfdocs/units/pdf/5822.pdf.

New Zealand Qualifications Authority. Unit standard 5823 - Communicate Historical Information in an Essay and Another Mode. Accessed December 5, 2011. http://www.nzqa.govt.nz/nqfdocs/units/pdf/5823.pdf.

University of Cambridge International Examinations. General Certificate of Education, Advanced Subsidiary and Advanced Level, Paper 1 - Modern European History, 17981939 (May/June 2006).

\section{Newsletter, Newspaper and Magazine Articles}

Bassett, J. "National History Curriculum Committee." New Zealand Historical Association Newsletter, November, 1982.

Bennett, J. "Another Edifice Built on Fallacies." The Press, November 24, 1999.

Braithwaite, R. "Tomorrow's Schools and History." New Zealand Historical Association Newsletter, 2, 1988.

“Cabinet to Discuss Teachers' Concerns." Wanganui Chronicle, April 1, 1996. 
"Careers for History Students." New Zealand Historical Association News, December, 1980.

Chapple, G. "Elite Schools Waylay a Revolution." New Zealand Listener, July 23, 1996.

Department of Education. History Newsletter 6, 1984.

"Externals are here to stay." Sunday Star Times, December 15, 1996.

Gerritson, J. "New Assessment System Announced." NZ Education Review, November 4, 1998.

Ginever, N. "A Historian's Peek into the Search for Administrative Excellence." New Zealand Historical Association Newsletter, 3, 1988.

Lineham, P. "National History Curriculum Committee Report." New Zealand Historical Association Newsletter, 1, 1985, 8-9.

“Link Between School Results Criticised.” The Dominion, April 28, 1992.

Marshall, N. "The National History Curriculum Committee: A Phoenix or a Dead Duck?" Wellington Area History Teachers' Association Newsletter, November, 1984, 3.

"NZHTA Survey 2002 - Results." New Zealand History Teachers' Association Journal, November, 2002, 32-38.

“Parents not Convinced by Internal Assessment." Christchurch Star, 5th November, 1986.

"Quest for Excellence." New Zealand Herald, March 3, 1997.

"School Head Slams System." Taranaki Herald, November 11, 1987.

"Schools Discuss Breakaway Exam System." The New Zealand Herald, December 9, 1999.

"Survey of Needs - Results of February 1983 Survey." Department of Education History Newsletter 5, 1983.

"Statement of Hon M L Wellington for the New Zealand Times." New Zealand Times, March 18, 1984.

“Wanganui Grading Debacle Revealed in Parliament.” Wanganui Chronicle, May 1, 1987. 


\section{Radio Transcripts}

1ZB Radio Interview Transcript. Wednesday November 30, 1994.

Radio Liberty 'New Freeland’ Interview Transcript. July 10, 1995.

\section{Official Publications}

Department of Education. The Curriculum Review - Report of the Committee to Review the Curriculum in Schools. Wellington: Department of Education, 1987.

Department of Education. First Report of the Committee of Inquiry into Curriculum, Assessment and Qualifications in Forms 5 to 7: Implications of the Removal of the University Entrance Examination from Form 6. Wellington: Department of Education, 1985.

Department of Education. Form Six History - A Forms Five to Seven History Resource. Wellington: Department of Education, 1989.

Department of Education. Learning and Achieving - Second Report of the Committee of Inquiry into Curriculum, Assessment, and Qualifications in Forms 5 to 7. Wellington: Department of Education, 1986.

Department of Education. Report of an Investigation into Teacher Panel Moderation and the use of Grade Related Criteria Associated with Sixth Form Certificate Geography 1987-1988. Wellington: Department of Education, 1989.

Department of Education. Sixth Form Certificate History Course Statement. Wellington: Department of Education, 1988.

Hawke, G. Report on Post Compulsory Education and Training in New Zealand. Wellington: Government Printer, 1988.

Māori Affairs Parliamentary Select Committee. Inquiry into Grade Allocation for Sixth Form Certificate Māori. Wellington: Parliamentary Services, 1998.

Ministry of Education. History Form 5 to 7 Syllabus for Schools. Wellington: Learning Media, 1989.

Ministry of Education. NCEA Level Two Professional Development Programme Teacher Handbook - History, 2002-2003. Wellington: Ministry of Education, 2002.

Ministry of Education. The New Zealand Curriculum. Wellington: Learning Media, 2007. 
Ministry of Education. New Zealand Curriculum Framework. Wellington: Learning Media, 1993.

Ministry of Education. Social Studies in the New Zealand Curriculum. Wellington: Learning Media, 1997.

New Zealand Qualification Authority. History Unit Standards Assessment Guide. Wellington: NZQA, 1996.

New Zealand Qualifications Authority, Sixth Form Certificate History Course Statement. Wellington: NZQA, 1990.

Taskforce to Review Education Administration. Administrating for Excellence: Effective Administration in Education. Wellington: Government Printer, 1988.

University of Chicago. The Chicago Manual of Style - Sixteenth Edition. Chicago: The University of Chicago Press, 2010.

University Grants Committee. Report of the University Entrance Board for the Year 1985. Wellington: University Grants Committee Publications, 1986.

University Entrance Board, University Entrance History Examination Prescription 1985. Wellington: University Entrance Board, 1985.

Books, Chapters in Books, Academic Journal Articles and Published Research

Apple, M. "Curriculum Planning - Content, Form and the Politics of Accountability." In The Sage Handbook of Curriculum and Instruction, edited by F. Connelly, 25-41. Thousand Oaks, California: Sage Publications, 2008.

Apple, M. Education and Power. New York: Routledge, 1995.

Apple, M. Official Knowledge: Democratic Education in a Conservative Age. London: Routledge, 1993.

Barbour, R. Introducing Qualitative Research: A Student Guide to the Craft of Doing Qualitative Research. London: Sage, 2008.

Berg, B. Qualitative Research Methods in the Social Sciences. Boston: Pearson Education, 2007. 
Bernstein, B. "On the Classification and Framing of Educational Knowledge." In Knowledge and Control, edited by M. Young, 47-69. London: Collier-MacMillan, 1971.

Burr, V. An Introduction to Social Constructionism. London: Routledge, 1995.

Codd, J., R. Harker, and R. Nash, eds. Political Issues in New Zealand Education. Palmerston North: Dunmore Press, 1985.

Cornbleth, C. Curriculum in Context. Basingstoke: Falmer Press, 1990.

Deng, Z., and A. Luke. "Subject Matter - Defining and Theorizing School Subjects." In Sage Handbook of Curriculum and Instruction, edited by F. Connelly, 66-87. Thousand Oaks, California: Sage Publications, 2008.

Fontana, A., and J. Frey. "The Interview: From Neutral Stance to Political Involvement." In Sage Handbook of Qualitative Research, Third Edition, edited by N. Denzin and Y. Lincoln, 695-727. Thousand Oaks, California: Sage Publications, 2005.

Fountain, G. "Caught in Between: How the Scientific Management of Education made History History." Curriculum Matters 4 (2008): 134-46.

Gillham, B. The Research Interview. London: Continuum, 2000.

Guyver, R. "History Curricula in England and New Zealand: Identity, Belonging, and the Case for Valuing an Historical Perspective," Escalate (2008). Accessed August 6, 2010, http://escalate.ac.uk/4555.

Hargreaves, A. Curriculum and Assessment Reform. Buckingham: Open University Press, 1989.

Hunter, P., and B. Farthing. Talking History: Teachers' Perceptions of "Their" Curriculum in the Context of History in the New Zealand Curriculum. Hamilton: Wilf Malcolm Institute of Educational Research, 2004.

King, M. Being Pakeha. Auckland: Hodder \& Stoughton, 1985.

Lee, P., and R. Ashby. "Progression in Historical Understanding Among Students Ages 7-14." In Teaching and Learning and Knowing History, edited by P. Sexias, P. Stearns and S. Wineburg, 199-222. New York: New York University Press, 2000.

Low-Beer, A. "The Eclipse of History in New Zealand Schools." New Zealand Journal of Educational Studies 21 (1986): 113-22. 
McGee, C. Teachers and Curriculum Decision-Making. Palmerston North: The Dunmore Press, 1997.

McCulloch, G. Documentary Research in Education. London: Routledge Falmer, 2004.

McCulloch, G., G. Helsby and P. Knight. The Politics of Professionalism. London: Continuum, 2000.

McCulloch, G., and W. Richardson. Historical Research in Education Settings. Philadelphia: Open University, 2000.

McQueen, H. “Once Were Curriculum Developers." Curriculum Matters 2 (2006): 182-94.

Meleisea, M. The Making of Modern Samoa. Suva: Institute of Pacific Studies of the University of the South Pacific, 1987.

Morse, J., and L. Richards. Read me First for a User's Guide to Qualitative Methods. Thousand Oaks, California: Sage Publications, 2000.

Murdoch, J. The High Schools of New Zealand - A Critical Survey. Wellington: New Zealand Council of Educational Research, 1943.

New Zealand Post Primary Teachers' Association. Education in Change: Report of the Curriculum Review Group. Auckland: Longman Paul, 1969.

O'Neill, A., J. Clark and R. Openshaw. "Mapping the Field: An Introduction to Curriculum Politics in Aotearoa/New Zealand." In Reshaping Culture, Knowledge and Learning: Policy and Content in the New Zealand Curriculum Framework, edited by A. O'Neill, J. Clark and R. Openshaw, 25-46. Palmerston North: Dunmore Press, 2004.

O’Neill, J. "Change and Constancy: Half a Century of Secondary Schooling in New Zealand." History of Education Review 33 (1, 2004): 44-59.

Openshaw, R. Reforming New Zealand Secondary Education - The Picot Report and The Road to Radical Reform. New York: Palm Grove MacMillan, 2009.

Partington, G. "Social Studies in The New Zealand Curriculum." In New Horizons for New Zealand Social Studies, edited by P.Benson and R. Openshaw, 83-102. Palmerston North: ERDC Press, 1998. 
Phillips, R. History Teaching, Nationhood and the State: A Study in Educational Politics. London: Cassell, 1998.

Roberts, P. "The Politics of Curriculum Reform in New Zealand," Curriculum Studies (6, 1998): 29-46.

Sexias, P. "Mapping the Terrain of Historical Significance," Social Education 61 (1, 1997): 2227.

Sheehan, M. "'Little is Taught or Learned in Schools': Debates over the Place of History in the New Zealand School Curriculum." In History Wars in the Classroom: A Global Perspective, edited by R. Guyver and T. Taylor. Charlotte, North Carolina: Information Age Publishing, in press.

Sheehan, M. "The Place of New Zealand in the New Zealand History Curriculum," Journal of Curriculum Studies 42 (5, 2010): 671-91.

Sheehan, M. "A Question of Bias? Politics, Assessment and the New Zealand History Curriculum," History of Education Review 40 (2, 2011): 176-88.

Shemilt, D. "The Devil's Locomotive." History and Theory 22 (4, 1983): 1-18.

Shuker, R. "Cleo in the Curriculum: The Place of History as a Secondary School Subject." In The School Curriculum in New Zealand: History, Theory, Policy and Practice, edited by G. McCulloch, 185-202. Palmerston North: Dunmore Press, 1992.

Silverman, D., and A. Marvasti. Doing Qualitative Research - A Comprehensive Guide. Thousand Oaks, California: Sage Publications, 2008.

Sinclair, K. A Destiny Apart: New Zealand's Search for National Identity. Wellington: Allen \& Unwin, 1986.

Stake, R. "Qualitative Case Studies." In Sage Handbook of Qualitative Research, Third Edition, edited by N. Denzin and Y. Lincoln, 442-66. Thousand Oaks, California: Sage Publications, 2005.

Stenson, M. "History in New Zealand Schools." New Zealand Journal of History, 24 (1990), 170-81.

Taba, H. Curriculum Development: Theory and Practice. New York: Harcourt Brace and World, 1962. 
Wood, J. Vietnam and the Indochina Conflict. Auckland: MacMillan, 1990.

Yin, R. Case Study Research: Design and Methods. Thousand Oaks, California: Sage, 1994.

\section{Theses and Unpublished Papers}

Bargas, I. "God Defend New Zealand or Save the Kings and Queens? An Examination of the Status of New Zealand History at Year Thirteen." Master's thesis, Victoria University of Wellington, 2005.

Derbyshire, A. "'Anyone's but our own' - The Teaching of New Zealand History in New Zealand Schools." Master's thesis, University of Auckland, 2004.

Manning, R. "The Status of Te Atiawa Histories in the Port Nicholson Block Secondary Schools and the Possible Application of Place-Based Education Models." PhD diss., Victoria University of Wellington, 2009.

Sheehan, M. "Defending the High Ground: The Transformation of History into a Senior School Subject in the Late Twentieth Century - A New Zealand Curriculum Debate." PhD Diss., Massey University, 2008.

Shuker, R. "History in the New Zealand Secondary School: A Study in Aspects of Curriculum Development." PhD Diss., Victoria University of Wellington, 1978.

Wood, D. "The Political Origins of the New Zealand Curriculum Framework." Unpublished paper, Victoria University of Wellington, 1993.

\section{Presentations}

Fountain, G. "Looking Back to Move Forward." SocCon - Inquiring Minds, Active Citizens, Wellington, July 19, 2011. 